UNIVERSIDADE DE SÃO PAULO

FACULDADE DE ECONOMIA, ADMINISTRAÇÃO E CONTABILIDADE DEPARTAMENTO DE ADMINISTRAÇÃO

PROGRAMA DE MESTRADO PROFISSIONAL EM EMPREENDEDORISMO

LEONARDO FRANÇA CARNEIRO

A construção de um negócio inclusivo aplicado à atividade de recrutamento e seleção 
Prof. Dr. Vahan Agopyan

Reitor da Universidade de São Paulo

Prof. Dr. Adalberto Américo Fischmann

Diretor da Faculdade de Economia, Administração e Contabilidade

Prof. Dr. Moacir de Miranda de Oliveira Jr.

Chefe do Departamento de Administração

Prof. Dr. Marcelo Caldeira Pedroso

Coordenador do Programa de Mestrado Profissional em Empreendedorismo 


\section{A construção de um negócio inclusivo aplicado à atividade de recrutamento e seleção}

Dissertação ao título de Mestre em Administração do Programa de Mestrado Profissional em Empreendedorismo do Departamento de Administração da Faculdade de Economia, Administração e Contabilidade da Universidade de São Paulo.

Área de Concentração: Empreendedorismo

Orientadora: Prof. ${ }^{\text {a }}$ Dr. ${ }^{\text {a }}$ Graziella Comini

São Paulo 
FICHA CATALOGRÁFICA

Elaborada por Rafael Mielli Rodrigues - CRB-8/7286 Seção de Processamento Técnico do SBD/FEA/USP

\section{Carneiro, Leonardo França}

A construção de um negócio inclusivo aplicado à atividade de recrutamento e seleção / Leonardo França Carneiro - São Paulo, 2018.

$131 \mathrm{p}$.

Dissertação (Mestrado) - Universidade de São Paulo, 2018.

Orientador: Graziella Maria Comini.

1. Empreendedorismo social 2. Negócio inclusivo 3. Valor compartiIhado 4. Recrutamento e seleção I. Universidade de São Paulo. Faculdade de Economia, Administração e Contabilidade. II. Título. 
Ao João e à sua geração, que possam repensar nossa sociedade e nossos caminhos. 



\section{AGRADECIMENTOS}

Um agradecimento especial à minha mãe, Eliana, incansável incentivadora da pesquisa, e à minha esposa, Marília, pelo companheirismo, ensinamentos acadêmicos e compreensão nas ausências durante toda a jornada do projeto.

À minha orientadora, Prof. ${ }^{a}$ Dr. ${ }^{a}$ Graziella Comini, pela notável orientação e, acima de tudo, pelos amplos e precisos ensinamentos sobre negócios de impacto.

Aos meus sócios, Vinícius Rocha, Luiz Ponce e Marcelo Fugimoto, por sonharem o meu sonho.

Ao Prof. Dr. Marcelo Pedroso, pela sua dedicação na transmissão do conhecimento e inegável contribuição à pesquisa.

Aos colegas da terceira turma do Mestrado Profissional em Empreendedorismo da FEA-USP, pelo apoio mútuo e contribuições dentro e fora da academia para o sucesso do projeto.

Ao Prof. Dr. Martinho de Almeida, pelo constante apoio ao tema da pesquisa e aconselhamento na estruturação do projeto. 



\section{RESUMO}

CARNEIRO, Leonardo França. A construção de um negócio inclusivo aplicado à atividade de recrutamento e seleção, 2018. 130 f. Dissertação (Mestrado Profissional em Empreendedorismo) - Departamento de Administração da Faculdade de Economia, Administração e Contabilidade da Universidade de São Paulo, 2018.

O modelo econômico capitalista é constantemente questionado quanto à sua débil capacidade de distribuir riqueza e, por consequência, linhas de pensamento com modelos alternativos são frequentemente propostas. Uma linha de pensamento que tem ganhado notoriedade toma o sistema capitalista atual como ponto de partida, não propõe uma ruptura, mas uma evolução do seu conceito ao inserir premissas de impacto social. Nesse modelo, algumas definições de negócios têm sido cunhadas, como negócios sociais, negócios inclusivos e empreendimentos sociais. Este projeto tomou como ponto de partida a experiência vivida em uma startup de recrutamento de pessoal para posições operacionais, a ADS, e seu plano de transformação do modelo de negócio atual para um negócio inclusivo, onde buscava não apenas inserir a temática responsabilidade social em suas ações mas inclúi-la em sua atividade central como forma de solução a um problema operacional do empreendimento. Para atender ao objetivo da empresa, o estudo, uma pesquisa-ação, propôs e testou um modelo de negócio inclusivo no mercado de recrutamento e seleção. Para tanto, percorreu as etapas de: (1) investigação (análise do caso de negócio inclusivo da Danone Kiteiras e execução de teste); (2) proposição (planejamento do negócio); (3) ação (execução do plano de negócio ao longo de onze meses). O estudo revelou, ainda na primeira etapa da pesquisa, a necessidade de romper com o modelo de negócio da ADS, uma consultoria de recrutamento e seleção, e criar uma plataforma que conectasse empregadores e mães, que fariam o trabalho de recrutar e selecionar profissionais em suas comunidades. Nesse novo modelo, a empresa nascente (Kunla) assumiu a responsabilidade de capacitar as mães para entregarem o serviço de recrutamento e seleção (estruturar a oferta) e, ainda, vender o serviço dessas mulheres a empresas (gerar demanda). Ao final dos onze ciclos de execução do plano de negócio, a pesquisa conseguiu viabilizar um modelo operacional inclusivo para a atividade de recrutamento e seleção, dando condições à empresa de seguir adiante para a etapa de comercialização massiva do serviço.

Palavras-chave: Valor Compartilhado. Negócios Inclusivos. Recrutamento e Seleção. 


\begin{abstract}
CARNEIRO, Leonardo França. Building a socially inclusive business applied do recruitment and selection industry, 2018. 130 f. Dissertação (Mestrado Profissional em Empreendedorismo) - Departamento de Administração da Faculdade de Economia, Administração e Contabilidade da Universidade de São Paulo, 2018.
\end{abstract}

The capitalist economic model is constantly questioned about its weak ability to distribute wealth and, as consequence, lines of thought with alternative models are often proposed. A line of thought that has gained notoriety takes the current capitalist system as a starting point, does not propose a rupture, but an evolution of its concept by inserting assumptions of social impact in it. In this model, some business definitions have been minted, such as social business, socially inclusive business, and social enterprises. This project took as its starting point the experience of a staff recruitment startup focused on operational positions, ADS, and its plan to transform the current business model into a socially inclusive business, where it sought not only to insert the social responsibility theme in its actions, but include it in its central activity as a way of solving an operational problem of the enterprise. To meet the company's goal, the study, an action-researched, proposed and tested a socially inclusive business model in the recruitment and selection market. To do so, it went through the steps of (1) investigation (analysis of Danone's Kiteiras's socially inclusive business case and testing); (2) proposition (business planning); (3) action (execution of the business plan over eleven months). The study also revealed the need to break up with the ADS business model, a recruitment and selection consultancy, and create a platform that would connect employers and mothers, who would do the job of recruiting and selecting professionals in their communities. In this new model, the startup company (Kunla) assumed the responsibility of capacitating the mothers in order to deliver the recruitment and selection service (structuring the offer) and also selling of these women's services to companies (generate demand). By the end of the eleven cycles executing the business plan, the research succeeded in building an inclusive operational model for the recruitment and selection activity, enabling the company to move forward to mass marketing the service.

Keywords: Shared value. Socially inclusive business. Recruitment and selection. 


\section{LISTA DE FIGURAS}

Figura 1 - Criação, entrega e captura de valor...................................................................25

Figura 2 - Quatro dimensões estratégicas por Osterwalder e Pigneur (2010).........................31

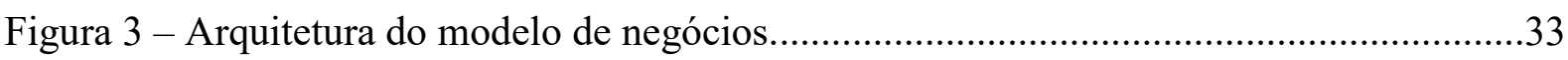

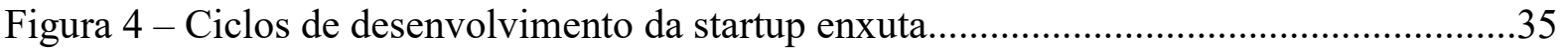

Figura 5 - Estrutura do método de pesquisa-ação..................................................................36

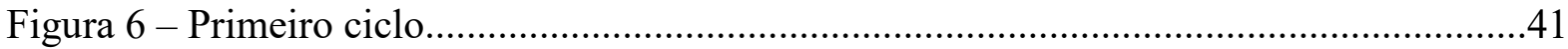

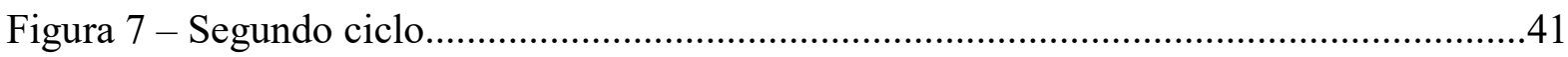

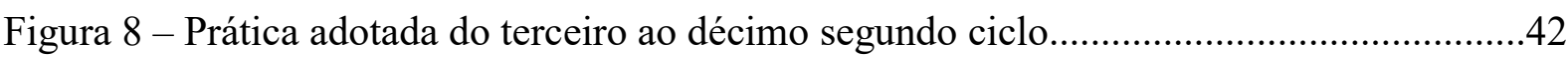

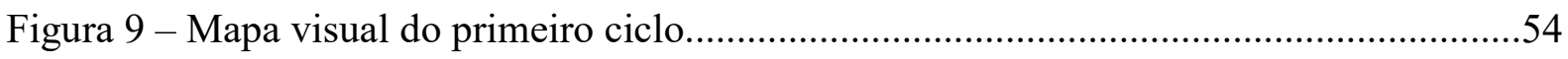

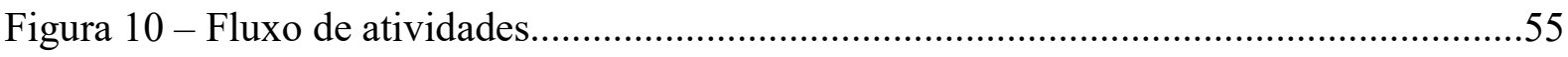

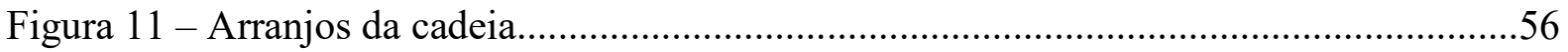

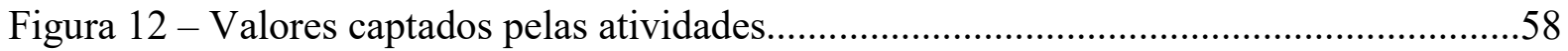

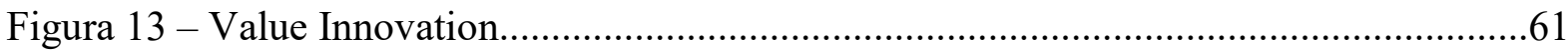

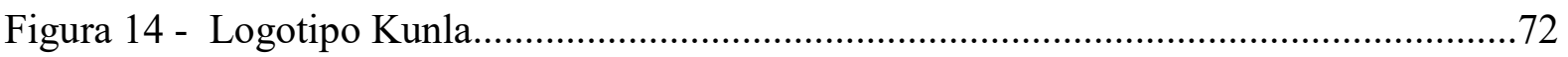

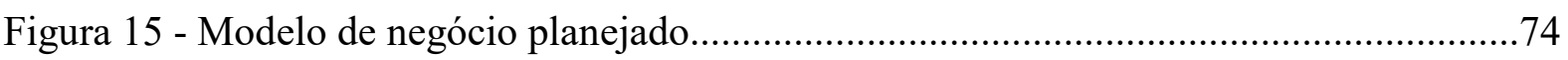

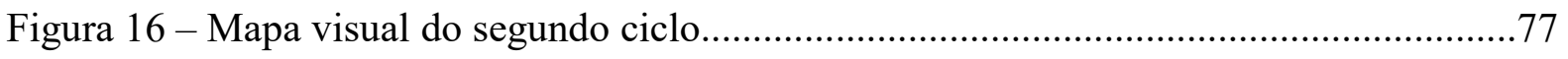

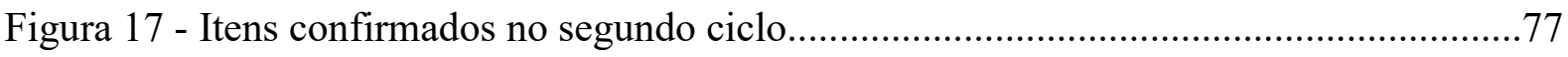

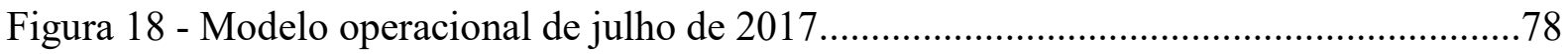

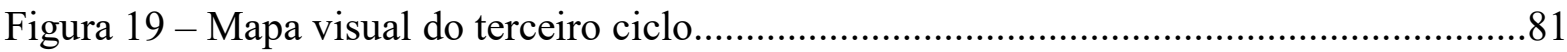

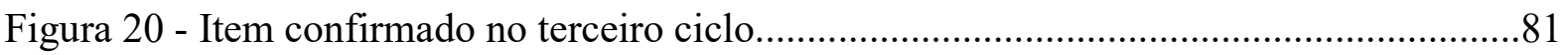

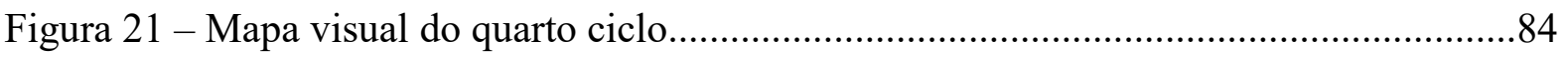

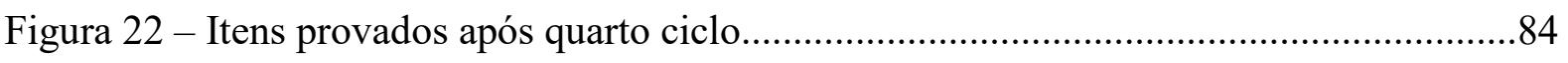

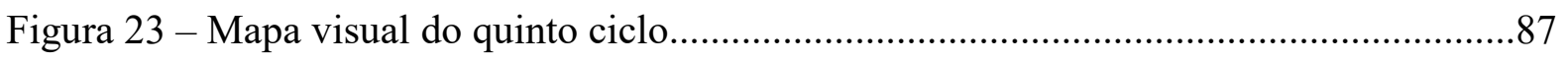

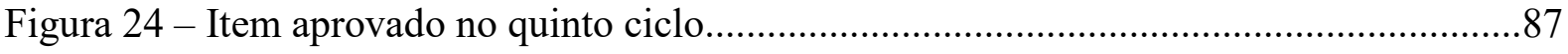

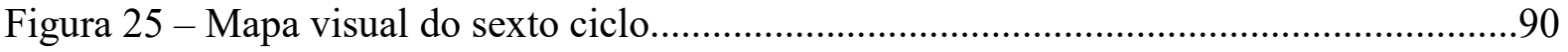

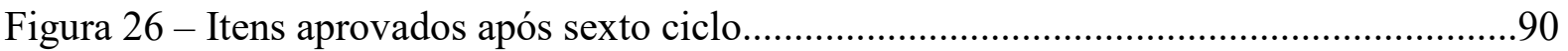

Figura 27 - Segunda revisão do modelo de operação............................................................91

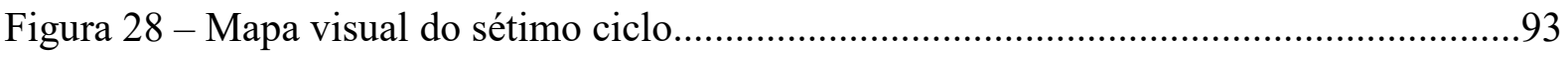

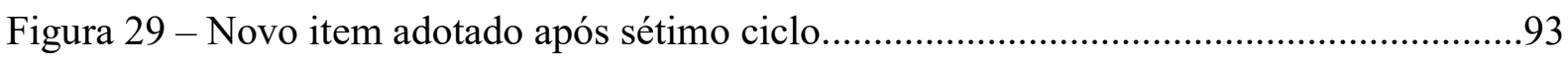

Figura 30 - Terceira revisão do modelo de operação...........................................................95

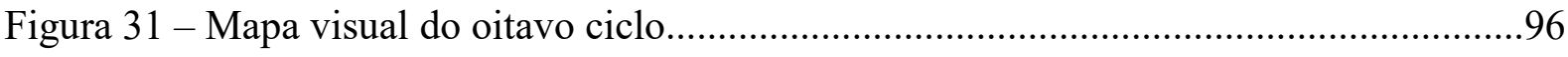




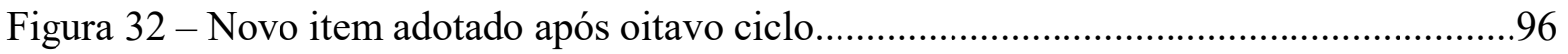

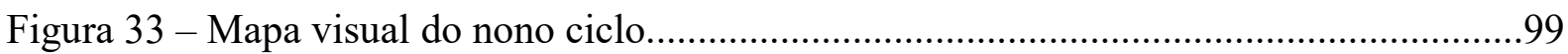

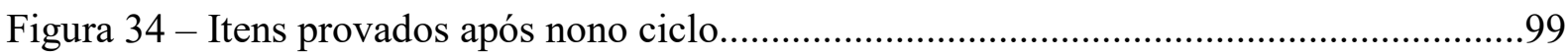

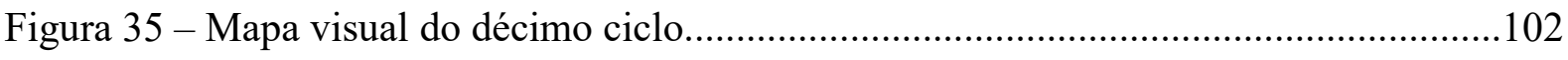

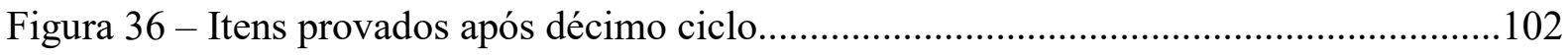

Figura 37 - Mapa visual do décimo primeiro ciclo................................................................104

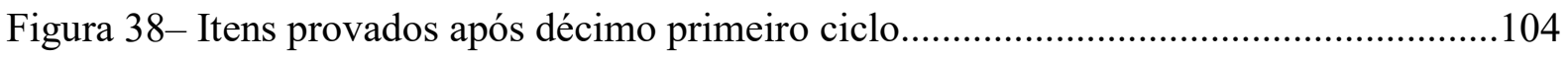

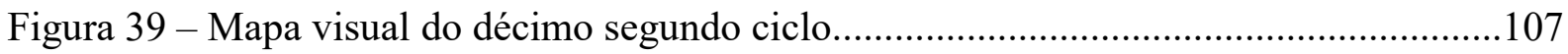

Figura 40 - Modelo de negócio ao término do décimo segundo ciclo..................................107

Figura 41 - Fluxo de validação de dimensões.....................................................................115 


\section{LISTA DE TABELAS}

Tabela 1 - Tabela comparativa entre negócios sociais e negócios inclusivos. .......................27

Tabela 2 - Elementos presentes em arquiteturas de modelos de negócios sociais ...................34

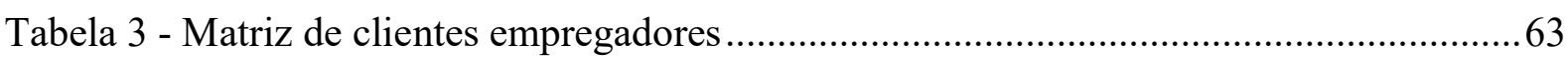

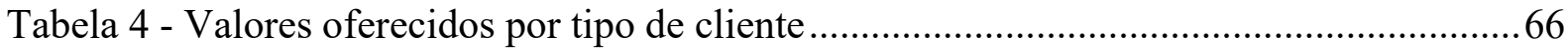




\section{LISTA DE SIGLAS}

AR

Agente de Recrutamento

BID

Banco Interamericano de Desenvolvimento

BOP

Base Of the Piramid

$\mathrm{CC}$

Cliente de Consultoria

MGE

Médias e Grandes Empresas

MPR

Micro e Pequenas Empresas

ONG

Organização Não Governamental

PCD

Pessoa com Deficiência

PDA

Programa de Desenvolvimento de Área

$\mathrm{PF}$

Pessoa Física

$\mathrm{R} \& \mathrm{~S}$

Recrutamento e Seleção

UPR

Usuário de Plataforma de Recrutamento 


\section{SUMÁRIO}

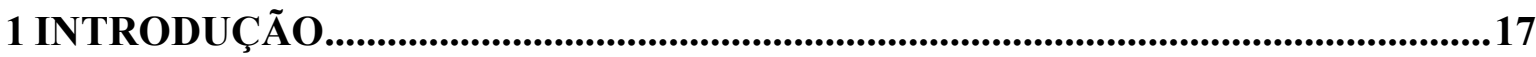

1.1 RELATO DA EXPERIÊNCIA.....................................................................................................18

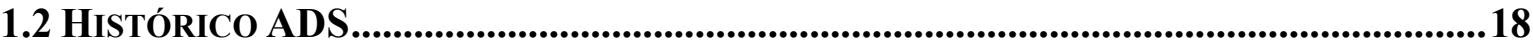

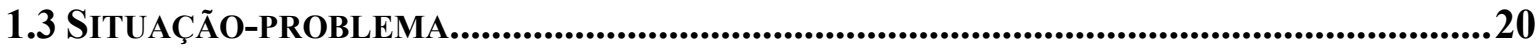

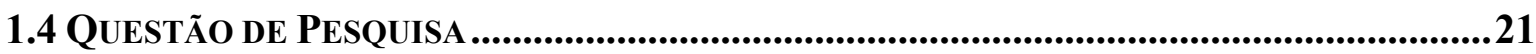

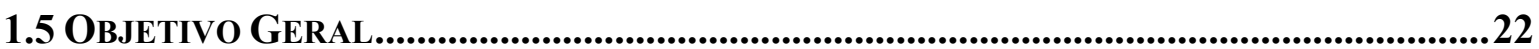

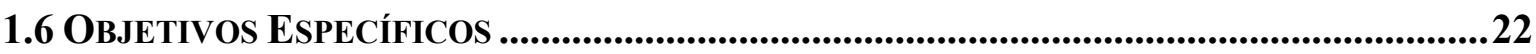

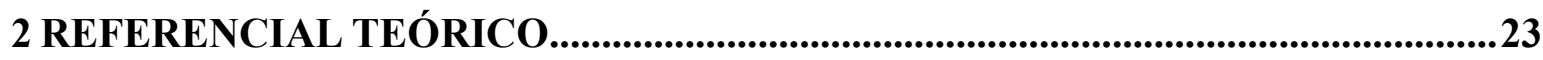

2.1 O CONCEITO DO VALOR COMPARTILHADO......................................................................23

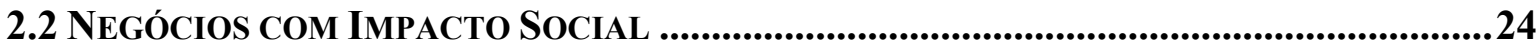

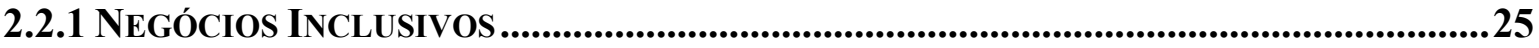

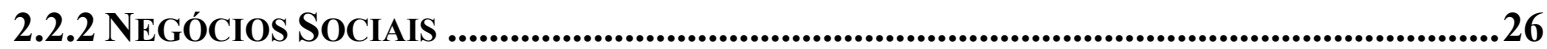

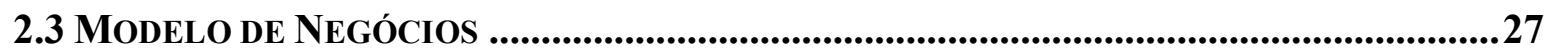

2.4 A Startup EnXuta e a PeSQuisa-AÇÃo ...................................................................35

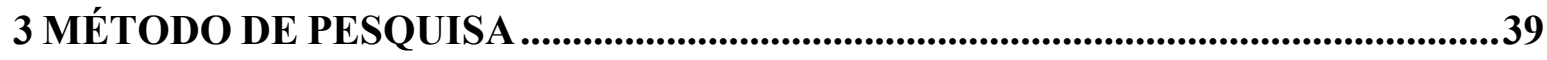

3.1 OS CICLOS DE APRENDIZADO .............................................................................................40

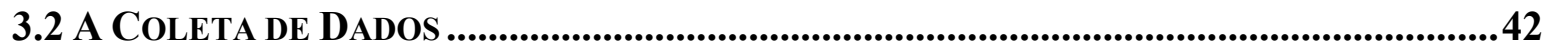

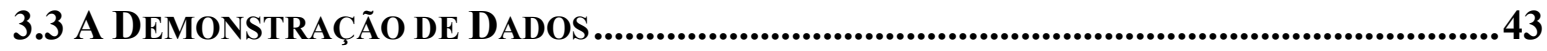

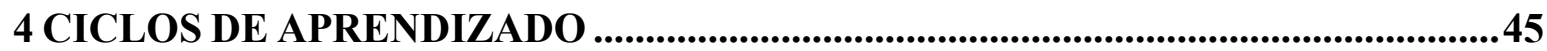

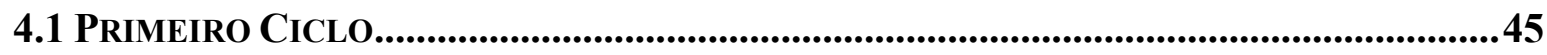

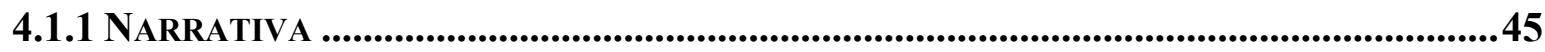

4.1.1.1 ANÁlISE DE CASO DANONE ............................................................................................45

4.1.1.1.1 CONCEITO...........................................................................................................................46

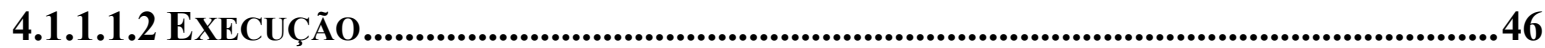

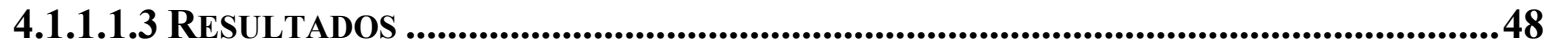

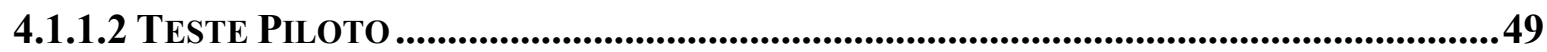

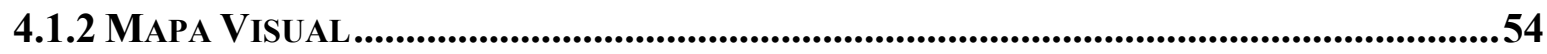

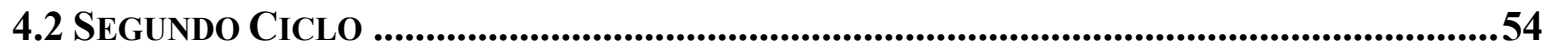

4.2.1 NARRATIVA _............................................................................................................554

4.2.1.1 PlaneJamento do Modelo de Negócio ........................................................54

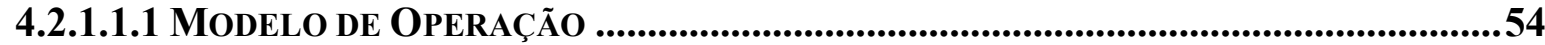

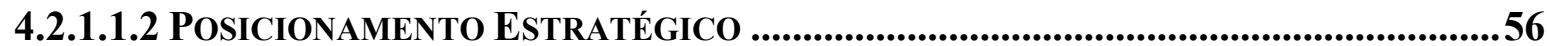




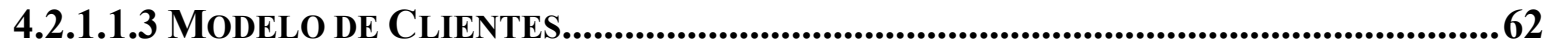

4.2.1.1.4 MODELO ECONÔMICO ..............................................................................................66

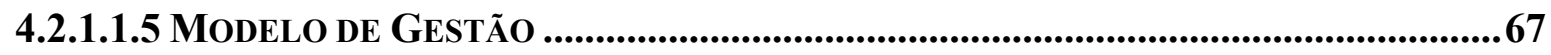

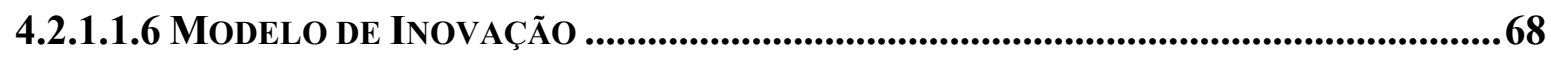

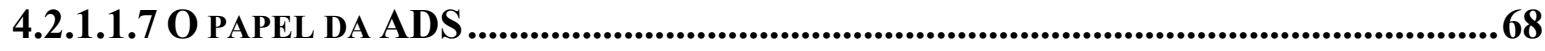

4.2.1.1.8 O DESENVOLVIMENTO DA MARCA .........................................................................

4.2.1.1.9 O DESENVOLVIMENTO DA APLICAÇÃO ....................................................................72

4.2.1.1.10 PRIMEIRO MÊS dE OPERAÇÃo .....................................................................74

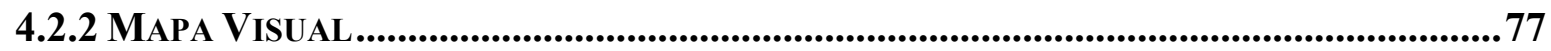

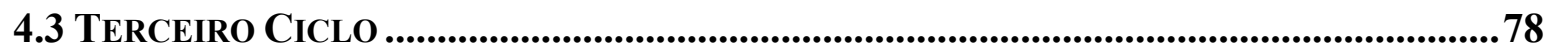

4.3.1 NARRATIVA ..........................................................................................................................78

4.3.2 MAPA VISUAL .........................................................................................................81

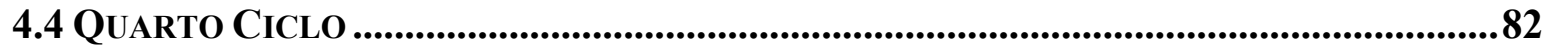

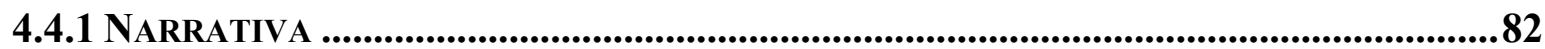

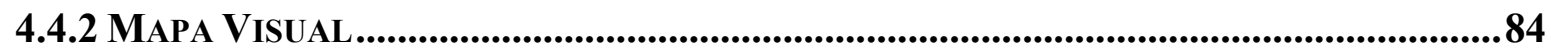

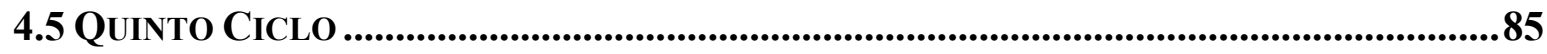

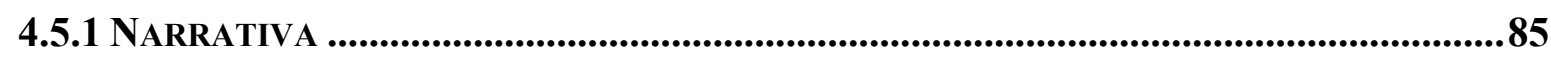

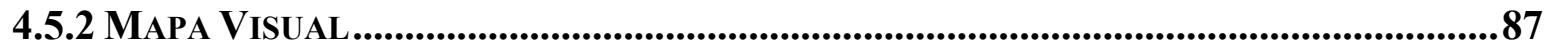

4.6 SEXTO CICLO .......................................................................................................................88

4.6.1 NARRATIVA

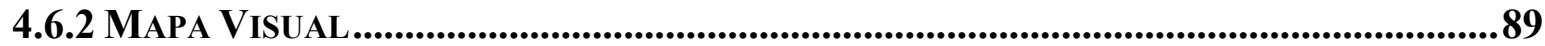

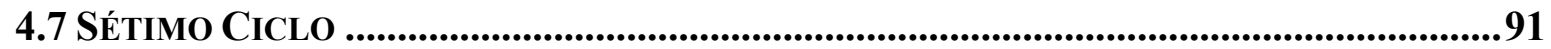

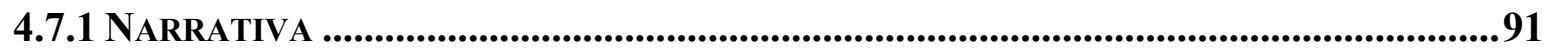

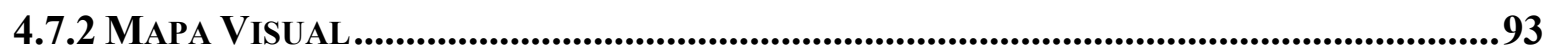

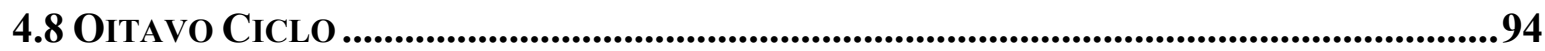

4.8.1 NARRATIVA _...............................................................................................................94

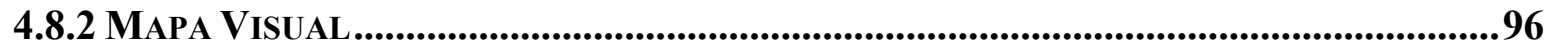

4.9 NONO CICLO .............................................................................................................................97

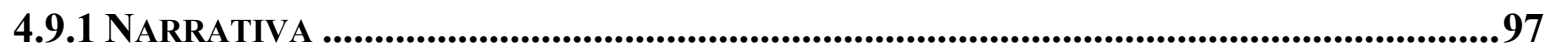

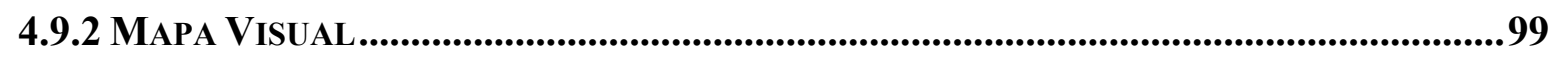

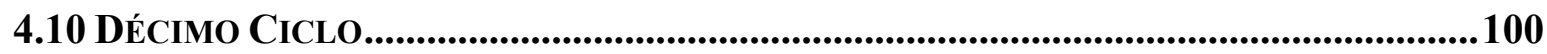

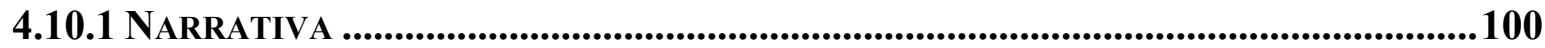

4.10.2 MAPA VISUAL.......................................................................................................... 102

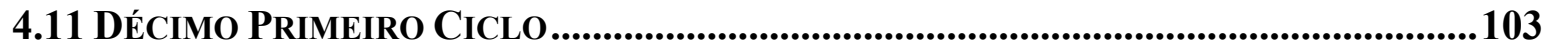




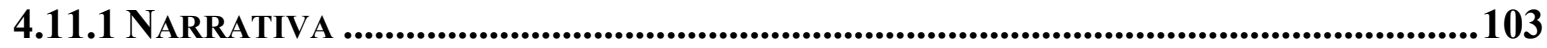

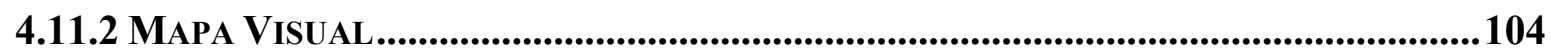

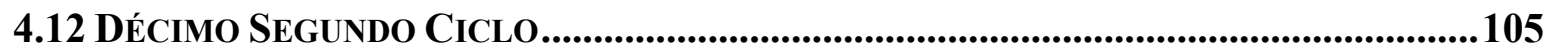

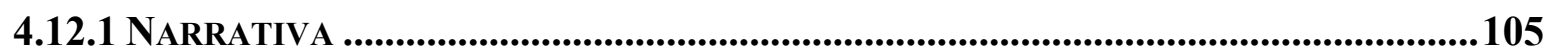

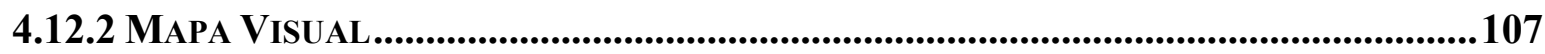

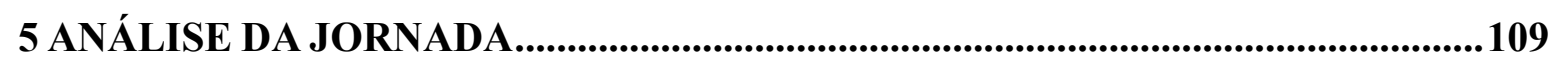

6 CONSIDERAÇÕES FINAIS E RECOMENDAÇÕES ..............................................113

7 LIMITAÇÕES DE PESQUISA ....................................................................................... 117

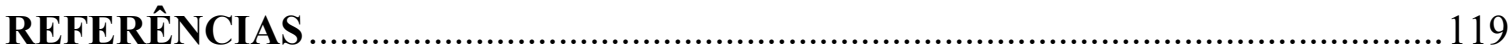

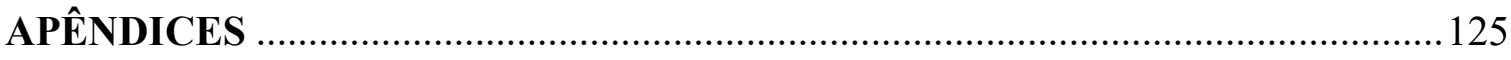

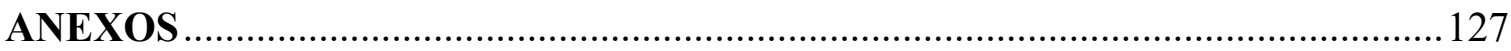





\section{INTRODUÇÃO}

O aumento exponencial de geração e compartilhamento de conteúdo através do novo meio de comunicação, a internet, tem fomentado grandes mudanças sociais no mundo. $\mathrm{O}$ acesso à informação permite ao indivíduo maior consciência sobre o mundo em que está inserido, seus mecanismos de funcionamento e as forças atuantes. A informação gera consciência e a consciência gera pressões e ações sobre os mecanismos e modelos vigentes. Segundo Comini et al. (2014), crescimento econômico, crises financeiras, desigualdades sociais, mudanças climáticas, acelerada alteração na biodiversidade do planeta são temas recorrentes na pauta de discussão da agenda global de governantes, executivos e sociedade em geral. Ainda, ponderam que as empresas, como cerne do modelo capitalista, estão sendo questionadas quanto a seus papéis na solução desses problemas e na geração de impactos sociais positivos e constantes.

Para responder a esses questionamentos, modelos de negócios diversos vêm sendo formulados e testados e distintas nomenclaturas são encontradas na literatura para defini-los, sendo as principais: Negócios com Impacto Social, Negócios Inclusivos, Negócios Sociais e Empreendimentos Sociais. Barki et al. (2013), ao definirem Negócios com Impacto Social, adotam uma abordagem ampla, unindo as organizações pelo impacto social positivo que elas geram, independentemente do modelo financeiro que adotam. Negócios Inclusivos, termo primeiramente utilizado em relatório das Nações Unidas (UNITED NATIONS DEVELOPMENT PROGRAMME, 2008), são definidos por Márquez et al. (2010) como negócios que buscam solucionar ou amenizar uma ou mais questões sociais de maneira financeiramente sustentável, ou seja, de forma que o negócio por si só se perpetue sem auxílio externo. Negócios Sociais possuem definição similar, são estabelecidos como organizações que, por meio de mecanismos de mercado, têm por objetivo resolver problemas sociais com sustentabilidade financeira (COMINI; BARKI; DE AGUIAR, 2012). O termo empreendimentos sociais define empreendimentos que têm como finalidade resolver problemas socioambientais por meio da inovação e cujas ações são capazes de gerar impacto social significativo, produzindo transformação social. Os empreendedores sociais são vistos como pessoas inovadoras, criadoras de novos paradigmas e pioneiros de novas abordagens (DEES, 2001).

Este estudo parte do entendimento de modelos de negócios com impacto social positivo como ponto de partida na busca de uma solução viável e aplicável à empresa que é objeto da pesquisa, a ADS, uma empresa de sociedade limitada e com fins lucrativos. Não há, para os 
sócios, a intenção de mudar a natureza do negócio para uma empresa sem fins lucrativos, o que significa a exclusão do conceito de empreendimentos sociais no modelo de negócio a ser adotado.

\subsection{Relato da Experiência}

A ADS é uma startup de recrutamento e seleção de pessoal para níveis operacionais estabelecida no centro da cidade de São Paulo. Apesar de ter apenas um ano de existência e atuar com recrutamento em um cenário econômico de recessão e demissões, ela conseguiu construir no período uma carteira sólida de grandes clientes, em sua maioria multinacionais. Logo após o início da operação, os sócios da empresa concluíram que ela deveria ter adotado, desde o princípio, algum modelo de operação que contemplasse um impacto social positivo. A natureza desse impacto e sua magnitude nunca foram definidas, assim como também não foi concebido um modelo de operação que o contemplasse. Devido à criticidade do momento (estágio inicial da operação e grande projeto em cliente em andamento), os sócios entenderam que era melhor não fazerem alteração drástica na operação e, portanto, postergaram a adoção de um novo modelo.

Passados dez meses, o conhecimento adquirido sobre o mercado, o amadurecimento dos processos internos e a estabilização da carteira de clientes geraram, aos olhos dos sócios, condições suficientes para a adoção da nova proposta. A diretriz atual do corpo societário é que tal transição seja feita o quanto antes, pois teme-se que o maior amadurecimento da empresa possa gerar barreiras internas para a transição. Duas premissas foram estabelecidas:

i. Ligar o trabalhador ao emprego é a atividade-fim e fator comum ao setor e, portanto, não deve ser entendida como o impacto social a ser buscado, independentemente do quanto essa ação impacte na vida dos profissionais que conquistam uma nova ocupação;

ii. A causa social deve fazer parte do modelo do negócio e estar atrelada à forma como a empresa gera valor.

\subsection{Histórico ADS}

Em janeiro de 2015, quatro sócios de uma pequena empresa de recrutamento executivo tomaram a decisão de investir em um novo negócio: recrutamento e seleção de profissionais para posições operacionais. Esta era a segunda reunião anual de planejamento de uma empresa de apenas dois anos de existência. Outras iniciativas de diversificação de negócios, testadas em 
2014, fracassaram rapidamente por falta de conhecimento do mercado de atuação, baixo capital para investimento e falta de recurso humano adequado. Eram iniciativas de cunho tecnológico e os fracassos levaram o quarteto a um consenso: a melhor opção de diversificação do negócio seria com algum empreendimento que tivesse sinergia com a atividade já existente. A proposta veio naturalmente e foi consensual, pois afinal se tratava de um serviço com sinergia comercial e até mesmo operacional. O principal cliente da primeira empresa, Admos, já sinalizava o interesse em comprar o serviço da segunda empresa, ADS, antes mesmo de sua criação. Na equipe da Admos destacava-se uma jovem profissional com alto potencial, ambição e interesse em empreender junto aos sócios. Dessa forma, duas das três principais variáveis identificadas pelos sócios como críticas para o sucesso da empresa estavam asseguradas: receita inicial e recurso humano chave. Um terceiro item ainda era desconhecido: o mercado de recrutamento e seleção de profissionais para posições operacionais.

Dois meses antes de iniciar-se a operação, a profissional escolhida para liderar o projeto e o sócio majoritário fizeram, em conjunto, baterias de entrevistas com profissionais do mercado. O objetivo das entrevistas era conseguir identificar um profissional com alto potencial para trabalhar na empresa que surgia e, ainda, compreender melhor os processos, as ferramentas, as forças e as debilidades da concorrência. Após mais de quarenta entrevistas chegou-se a algumas conclusões: os processos e ferramentas das empresas eram os mesmos, a atuação era extremamente passiva (anunciavam vagas e aguardavam os candidatos irem até eles), e o quadro de pessoal era pouco qualificado. As suspeitas iniciais de que se tratava de um mercado sem diferenciação e com baixa qualidade no atendimento ao cliente pareciam confirmadas. Foi decidido, portanto, que a nova equipe seria composta por pessoas com alto potencial e sem experiência, e a capacitação da equipe seria feita internamente. Além disso, ficou definido que as redes sociais seriam as principais ferramentas para contato com candidatos, e não as ferramentas de recrutamento convencionais que eram amplamente utilizadas. Uma terceira orientação foi definida pela empresa: ela deveria levar os processos de recrutamento e seleção aos candidatos, e não esperar o oposto. Para isso, os processos de recrutamento deveriam mesclar o modelo de anúncios em redes sociais com o modelo de busca ativa de candidatos do recrutamento executivo. Quanto aos processos de seleção, ficou entendido que a empresa deveria fazê-los por região da cidade de São Paulo, primeiramente com aluguel de salas e, posteriormente, com abertura de escritórios nas regiões.

Em maio de 2015 a operação foi iniciada e incubada na estrutura da Admos. Ao longo dos primeiros meses puderam ser constatados o sucesso de algumas estratégias e o fracasso de 
outras. A estratégia quanto à equipe foi bem-sucedida e a decisão claramente acertada: os processos internos são bastante simples e bem definidos, e com isso a capacitação da equipe se tornou prática e rápida. A execução do processo de seleção por regiões foi muito bem recebida pelos candidatos e, apesar da falta de dados históricos, acredita-se que, devido a isso, houve menos desistências dos candidatos convidados para dinâmicas de grupo e entrevistas. A busca ativa de candidatos se mostrou a principal força perante os concorrentes, a capacidade de entrega de resultados superiores foi expressa pelos clientes e nenhuma conta foi perdida no período. No entanto, os esforços para tornar as redes sociais a principal ferramenta de recrutamento têm gerado poucos resultados. A capacidade da empresa de agrupar um grande número de profissionais em torno da marca ainda é pequena, e a saída foi recorrer às ferramentas tradicionais de recrutamento existentes no mercado, as mesmas utilizadas pela concorrência, e à busca ativa de candidatos. $\mathrm{O}$ resultado final foi positivo, mas o modelo demanda esforço extra e habilidade individual destacada que restringem a capacidade de expansão do serviço. Passados dez meses, chegou-se à conclusão de que os processos internos e a equipe os diferenciavam do mercado, mas as ferramentas os igualavam.

\subsection{Situação-problema}

O desafio de criar um modelo de recrutamento distinto e exclusivo abriu à ADS uma janela de oportunidade para concebê-lo considerando o novo propósito da diretoria de transformar a empresa em um negócio com impacto social.

Nenhuma empresa do setor, nem mesmo as grandes multinacionais, possui ferramenta exclusiva para a captação de profissionais, o que evidencia o tamanho do desafio colocado à ADS. Uma ferramenta, ou novo processo, eficaz e distinta tem potencial para dar à empresa nascente um grande diferencial competitivo frente aos seus concorrentes.

O sócio majoritário, através de sua experiência prática em recrutamento, apontou que o processo de recrutamento é uma atividade de relacionamento e acesso a pessoas; e, para o caso do recrutamento operacional, recrutar demanda relacionamento direto com a base da pirâmide. Ao observar as principais dificuldades enfrentadas no dia a dia da operação na ADS e refletir sobre os modelos e ferramentas de recrutamento vigentes, anúncios online e offline, ficou claro para os sócios que há uma falha de comunicação no mercado de recrutamento operacional. O modelo de anúncio de vagas tem baixo alcance e pouca penetração nas camadas sociais mais baixas, a comunicação escrita com o público-alvo nem sempre é eficaz e a tecnologia envolvida em anúncios online pode ser barreira para uma parcela significativa da população. Com o 
propósito de aproximar a ADS de seu público-alvo e aumentar o alcance de sua comunicação, foi idealizado um novo modelo de recrutamento: recrutamento nas comunidades locais por meio de agentes parceiros. O propósito é assegurar que a mensagem (vaga de emprego) chegue até o destinatário por meio do relacionamento pessoal e da comunicação oral nas comunidades. Para isso foi idealizada a criação de uma rede de agentes de recrutamento na qual os agentes são indivíduos selecionados pela ADS dentro das comunidades para atuarem como parceiros no recrutamento local para as vagas ofertadas pela ADS. Esses agentes receberão financiamento inicial através da ADS para poderem desenvolver sua atividade e serão comissionados pelos resultados individuais alcançados.

O perfil idealizado para os agentes de recrutamento é um grupo social em situação de vulnerabilidade e dependência financeira. Dentro desse perfil, ficou entendido que o grupo de mães com crianças menores de quatro anos será o foco do projeto. É entendimento dos sócios que, nas comunidades, as mães de crianças fora da idade escolar têm a possibilidade de conquista de emprego e renda cerceada ao não terem com quem deixar seus filhos, uma vez que há, no Brasil e em São Paulo, grande déficit de creches públicas. Em 2015 o déficit alcançou três milhões de vagas em todo o país (SENADO FEDERAL, 2015). O modelo proposto pela ADS assegura à mãe a possibilidade de gerar renda própria mediante atividade dentro da própria comunidade, sinergicamente à sua responsabilidade de cuidado maternal. A expectativa é que o modelo propicie o empoderamento das mulheres que participarem do projeto através da independência financeira.

Apesar de a gestão da ADS já ter idealizado o modelo de negócio que a empresa deverá adotar, esse modelo foi idealizado por profissionais sem qualquer experiência em negócios de cunho social. Não há, dentro da empresa, entendimento pleno de modelos de negócios com impacto social, assim como não são conhecidas as melhores práticas para a implementação do modelo e os riscos envolvidos nessa mudança.

Esse cenário coloca para a ADS questionamentos sobre como fazer tal transição, quais os fatores de risco e de sucesso na implementação de um negócio com impacto social e se o modelo imaginado é, de fato, viável.

\subsection{Questão de Pesquisa}


A questão que se coloca é: como entregar o serviço de recrutamento e seleção através de uma rede de mães em comunidades?

\subsection{Objetivo Geral}

O estudo tem por objetivo encontrar o modelo operacional viável para entrega do serviço de recrutamento e seleção através de uma rede de mães em comunidades.

\subsection{Objetivos Específicos}

- Aplicar o método de pesquisa-ação para a busca da solução da questão de pesquisa;

- Analisar fator de sucesso de um negócio inclusivo com similaridades ao negócio proposto;

- Testar a aplicabilidade da ferramenta de análise de modelos de negócios em um cenário de modelagem de um negócio inclusivo;

- Criar uma comunicação próxima com o grupo impactado para construção em conjunto de um modelo operacional viável;

- Registrar o processo de aprendizado fundamentado pela metodologia de pesquisa-ação como contribuição para evolução da aplicação da metodologia em programas de mestrados profissionais. 


\section{REFERENCIAL TEÓRICO}

O modelo econômico capitalista é alvo constante de questionamentos e é crescente a visão de que as empresas são a maior causa dos problemas sociais, ambientais e econômicos no mundo (PORTER; KRAMER, 2011). Segundo Yunus (2007), desde a queda da União Soviética, em 1991, o livre mercado vem conquistando o mundo e os negócios e as transações internacionais passam por crescimentos robustos, mas nem todos estão se beneficiando disso, uma vez que $94 \%$ da riqueza do mundo se concentram em $40 \%$ da população. Os autores convergem na opinião de que os negócios, nos formatos atuais, são responsáveis pelos problemas citados, tanto por falta de restrição e controle sobre as práticas de mercado (YUNUS, 2007) quanto pela visão restrita de lucro no curto prazo presente nas empresas (PORTER; KRAMER, 2011).

A solução desses problemas, no entanto, passa pela evolução do sistema capitalista e não pela sua negação (YUNUS, 2007; PORTER; KRAMER, 2011). O capitalismo tem uma capacidade sem paralelos de prover soluções para as necessidades humanas, aumentar eficiência, criar empregos e gerar riquezas. Utilizando as forças de mercado, os negócios são a mais poderosa força a ser usada na solução dos atuais problemas sociais, econômicos e financeiros (PORTER; KRAMER, 2011).

\subsection{O Conceito do Valor Compartilhado}

O conceito de valor compartilhado pode ser definido como políticas e práticas operacionais que aumentam a competitividade de uma empresa ao mesmo tempo que melhoram as condições sociais e econômicas das comunidades em que operam (PORTER; KRAMER, 2011), ou seja, propiciam o aumento do lucro de um empreendimento através da criação de benefício social por sua atividade central.

Segundo os autores, o conceito é viável porque permite às empresas aumentar o valor da cadeia onde estão inseridas e, dessa forma, aumentar os rendimentos de todos na cadeia que divide esse valor. Essa ideia contrapõe a visão de redistribuição, ou distribuição justa, dos valores da cadeia, pois objetiva aumentar o montante total e não apenas redefinir as partes do todo. Os autores exemplificam as diferenças entre valor compartilhado e redistribuição citando o caso do pequeno agricultor. O conceito de negócio justo (fair trade) propõe maior remuneração ao pequeno produtor rural pela mesma produção, ou seja, uma redistribuição da 
riqueza gerada na cadeia. A perspectiva de valor compartilhado, no entanto, foca-se no desenvolvimento e fortalecimento do pequeno produtor, para que este possa aumentar sua eficiência, produção e qualidade e assegurar sustentabilidade (PORTER; KRAMER, 2011). No segundo caso, a riqueza adicional captada pelo produtor rural é advinda do aumento de sua capacidade de gerar valor, e não da renúncia de parte do lucro pelo seu cliente.

A força do conceito de valor compartilhado e o seu potencial de implementação em larga escala estão na convergência entre interesses individuais e interesses sociais.

Não é filantropia, mas comportamento de interesse pessoal para criar valor econômico ao criar valor social. Se todas as empresas individualmente buscassem valor compartilhado atrelado aos seus negócios em particular, os interesses gerais da sociedade seriam atendidos... Sobrevivência do mais apto ainda prevaleceria, mas a competição de mercado beneficiaria a sociedade de uma forma que foi perdida (PORTER, KRAMER, 2011, p.17, tradução nossa).

O conceito de valor compartilhado é uma forte perspectiva para negócios com impacto social. A possibilidade de aumento de valor criado na cadeia pode viabilizar não somente o aumento dos ganhos daqueles que participam dela como também a ingressão de grupos sociais desassistidos.

\subsection{Negócios com Impacto Social}

Negócios com impacto social têm sido um foco crescente de estudos acadêmicos (ROSOLEN; TISCOSKI; COMINI, 2014), com amplas definições e entendimento sobre a conceituação do tema. A profusão e confusão de terminologias vagamente conceituadas se fazem presentes no terreno do empreendedorismo, levando praticantes e pesquisadores à adoção arbitrária de designações que mais os agradam (GRASSL, 2012). O autor aponta como principal motivo para tamanha discrepância o fato de a evolução do campo ser mais influenciada por gerentes e empreendedores do que por pesquisadores.

Dentre as terminologias mais comumente utilizadas para negócios que visem à geração de valor socioambiental e sustentabilidade financeira, estão negócios sociais, negócios inclusivos e empreendimentos sociais, que assumem definições distintas conforme suas histórias de surgimento (COMINI; BARKI; DE AGUIAR, 2012). Segundo os autores, o termo negócios sociais é norte-americano e tem como influência a visão de que forças de mercado podem atuar na geração de impactos sociais positivos. O conceito europeu de empreendimentos 
sociais traz em si uma parte da cultura europeia e a prática de substituição do Estado pela sociedade civil. Este modelo parte da oferta de serviço social e da integração de grupos desassistidos sem viés financeiro na atividade. O modelo de negócio inclusivo, uma visão de países emergentes, transita entre os dois conceitos previamente descritos e é caracterizado tanto pela sustentabilidade financeira quanto pelo impacto social como objetivo principal.

Este projeto delimita o estudo a Negócios Inclusivos e Negócios Sociais, uma vez que o lucro é e continuará sendo o objetivo do empreendimento.

\subsubsection{Negócios Inclusivos}

Como previamente conceituado, negócios inclusivos, ou socially inclusive business, são empreendimentos que buscam de forma financeiramente sustentável impactar positivamente um grupo social (COMINI; BARKI; DE AGUIAR, 2012). O termo, recentemente cunhado, não tem ampla presença na literatura, porém, conceitos similares, complementares ou até equivalentes, quando unidos, permitem um estudo mais aprofundado sobre o tema. Dois trabalhos são a base conceitual deste estudo trabalho no que tange à conceituação de negócios inclusivos, Socially Inclusive Business (MÁRQUEZ; REFICCO; BERGER, 2010) e Negócios com impacto social no Brasil (BARKI et al., 2013).

Apesar do avanço de pesquisas no campo, ainda há uma importante falta de conhecimento sobre o tema (AUSTIN, Prólogo, 2010). Não poderia ser diferente: o modelo proposto de negócio inclusivo une a premissa capitalista de retorno sobre capital e perpetuidade do patrimônio a conceitos socialistas de melhorias e "empoderamento" de classes sociais necessitadas. A oposição de ideias entre o máximo retorno e a contribuição social talvez seja o maior desafio do conceito: afinal qual seria(m) o(s) modelo(s) que permitiria(m) aumentar o retorno financeiro distribuindo riqueza? A resposta ainda não é clara. A literatura traz estudos e compilações de casos de sucessos, mas uma formulação-padrão ainda não se apresenta viável. Apesar de não haver um modelo-padrão predefinido, há o entendimento de que a viabilidade passa pela ruptura do modelo vigente. Para que um negócio inclusivo seja bem-sucedido, é preciso romper com o paradigma da forma tradicional de fazer negócios; é fundamental inovar e viabilizar novos arranjos institucionais (TEODÓSIO; COMINI, 2012). Um negócio inclusivo, como empreendimento social, identifica e age nas oportunidades para melhorar o sistema, na criação de soluções e na invenção de novas abordagens (SEELOS; MAIR, 2005). É impossível reproduzir um modelo de negócio tradicional apenas adicionando uma dimensão social dentro 
deste (TEODÓSIO; COMINI, 2012).

Segundo Márquez et al. (2010), dentro do universo de estudos sobre o ingresso da base da pirâmide, ou BOP (base of the piramid), em modelos de negócios, há dois conceitos predominantes: o que considera a $B O P$ como consumidora e o que a considera como produtora ou provedora. Os primeiros estudos acadêmicos sobre a $B O P$ focaram-se fundamentalmente no público como um mercado de consumo subaproveitado. Naturalmente foi percebido, com a evolução dos estudos, que fomentar consumo não gera grande impacto em redução de pobreza, uma vez que a pobreza está relacionada com a incapacidade de um indivíduo ou grupo de gerar riqueza (bens, serviços etc.) e é a geração de riqueza que precede o consumo. A caracterização de negócios inclusivos pela inserção de classes sociais mais baixas como clientes ou fornecedores é defendida por Comini et al. (2012), que a utilizam como uma das diferenciações entre os termos negócios sociais, visão norte-americana sobre o tema, e negócios inclusivos, visão de mercados emergentes.

\subsubsection{Negócios Sociais}

Negócio social é um termo comumente utilizado para definir uma companhia com objetivos sociais ou uma unidade de negócio dentro de uma companhia tradicional. Além disso, o termo foi adotado por Organizações Não Governamentais (ONGs) que decidiram adentrar o mercado comercializando bens e serviços (COMINI; BARKI; DE AGUIAR, 2012). Ainda, segundo Comini et al. (2012), a evolução das discussões sobre o tema nos anos 2000 foi acompanhada de uma aproximação entre multinacionais e ONGs, culminando, nos dias atuais, em cocriações de soluções locais de modelos aplicados de negócios sociais.

A concepção de negócios sociais mediante colaboração com ONGs não muda a natureza econômica desses negócios. O modelo de cocriação é, de fato, um meio para atingir o fim: acesso a um mercado consumidor não atendido. Pela descrição de Comini et al. (2012), o viés mercadológico, aliado ao objetivo financeiro, talvez seja a característica mais marcante da definição de negócios sociais. Apesar de Márquez et al. (2007) considerarem que negócios inclusivos podem ser negócios que adotam a BOP tanto como produtora quanto consumidora, Comini et al. (2012) distinguem ambos ao considerar negócios sociais como aqueles que consideram a $B O P$ como consumidores enquanto negócios inclusivos a considera como produtora ou provedora.

Comini et al. (2012), como conclusão da análise de modelos, sintetizam suas características na Tabela 1: 
Tabela 1 - Tabela comparativa entre negócios sociais e negócios inclusivos.

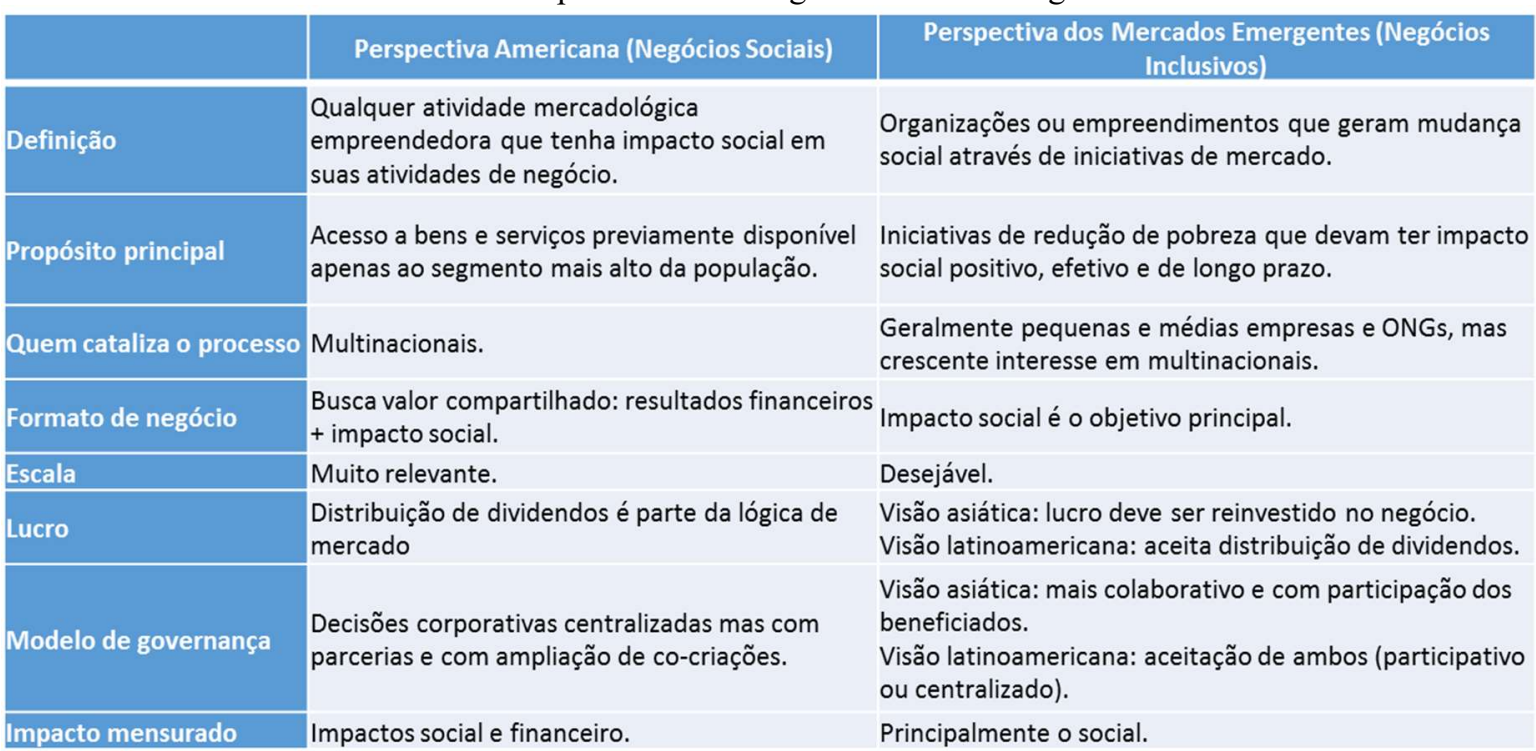

Fonte: Adaptado de Comini et al. (2012).

Comparando-se os modelos representados na Tabela $1 \mathrm{com}$ a perspectiva proposta por Porter e Kramer, é possível notar o alinhamento conceitual entre valor compartilhado e negócios sociais/negócios inclusivos. À parte as divergências conceituais entre negócios sociais e negócios inclusivos, o valor compartilhado se apresenta como possível forma de viabilização da implementação de ambos ao aumentar o valor criado na cadeia em que estão inseridos. A lógica com que esse valor é criado, entregue e capturado é o que define um modelo de negócios (OSTERWALDER; PIGNEUR, 2010).

\subsection{Modelo de Negócios}

O surgimento dos negócios eletrônicos na década de noventa fez com que o termo modelo de negócios ganhasse crescente notoriedade, acompanhado de crescente aumento em publicações acadêmicas (ZOTT; AMIT; MASSA, 2011). O crescente número de publicações foi acompanhado por um conjunto amplo de definições para o termo (AREND, 2013), sendo possível encontrar recorrentes falhas na integração da conceituação de modelos de negócios com os demais conceitos da administração (PEDROSO, 2016).

Pedroso (2016) define modelos de negócios como um modelo conceitual que apoia projeto de negócios de uma organização com o objetivo de entregar valor para seus consumidores e capturar valor para a própria organização. Criação, captura e entrega de valor também foram previamente abordados como componentes de um modelo de negócio, total, ou parcialmente, por Voelpel, Leibold e Tekie (2004), Shafer, Smith e Linder (2005) e Osterwalder 
e Pigneur (2010).

De uma forma concreta, a criação de valor pode ser definida como a soma do valor capturado pela empresa com o valor entregue ao cliente, onde o valor capturado é a diferença entre o valor da transação (preço) e o custo, e o valor entregue é a diferença entre o valor de uso (benefício percebido) e o valor de transação (BESANKO et al, 2012; BOWMAN; AMBROSINI, 2002; MAKADOK; COFF, 2002; PRIEM, 2007). O valor entregue, quando não é nulo, pode ser definido como o excedente do consumidor (BOWMAN; AMBROSINI, 2002), ou seja, é um benefício que excede o valor pago pelo produto ou serviço. A Figura 1 ilustra a lógica de criação, captura e entrega de valor.

Figura 1 - Criação, entrega e captura de valor

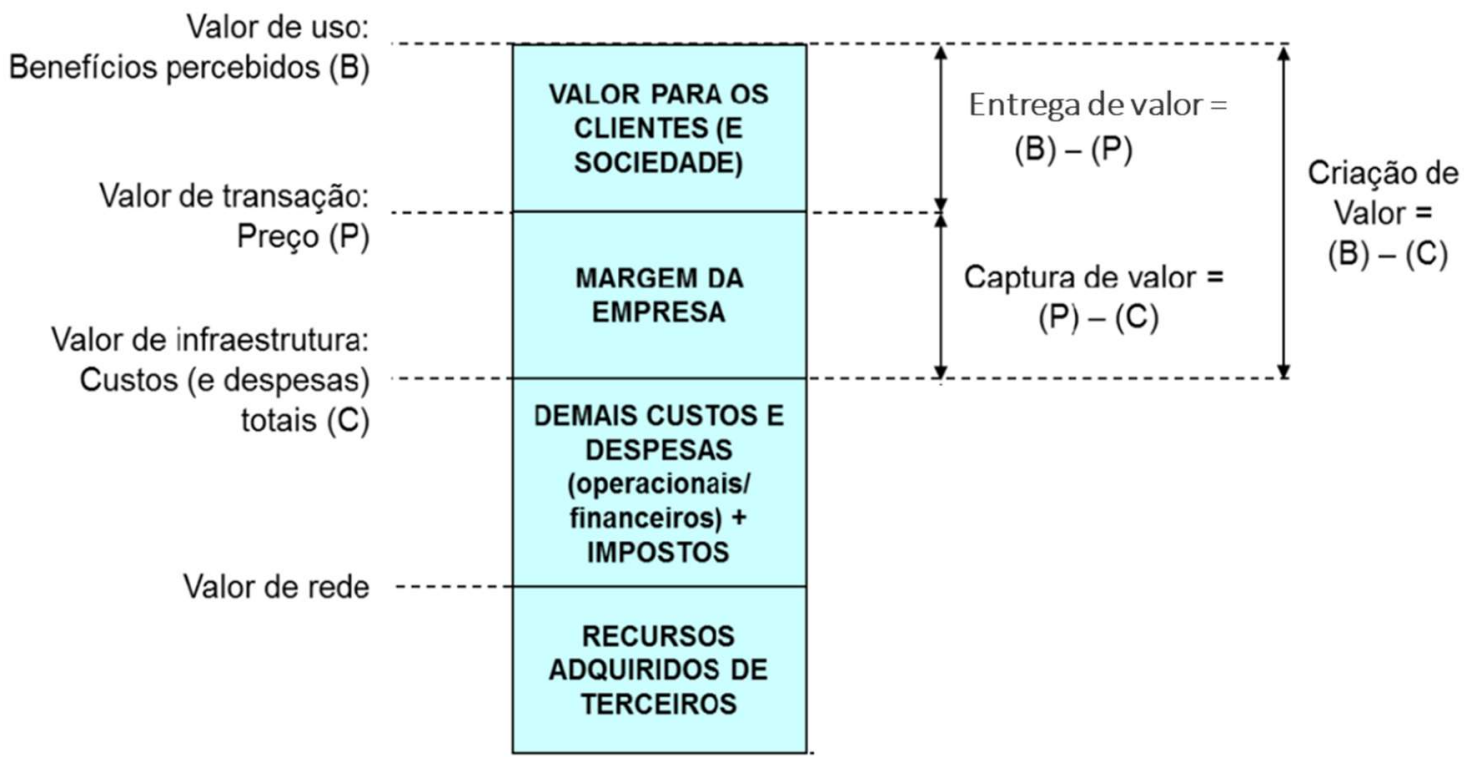

Fonte: Adaptado de Pedroso (2016)

O valor de uso é uma definição subjetiva de quantificação de benefícios percebidos pelo cliente (BOWMAN; AMBROSINI, 2002). Pedroso (2016) considera que o valor de uso pode ser definido por três dimensões de atributos competitivos: atributos funcionais, atributos de conveniência e atributos intangíveis. Segundo o autor, os atributos funcionais denotam o que é entregue (físico e funcional), os atributos de conveniência o como é entregue (disponibilidade, velocidade, acessibilidade etc.) e os atributos intangíveis estão associados às aspirações, percepções de natureza social, emocional, ideológica e institucional.

O valor social, ou o valor entregue à sociedade pelo negócio, pode ser inserido como uma parte do valor de uso (PEDROSO, 2016). Dessa forma a percepção do valor social que o 
produto ou serviço entrega é um atributo intangível que contribui para a construção de um benefício percebido amplificado que pode vir a ser monetizado. $\mathrm{O}$ valor social como parte do valor de uso é convergente com a visão de objetivo único de um empreendimento, o lucro, uma vez que pode ser precificado. No entanto, a adoção de uma visão amplificada sobre o propósito de um empreendimento leva a considerar a criação de valor social como parte do propósito de um negócio (YUNUS, 2007; BORZAGA; DEPEDRI; GALERA, 2012; CLARK JR; BABSON; 2011; GRASSL, 2012), e não somente como um meio para criação de um benefício percebido. A mudança da perspectiva na qual a criação de valor social é vista altera o objetivofim de um empreendimento, que deixa de ser estritamente a maximização do retorno financeiro e passa a ser o equilíbrio entre retorno financeiro e impacto social. Essa dualidade de objetivos de um empreendimento pode superar as dificuldades de inserção de impacto social em empreendimentos de objetivo único, uma vez que maximização de valor socioambiental comumente conflita com maximização de lucros (DEES, 2001; AUSTIN; STEVENSON; WEISKILLERN, 2006).

O estudo dos modelos de negócios passa pela compreensão da forma como as organizações criam, entregam e capturam valor. Para isso, é necessário entender a inter-relação dos diversos elementos, ou componentes, que compõem um modelo de negócios (MORRIS et al., 2006). No entanto, não há consenso na literatura sobre quais são esses componentes e como eles são inter-relacionados (LAMBERT; DAVIDSON, 2013). A ausência de consenso motivou Pedroso (2016) a fazer uma revisão sistemática na literatura, abrangendo cinquenta trabalhos entre 1996 a 2015, para identificação dos principais componentes abordados pelos autores e sugestão de uma arquitetura, ou representação gráfica, unificadora de conceitos.

O autor classificou os componentes identificados no que definiu como sete dimensões: (1) estratégia; (2) proposta de valor; (3) modelo de operações; (4) modelo de relacionamento com clientes; (5) modelo de inovação e conhecimento; (6) modelo econômico; (7) modelo de gestão. As dimensões mais comumente identificadas nos trabalhos pesquisados foram:

1. Modelo de operações ( $100 \%$ dos trabalhos);

2. Modelo econômico ( $80 \%$ dos trabalhos);

3. Proposta de valor ( $76 \%$ dos trabalhos);

4. Modelo de relacionamento com clientes (62\% dos trabalhos).

As quatro dimensões de maior prevalência do estudo de Pedroso (2016) são os componentes da arquitetura de modelo de negócios proposto por Osterwalder e Pigneur (2010) 
e amplamente adotada por praticantes da administração. Os autores, através de seu Business Model Canvas, apresentam as quatro dimensões identificadas por Pedroso (2016), subdivididas em nove elementos que detalham os temas definidores das dimensões e facilitam a prática (Figura 2): 
Figura 2 - Quatro dimensões estratégicas por Osterwalder e Pigneur (2010)

Modelo de operações

Modelo de relacionamento com clientes

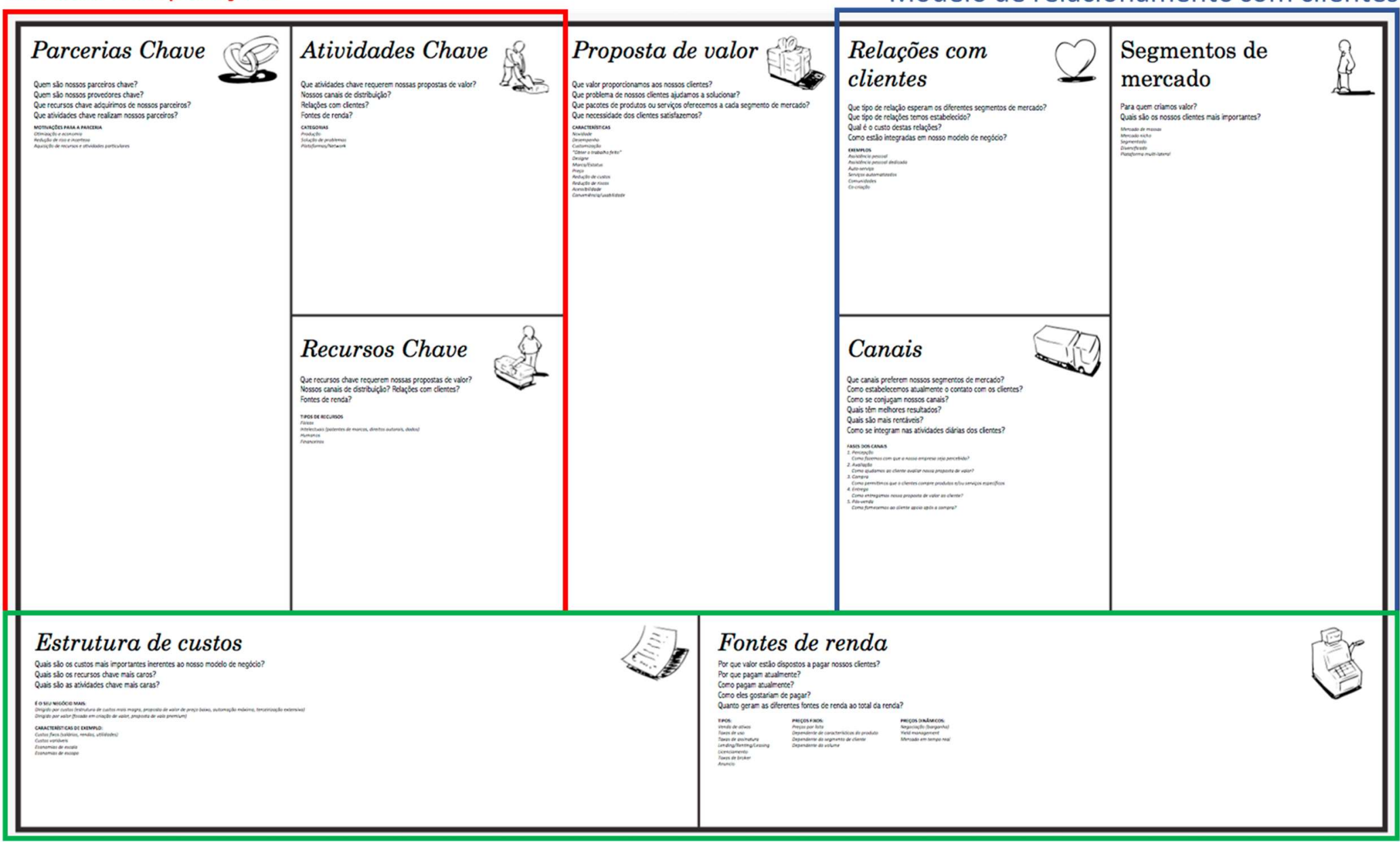

Modelo econômico

Fonte: Adaptado de Osterwalder e Pigneur (2010). 
A dimensão "estratégia" foi encontrada em $42 \%$ dos trabalhos pesquisados pelo autor. A baixa presença da dimensão se deve, possivelmente, à inter-relação entre modelos de negócios e estratégias, podendo os autores ter considerado relativa sobreposição entre os dois conceitos (PEDROSO, 2016).

As duas dimensões faltantes, modelo de gestão e modelo de inovação e conhecimento, foram encontradas pelo autor em $34 \%$ e $12 \%$ dos estudos pesquisados, respectivamente. $\mathrm{O}$ autor aponta a possível baixa citação do modelo de inovação e conhecimento devido à recente adoção da perspectiva dinâmica (mudanças no modelo de negócios que ocorrem ao longo do tempo) em modelos de negócios ou, ainda, à sua possível baixa relevância frente às demais dimensões, particularmente quando analisadas em empresas nascentes cujos modelos de negócios não foram consolidados. No entanto, o modelo de gestão tem grande relevância em modelos de negócios porque afeta tanto a forma como as atividades são realizadas nas demais dimensões, como a forma pela qual o negócio evolui ao longo do tempo (BOCK et al., 2012).

Pedroso (2016), em sua proposta de arquitetura de modelo de negócios a partir da literatura, optou pela compatibilização entre as perspectivas dinâmica e estática de um modelo de negócios, isto é, propôs uma arquitetura que tanto descrevesse um modelo de negócios em determinado momento, assumindo implicitamente sua estabilidade, como também representasse a forma pela qual a mudança dentro do modelo é estruturada e gerida (DEMIL; LECOCQ, 2010). O autor adotou seis das sete dimensões pesquisadas, eliminando a dimensão estratégia, e as definiu como:

1. Posicionamento estratégico - Definição do "binômio produto-mercado", união de estratégia e proposta de valor em um único elemento. São encontrados aqui os elementos produtos e mercado, posicionamento competitivo e proposta de valor aos clientes;

2. Modelo de operações - A forma com que a empresa trabalha os recursos de sua cadeia de valor, contempla modelo de suprimentos, modelo de produção e modelo de distribuição;

3. Modelo de relacionamento com os clientes - Como a empresa trabalha os recursos e processos orientados para o relacionamento com clientes, a segmentação de clientes, a marca e a comunicação;

4. Modelo econômico - Compreende os aspectos de criação e captura de valor (estrutura de custos, modelo de geração de receita e fórmula de lucro);

5. Modelo de inovação- Como a empresa estrutura recursos e processos de inovação e gestão do conhecimento, contemplando os subcomponentes inovação de produtos, 
processos e modelo de negócios;

6. Modelo de gestão - Determina como a administração da empresa é executada e inclui cultura e valores, sistema de gestão, governança e estrutura.

A arquitetura proposta pelo autor pode ser observada na Figura 3:

Figura 3 - Arquitetura do modelo de negócios

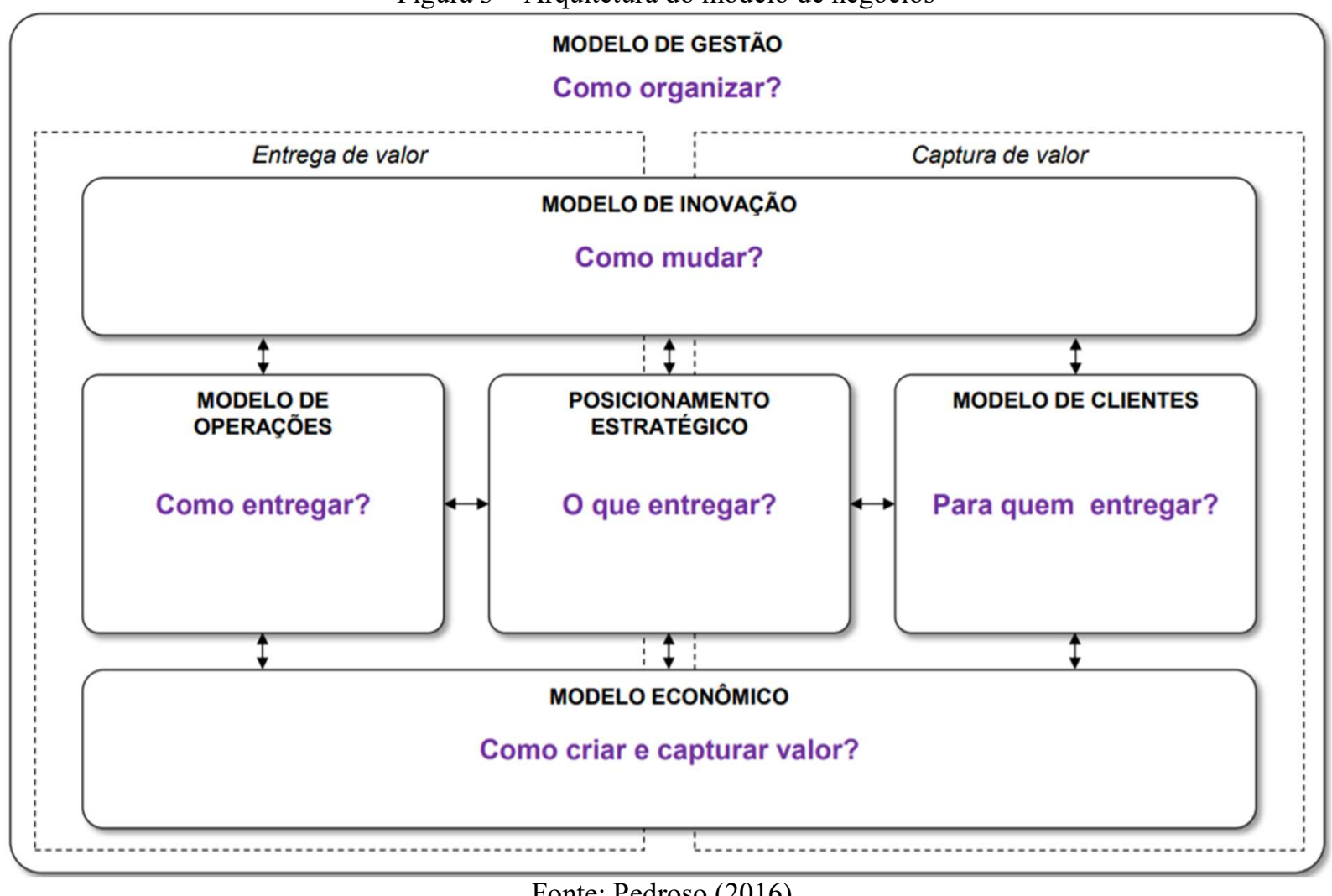

Fonte: Pedroso (2016).

Em sua arquitetura, Pedroso (2016) adota um único objetivo comum a todas as empresas: a geração de lucro e a criação e captura de valor estão limitadas à dimensão do modelo econômico. No entanto, o aumento do interesse em negócios com impacto social tem suscitado propostas de arquitetura de modelos de negócios, por pesquisadores e praticantes, a partir do já consagrado modelo de Osterwalder e Pigneur (2010), entre eles o Social Lean Canvas (2017), Stanford (2017), Tandemic (2017) e Burkett, Petrini, Scherer, \& Back (2016). Esses modelos têm em comum nas suas estruturas a presença da proposta de valor, definição de clientes, custos e modelo de receita, recursos, atividades e parceiros (Tabela 2).

O impacto social, tema central para as arquiteturas estudadas, foi abordado através de duas vertentes. Enquanto Stanford (2017) e Burkett (2016) introduziram o tema em cada elemento das quatro dimensões, as demais propostas consideraram o modelo de impacto social 
como uma quinta dimensão independente. Para as arquiteturas que adotaram o modelo de impacto social como uma dimensão independente, a definição do impacto foi elemento comum. A síntese dos elementos encontrados na análise pode ser observada na Tabela 2, abaixo.

Tabela 2 - Elementos presentes em arquiteturas de modelos de negócios sociais

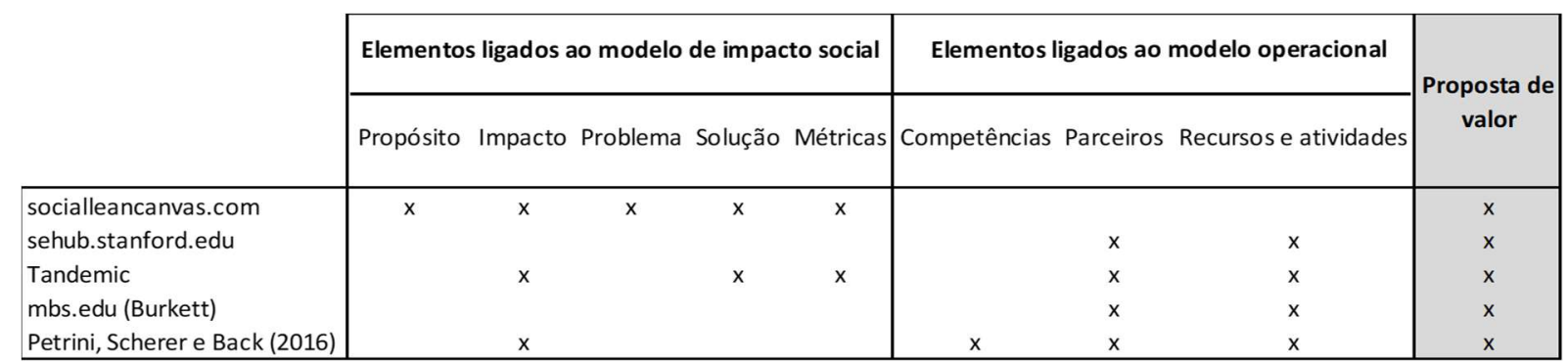

\begin{tabular}{|c|c|c|c|c|c|c|c|c|}
\hline & \multicolumn{5}{|c|}{ Elementos ligados ao modelo de clientes } & \multicolumn{3}{|c|}{ Elementos ligados a modelo econômico } \\
\hline & $\begin{array}{l}\text { Vendas e } \\
\text { marketing }\end{array}$ & Canais & Clientes & $\begin{array}{c}\text { Fatores } \\
\text { macroeconômicos }\end{array}$ & Concorrentes & Custo & Receita & Reinvestimento \\
\hline socialleancanvas.com & & $\mathrm{x}$ & $\mathrm{x}$ & & & $\mathrm{x}$ & $\mathrm{x}$ & \\
\hline sehub.stanford.edu & $\mathrm{x}$ & & $\mathrm{x}$ & $\mathrm{x}$ & $\mathrm{x}$ & $\mathrm{x}$ & $\mathrm{x}$ & \\
\hline Tandemic & & $x$ & $x$ & & & $x$ & $x$ & $x$ \\
\hline mbs.edu (Burkett) & & $x$ & $x$ & & & $\mathrm{x}$ & $\mathrm{x}$ & \\
\hline Petrini, Scherer e Back (2016) & & & $\mathrm{x}$ & & & $\mathrm{x}$ & $\mathrm{x}$ & $\mathrm{x}$ \\
\hline
\end{tabular}

Fonte: Elaborada pelo autor (2017).

O levantamento das cinco arquiteturas propostas evidenciou a indefinição sobre questões ainda em debate dentro da temática de negócios sociais, como a dificuldade e a debilidade na definição de métricas para mensuração de impacto (COMINI, 2016), que apareceu em apenas duas das cinco propostas, ou a finalidade do lucro obtido pela operação (reinvestimento, conforme defendido por Yunus (2007) ou remuneração dos investidores como mecanismo de atração de novos investimentos (CHU, 2007)). A finalidade do lucro também só foi abordada por dois dos cinco modelos encontrados.

Todos os modelos listados partem da proposta de Osterwalder e Pigneur (2010) e, de formas distintas, adicionam o valor social, ou geração de impacto, à sua arquitetura. Como o modelo de Osterwalder e Pigneur (2010) adota uma perspectiva estática de modelos de negócios, as dimensões da perspectiva dinâmica, como modelo de gestão e modelo de inovação (PEDROSO, 2016), não estão presentes em nenhum dos cinco modelos listados.

A perspectiva dinâmica do modelo de negócios permite o estudo das mudanças que ocorrem em uma organização (PEDROSO, 2016) e, sendo assim, tem alto potencial de aplicação a empresas em constantes mudanças ou ajustes, como as empresas nascentes. $\mathrm{O}$ entendimento das mudanças que ocorrem na organização é fator importante para a gestão tanto da mudança quanto da própria organização e, por esta razão, é pilar conceitual da metodologia 
de desenvolvimento ágil da startup enxuta (RIES, 2011), assim como da pesquisa-ação.

\subsection{A Startup Enxuta e a Pesquisa-Ação}

Em 2011 Eric Ries publicou o livro de título The Lean Startup (A Startup Enxuta), um compêndio de práticas para desenvolvimento rápido de softwares baseado na teoria de que, para o desenvolvimento de um produto ou negócio, é mais produtivo e econômico realizar múltiplos testes de conceito com ajustes incrementais do que buscar um desenvolvimento único e final para uma ideia preconcebida. Segundo o autor, é mais barato incorrer em inúmeros pequenos erros e consertá-los rapidamente do que errar em uma grande entrega final, após longo ciclo de desenvolvimento.

À parte das práticas e instrumentos apresentados pelo autor para o desenvolvimento de softwares, a publicação apresenta uma proposta ampla de método de se buscar uma solução, seja ela produto ou serviço, pautado em ciclos rápidos de desenvolvimento que passam pelas etapas de planejar, executar, medir e aprender (figura 4).

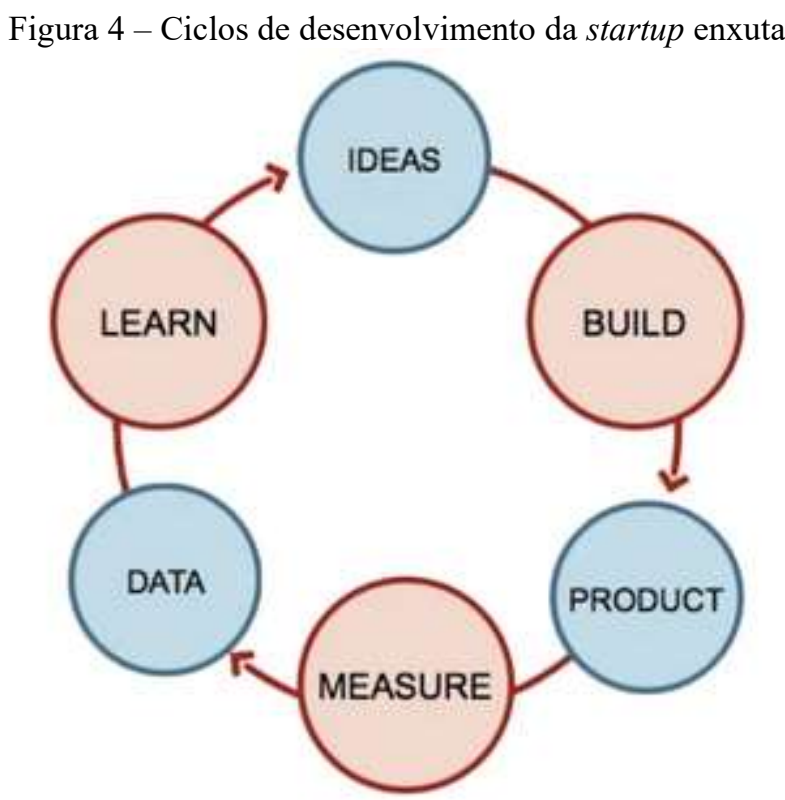

Fonte: Adaptado de Ries (2011).

A prática de planejar, executar, medir e aprender proposta por Ries não é, por si só, uma inovação em método. De fato, precedem várias outras propostas, como o PDCA (plan, do check and act) de Deming (1986), o conceito de controle total da qualidade de Ishikawa (1985) e, ainda, a própria origem do método científico no século XVII a partir do trabalho filosofal de 
Francis Bacon. A maior contribuição de Ries está relacionada à velocidade proposta para se percorrer e não o ciclo em si. Se as práticas precedentes, aplicadas às descobertas nas ciências puras ou evolução em processos fabris, propõem uma etapa de investigação e/ou planejamento profunda e detalhada como forma de obtenção de melhores resultados (descobertas científicas ou melhorias de processos), a prática proposta por Ries propõe a maior velocidade do ciclo e defende que, no cenário de desenvolvimento de softwares, pequenos erros expostos a grupos controlados e corrigidos de forma rápida, geram baixa externalidade e rápido aprendizado. Ao final, defende o autor, o processo de errar e corrigir rápido no desenvolvimento de softwares é mais produtivo e econômico que longos planejamentos e desenvolvimentos de produtos. $\mathrm{O}$ autor ainda defende a adoção da prática para cenários amplos de desenvolvimento de novos negócios, serviços e produtos.

Apesar da proposta de Eric Ries remontar à própria origem do método científico, o rigor científico não é uma premissa à sua execução no ambiente de empreendedorismo. $\mathrm{O}$ rigor científico, quando aplicado ao ciclo de investigação, executar, medir e aprender, caracteriza uma pesquisa-ação. Segundo Coughlan \& Coughlan (2002) uma pesquisa-ação se caracteriza por oito passos: contexto e propósitos, coleta de dados, retorno de dados, análise de dados, planejamento, implementação, avaliação e monitoramento. Pinto (1989) sintetiza o processo em três atividades: investigação, proposição e, por último, o de ação. Como sugestão do método em pesquisas de mestrados profissionais, Costa Filho \& Pedroso (2018) propõem uma simplificação do modelo e mesclam os três passos propostos por Ridling, Fowell, \& Levy (1995) de (i) planejar, (ii) agir e observar e (iii) refletir com o passo de contexto e propósitos de Coughlan \& Coughlan (2002), presente uma única vez antes do início dos ciclos com o propósito de fornecer uma visão sobre o cenário em que a pesquisa-ação ocorre (figura 5).

Figura 5 - Estrutura do método de pesquisa-ação

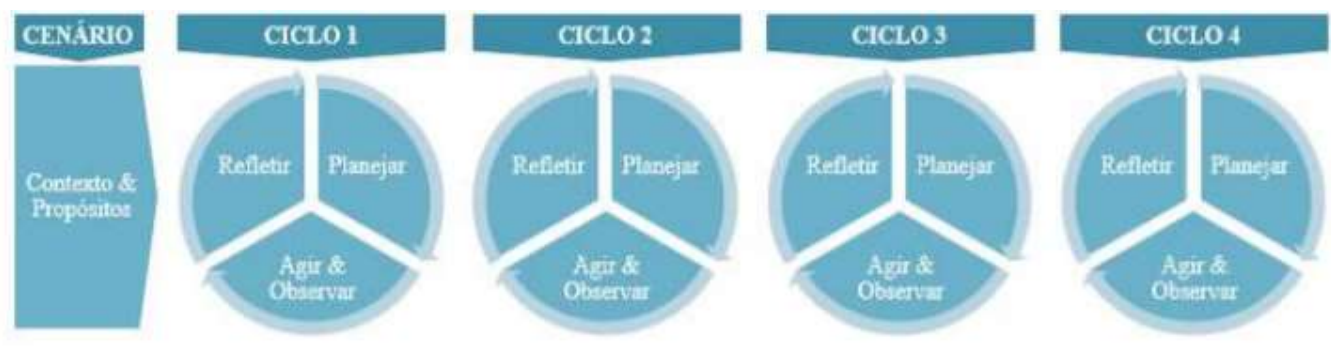

Fonte: Costa Filho \& Pedroso (2018)

O objetivo de uma pesquisa-ação, segundo Thiollent (2008), é duplo, um técnico e outro 
científico. O objetivo técnico se assemelha ao objetivo da startup enxuta, que é atuar na resolução de um problema por meio da ação do pesquisador. O objetivo científico é o que a diferencia ao trabalho meramente empírico, pois o condiciona à coleta e à análise de informações, de forma documental, para geração de conhecimento aplicado a diferentes contextos.

Uma pesquisa-ação, ao adotar o conceito de uma startup enxuta ao longo de sua execução, não se descaracteriza quanto ao seu rigor científico e método de coleta e análise de dados. No entanto, aceita que o passo de "planejar" seja acelerado, e muito provavelmente simplificado, com o objetivo de encurtar o tempo total dos ciclos e, assim, maximizar o número de ciclos percorridos dentro de um mesmo espaço de tempo. Há, portanto, uma elevação da valorização do aprendizado pela execução frente ao aprendizado pela investigação.

Como previamente apontado, este trabalho tem por objetivo propor e testar um modelo de negócio inclusivo viável no mercado de recrutamento e seleção, através do método de pesquisa-ação. Para isso se apoia no conceito de negócios inclusivos (MÁRQUEZ; REFICCO; BERGER, 2010), de valor compartilhado (PORTER; KRAMER, 2011) utilizando a arquitetura de modelo de negócios de Pedroso (2016) como ferramenta de planejamento e análise do negócio em diferentes estágios. A arquitetura de Pedroso (2016) foi adotada devido à sua inclusão da perspectiva dinâmica nos modelos de negócios. Acredita-se que seja a ferramenta mais adequada para análise de um negócio em desenvolvimento por ciclos rápidos (RIES, 2011). O valor social do empreendimento não foi tratado como uma dimensão apartada, mas sim inserido como elemento dentro das dimensões já definidas por Pedroso (2016). 


\section{MÉTODO DE PESQUISA}

Esta pesquisa tem como método a pesquisa-ação, seguindo a prática proposta por Costa Filho \& Pedroso (2018) para pesquisas em mestrados profissionais e apresenta quatro características comuns à pesquisa-ação (COUGHLAN \& COUGHLAN, 2002):

i. Utiliza abordagem científica para solução de problema experimentado na prática pelo pesquisador;

ii. Pesquisa e execução são concomitantes, não é pesquisa sobre execução passada, o que caracterizaria o método de estudo de caso;

iii. Os atores do objeto de estudo participam da construção da solução, como proposto por Thiollent (2008). Trata-se, portanto, de uma solução construída a partir de cooperação, e não a partir do conhecimento individual do pesquisador;

iv. É uma sequência de eventos em um ciclo de iteração de coleta e análise de dados e resolução de problemas.

O estudo parte de uma solução pré-definida em função da necessidade de melhorar a entrega do serviço, no caso conseguir alcançar os candidatos, de uma forma mais eficiente e ao mesmo tempo gerar valor social. A escolha de mães com filhos pequenos parte de duas premissas: dificuldade de acesso ao mercado de trabalho formal e consequente presença constante na comunidade onde moram.

Apesar da solução já estar pré-estabelecida, o foco da pesquisa, e seu objetivo, reside na descoberta do como entregar o serviço e não de qual serviço deverá ser entregue. O serviço pré-definido nesta pesquisa engloba tanto o valor que de fato é recebido pelo cliente (o recrutamento e seleção de profissionais para uma vaga em aberto) quanto o meio pelo qual é entregue (através de rede de mães em comunidades). No entanto, a participação dos atores na solução não é negligenciada e se faz presente na construção do aprendizado de como entregar tal serviço.

O Programa de Mestrado Profissional tem como pilar conceitual, assim como o método de pesquisa-ação, a busca de uma solução para um problema experimentado pelo pesquisador. O a metodologia proposta pelo Programa parte um problema real vivido pelo pesquisador para, em sequência, se pesquisar uma solução. O problema vivido pelo pesquisador é aqui relatado na Introdução e culmina na questão de pesquisa deste estudo. Nesta pesquisa, os subcapítulos 
Relato da Experiência, Histórico ADS, Situação-problema, Questão de Pesquisa e Objetivos Geral e Específicos compõem o que foi definido por Costa Filho \& Pedroso (2018) como “Contexto e Propósitos" da pesquisa-ação (figura 5), e precedem os ciclos de aprendizado que são a própria definição da pesquisa-ação.

\subsection{Os Ciclos de Aprendizado}

A pesquisa percorreu doze ciclos de aprendizado ao longo vinte e três meses de estudo (junho de 2016 a abril de 2018). A prática de pesquisa através de ciclos impõe ao pesquisador a tarefa de delimitação de um ciclo, podendo ser definido por um achado ou por um prazo de tempo. Neste estudo ambos foram adotados. O primeiro ciclo teve seu limite de duração definido pelo achado e perdurou por sete meses. O segundo ciclo, de seis meses, teve também longa duração devido ao detalhado processo de planejamento do novo empreendimento. Do terceiro ao décimo segundo ciclo o conceito de startup enxuta foi incorporado na pesquisa e o processo de descoberta de como entregar o serviço de recrutamento e seleção por rede ganhou maior dinamismo. Ao longo destes ciclos rápidos a pesquisa testou várias práticas e processos na busca pelo modelo operacional funcional e, para cada prática ser aprovada ou refutada, foi necessário estabelecer um prazo para que se obtivesse resultados positivos (um mês). Se tal delimitação temporal não fosse adotada, corria-se o risco de a pesquisa recair sobre a falha de buscar a viabilidade de uma prática a despeito do tempo e recurso para tal. Ao longo destes ciclos, todas as práticas e processos refutados o foram pela condição de não terem se provados viáveis ao longo de um mês de teste (ação), não podendo concluir que tais práticas e processos jamais se tornariam funcionais caso lhes fossem dado maior prazo de execução.

O objetivo do primeiro ciclo foi testar a capacidade de uma mãe em comunidade de recrutar e selecionar. O prazo para isso não era relevante e, sim, o achado. Mães em comunidades serem capazes de recrutar e selecionar é premissa para o objetivo da pesquisa e, portanto, esta descoberta superava em relevância o tempo que despendido para tal. O primeiro passo do ciclo foi analisar um caso de sucesso de negócio inclusivo feito para mulheres em comunidades e entender seu histórico de fracassos e sucessos, e foi definido como o passo "Planejar". Este precedeu a execução de um teste piloto de recrutamento e seleção através de uma mãe em uma comunidade. O teste piloto caracterizou o "Agir e Observar" do primeiro ciclo e os aprendizados obtidos definiram o "Refletir" do ciclo (figura 6). 
Figura 6 - Primeiro ciclo

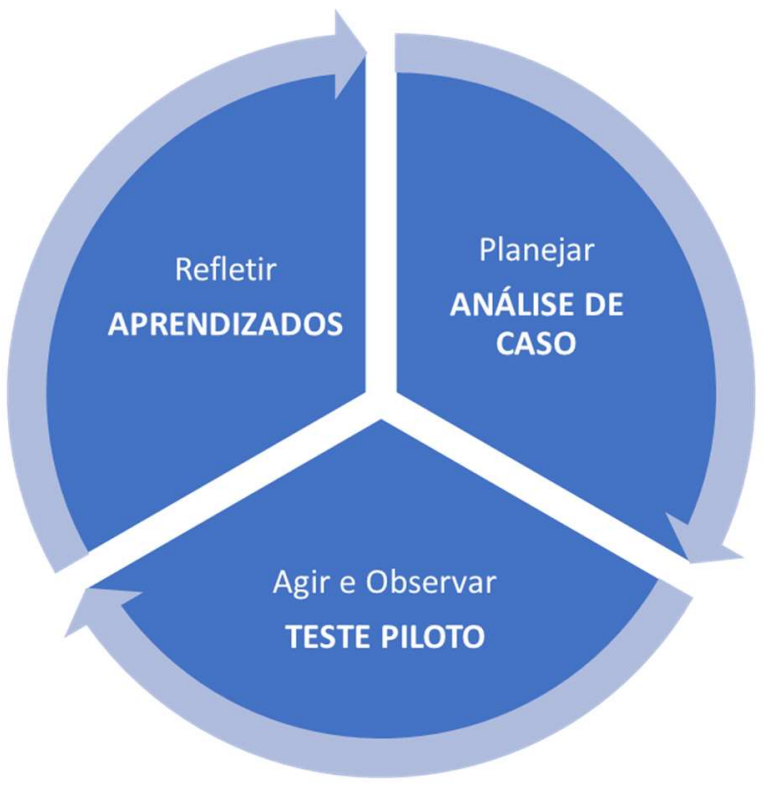

Fonte: Elaborado pelo autor (2018)

O segundo ciclo foi marcado pelo processo de planejamento do novo empreendimento (Planejar) que durou cinco meses e, ainda, o primeiro mês de operação do negócio (Agir e Observar), como pode ser visto na figura 7.

Figura 7 - Segundo ciclo

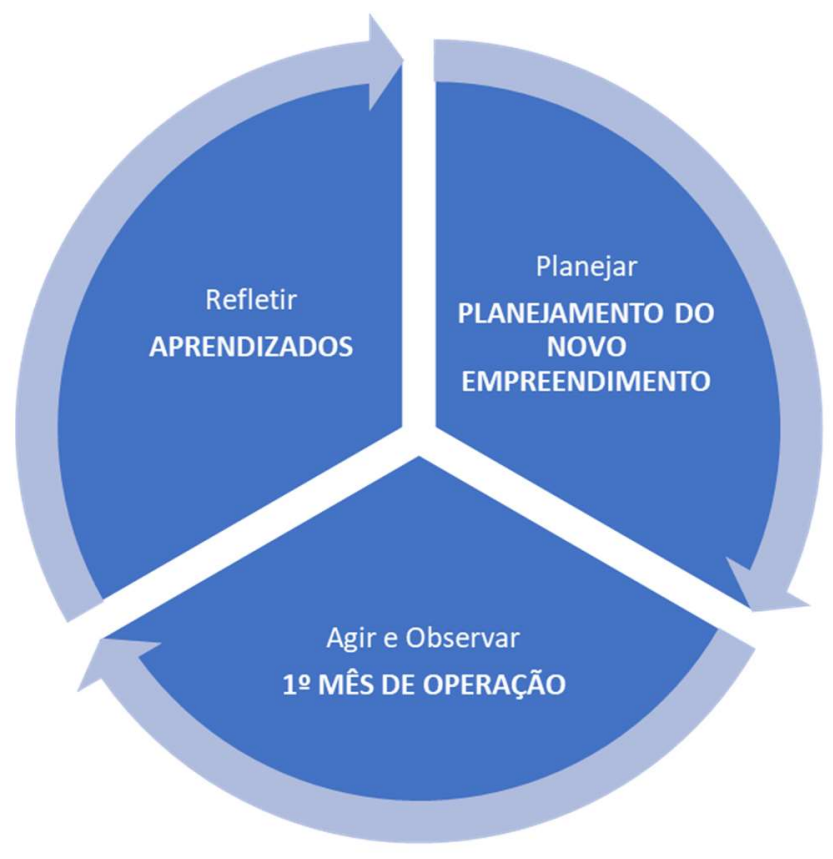

Fonte: Elaborado pelo autor (2018) 
Do terceiro ao décimo segundo ciclo da pesquisa houve homogeneidade no tempo de duração: um mês. O passo inicial de cada ciclo consistiu em planejar mudanças em processos e práticas improdutivos do negócio, que pudessem ser imediatamente aplicadas e ter seus resultados mensurados dentro do espaço de tempo pré-estabelecida, sendo a aplicação e mensuração a definição do segundo passo. A aprovação ou reprovação de cada nova prática ou processo fez parte do passo "Refletir" de cada ciclo e serviu como informação de entrada para o início do ciclo seguinte (figura 8). Esse exercício de planejamento, execução e avaliação de cada ciclo garantiram rigor analítico e fundamentos para as decisões, elementos fundamentais à caracterização da pesquisa-ação como trabalho científico, uma vez que objetivos e procedimentos específicos (hipóteses) em cada ciclo foram testados e validados ou não. Os mapas visuais apresentam uma síntese deste processo, em cada ciclo.

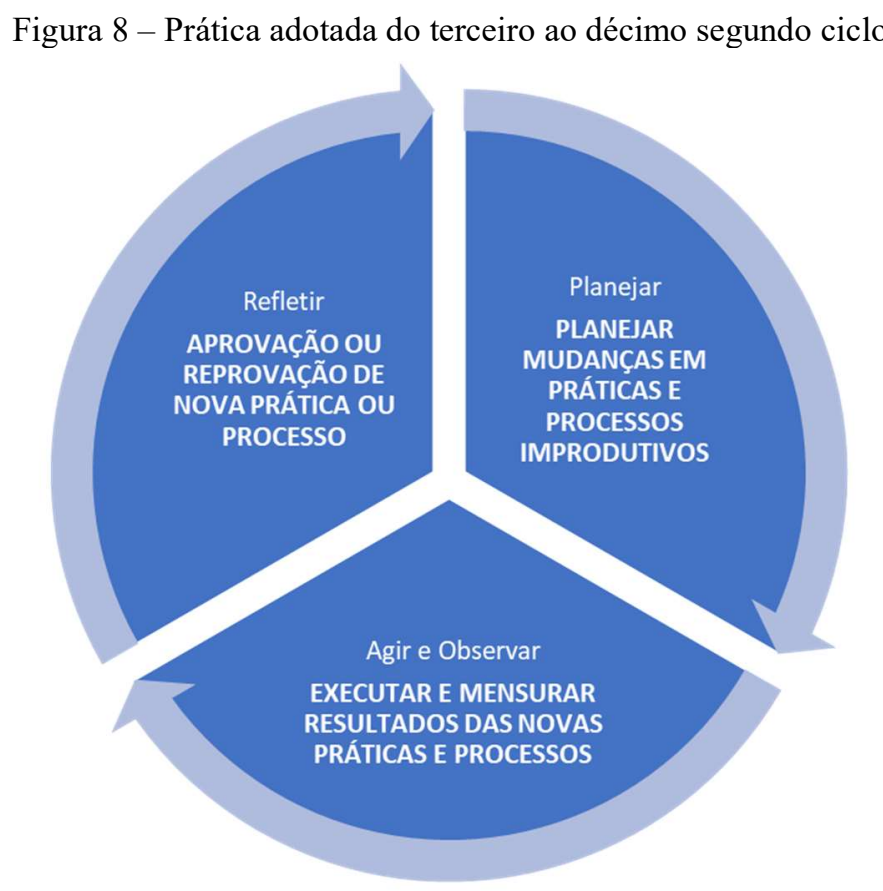

Fonte: Elaborado pelo autor (2018)

\subsection{A Coleta de Dados}

Ao longo da pesquisa dados de natureza distintas foram coletados conforme a necessidade de informação e aprendizado de cada ciclo. O primeiro passo do primeiro ciclo, a análise de caso Danone, utilizou de hard data, como relatórios e informações financeiras da instituição e soft data, como entrevistas formais semiestruturadas presenciais (Apêndices A e B), gravadas, com a gestora do programa na Danone e o gestor de sua principal parceira no 
programa, a ONG Visão Mundial.

Para a análise de caso buscou-se um empreendimento que pudesse servir de espelho para o modelo idealizado para a ADS. O modelo idealizado para a ADS tinha quatro características definidoras:

i. Um negócio de pequeno porte;

ii. Mães de crianças fora da idade escolar e residentes em comunidades como grupo social a ser impactado;

iii. Grupo social impactado fazendo parte da cadeia produtiva do empreendimento, com atuação individualizada dentro da comunidade;

iv. Operação capilarizada.

A referência encontrada no mercado com maior proximidade ao modelo foi o Projeto Kiteiras da Danone. Apesar da nítida diferença de porte das empresas (i), os demais critérios se assemelhavam muito, uma vez que o Kiteiras trabalhava com centenas de mulheres dentro de comunidades vendendo produtos da Danone. Tratava-se, portanto, de uma operação capilarizada, com atuação individualizada em um trabalho autônomo de mulheres em suas comunidades, três das quatro características traçadas para a ADS.

O segundo passo do primeiro ciclo, o teste piloto, contou com soft data, como observações diretas do pesquisador, entrevista informal documentada em anotações com a mãe participante do estudo e hard data, como o resultado de candidatos contratados durante o teste.

Os onze ciclos seguintes se caracterizaram pela construção de processos e práticas internas e interações com as mães nas comunidades em uma construção conjunta de modelo de operação funcional para o novo empreendimento. Ao longo destes ciclos foram coletados e registrados no estudo tanto soft datas, tais como a evolução do modelo operacional, decisões tomadas, sentimentos e motivadores envolvidos e observações diretas do pesquisador, como hard datas, como os resultados operacionais do empreendimento.

\subsection{A Demonstração de Dados}

Por se tratar de uma pesquisa processual, fez-se necessário a adoção de uma narrativa como forma de facilitação da apresentação, análise e discussão dos dados coletados (MELLO, TURRIONI, XAVIER \& CAMPOS, 2012). O estudo de eventos e ações retratados ao longo 
do tempo, em um contexto também explícito, teve por objetivo explicar como e porque tais eventos evoluíram da forma que o fizeram, permitindo o aprendizado e entendimento das situações e, por consequente, evoluir na prática e conhecimento (KOLB, 1984). A narrativa, ou narrative strategy, foi aplicada majoritariamente na demonstração de soft datas da pesquisa, com intuito de aumentar a riqueza em detalhes do relato, abordando, por exemplo, sentimentos envolvidos pelos atores da pesquisa e explicando, de forma cronológica, eventos considerados representativos.

A narrative strategy permitiu o registro detalhado, por parte do pesquisador, sobre os eventos ocorridos ao longo da pesquisa-ação. A riqueza destes detalhes permite fazer posteriormente análises mais precisas (MELLO, TURRIONI, XAVIER \& CAMPOS, 2012), mas falha na simplificação da apresentação de resultados de hard data coletados. Como a pesquisa assumiu a mensuração de resultados práticos e quantificáveis desde o primeiro ciclo, foi adotado o visual mapping strategy (COSTA FILHO \& PEDROSO, 2018) como forma de demonstração de resultados de cada ciclo. Como mapa visual foram utilizados dois recursos para retratar os resultados de cada ciclo:

i. Arquitetura de modelo de negócios de Pedroso (2016): utilizado para retratar a evolução do modelo de negócio do novo empreendimento.

ii. Ciclo do método de pesquisa-ação de Costa Filho \& Pedroso (2018): utilizado para sintetizar a narrativa de cada ciclo e explicitar resultados obtidos. 


\section{CICLOS DE APRENDIZADO}

\subsection{Primeiro Ciclo}

O primeiro ciclo da pesquisa-ação teve como passo "Planejar" a análise de caso Danone, que forneceu insumos para planejamento da execução do teste piloto, definido com o passo "Agir e Observar".

\subsubsection{Narrativa}

\subsubsection{Análise de Caso Danone}

Para entender o Projeto Kiteiras é preciso entender quem o financia. A Danone possui um fundo para investimentos em projetos regionais de impacto social ou ambiental chamado Danone Écosystème. Esse fundo foi criado em 2010 com o valor de cem milhões de euros e foi através desse fundo que o Projeto Kiteiras foi concebido. A missão do fundo é traduzida assim: "Financiar e cooperar na criação de competências socioeconômicas de populações locais que trabalham com a Danone, por meio de parcerias inclusivas que reforcem esse ecossistema e contribuam para um bem maior (FUNDO ÉCOSYSTÈME, 2016)”.

Ecossistema, nesse caso, é uma comunidade econômica sustentada por uma base de organizações que interagem e giram em torno de bens e serviços (MOORE, 1996). O conceito de ecossistema organizacional extrapola a ideia tradicional de cadeia de valor, pois inclui organizações tanto empresariais quanto setoriais, além dos tradicionais fornecedores e distribuidores. A metáfora de ecossistemas organizacionais com o termo dos estudos biológicos é justificada pela complementaridade e interdependência existente entre membros de uma comunidade de negócios, assim como um ecossistema biológico (MÁRQUEZ; REFICCO; BERGER, 2010).

O Danone Écosystème possui recursos próprios desvinculados das operações do grupo, o que permite fomentar projetos de longo prazo sem comprometer resultados operacionais de curto prazo. Essa desvinculação concede maior liberdade para a execução dos projetos, uma vez que estes não estão atrelados ao resultado da Danone, numa posição de investidor paciente. Uma particularidade dos projetos financiados pelo fundo é que todos devem ser cooperados com uma ONG. De fato, os recursos direcionados para os projetos são repassados diretamente às respectivas ONGs parceiras e não à operação local da Danone. 


\subsection{Conceito}

O Projeto Kiteiras tem como propósito desenvolver a capacidade empreendedora de mulheres de baixa renda da região Nordeste do Brasil. Essa região possui o menor IDH do país (2005), a segunda maior população do país e uma população feminina equivalente a $54 \%$ do total da região.

Para alcançar o objetivo de impactar, do ponto de vista socioeconômico, as mulheres da base da pirâmide social da região Nordeste, o projeto segmentou seu público de impacto a mães solteiras e donas de casa de meia idade, onde, segundo a gestora do programa, $35 \%$ das famílias são lideradas por mães solteiras.

A atividade proposta pelo projeto é a venda direta de produtos Danone pelas "kiteiras", com a meta de "empoderar" essas mulheres por meio de:
i. $\quad$ oportunidade de trabalho flexível;
ii. geração de renda;
iii. capacitação para a vida e o empreendedorismo;
iv. fortalecimento da autoestima.

Para a Danone, o projeto gera valor econômico ao aumentar a penetração de seus produtos lácteos frescos na base da pirâmide por meio do aumento da capilaridade de distribuição na região.

\subsection{Execução}

O projeto começou em 2011, um ano após a criação do fundo Écosystème, e três premissas foram estabelecidas pelo fundo: deveria gerar renda para a população, fomentar o empreendedorismo e "empoderar" as mulheres. Uma vez definidas as premissas, estas foram atreladas a uma necessidade da Danone Brasil: aumentar a penetração dos produtos da empresa em Salvador/BA, capital onde os produtos Danone detinham a menor fatia de mercado, motivo pelo qual o Projeto Kiteiras foi elaborado tendo a cidade soteropolitana como mercado teste.

Uma vez que o Fundo Écosystème condiciona o financiamento dos projetos a parcerias com ONGs locais, a Aliança Empreendedora, ONG situada em Curitiba/PR e especializada em fomentar o empreendedorismo nas classes sociais mais baixas, foi escolhida como parceira e gestora financeira do projeto. A primeira experiência adotada pela empresa foi a de venda de 
rua, ou venda móvel, em que a pessoa utiliza um carrinho com isolamento térmico e comercializa os produtos pelas ruas. O modelo é amplamente difundido no mercado de sorvetes no palito e, no segmento lácteo, popularizado pela empresa Yakult. No primeiro momento a Aliança Empreendedora ficou responsável pelo recrutamento das revendedoras em Salvador e o fez mediante recrutamento porta-a-porta.

Ao final de 2012, constatado o insucesso do projeto devido à incapacidade de recrutar pessoas para a função de kiteira, foi decidida a contratação de uma empresa de recrutamento soteropolitana para realizar a atividade.

Em 2013, ainda diante de um cenário de insucesso do modelo, ficou entendido que o modelo de comercialização estava equivocado. O modelo de venda demandava esforço físico e ausência do lar, condições que inviabilizavam a atração de mães solteiras pelo projeto. Constatado o equívoco, o modelo foi substituído pela venda direta por catálogo. Neste segundo modelo as vendas são realizadas através de kits (agrupamento de produtos), não há venda de produtos avulsos, os produtos são comercializados a preços regulares de mercado e o catálogo é alterado a cada três meses. A fonte de inspiração para o modelo veio da indústria de cosméticos, que já atua há décadas com venda por catálogo. Para viabilizar a cadeia logística, novos distribuidores dedicados ao projeto foram contratados. Esses distribuidores entregam pequenos volumes diretamente na casa das kiteiras.

No entanto, o resultado continuou insatisfatório e ficou evidente para a Danone que a forma de captação pautada em panfletos, carro de som e abordagem em vias públicas estava equivocada. Também não era eficaz o processo de seleção que contemplava dinâmicas e entrevistas para uma pessoa que, na prática, deveria atuar de forma autônoma e independente. $\mathrm{O}$ insucesso no recrutamento impactou a cadeia. $\mathrm{O}$ orçamento do fundo de investimento assegurava a solidez da ONG parceira dentro do projeto, mas o mesmo não pode ser dito sobre os distribuidores. Em um prazo de quatro anos, a baixa escala na distribuição acarretou a falência dos dois primeiros distribuidores que ingressaram no projeto.

Conceitualmente o projeto era promissor, contudo o cenário se mostrava cada vez mais complicado e a viabilização financeira parecia distante. Com o objetivo de reverter essa situação, algumas melhorias foram implementadas com destaque para a criação da figura da "madrinha". A "madrinha" é uma pessoa articulada, com grande aceitação na comunidade e capaz de construir redes de relacionamentos. A função primordial da "madrinha" é articular e gerir o grupo de kiteiras. Para isso, a "madrinha" responde pelas vendas do grupo, bem como pelo desenvolvimento profissional das kiteiras, incluindo a execução de treinamentos. Além 
disso, a "madrinha" é responsável por consolidar os pedidos de todas as componentes do grupo e informar o distribuidor.

Em 2014, ao tomarem conhecimento do Programa Escala do Banco Interamericano de Desenvolvimento (BID), a Danone submeteu o Projeto Kiteiras à análise. O Programa Escala, assim como o Écosystème, condiciona o investimento ao fato de o projeto estabelecer parceria com ONG local, que investe uma parceria com os projetos. Para o caso, o Programa Escala condicionou o aporte financeiro à entrada da Visão Mundial no projeto, em substituição à Aliança Empreendedora. A Visão Mundial é uma ONG com atuação global focada em bemestar infantil e possui um programa chamado PDA (Programa de Desenvolvimento de Área) que possui uma metodologia de mapeamento das lideranças locais e estabelecimento de relações de confiança nas comunidades. Em julho de 2015, a Visão Mundial começou as atividades de captação de kiteiras e foi determinante para o sucesso do projeto. A estratégia da ONG era divulgar a oportunidade nas redes que já haviam estruturado e em eventos das comunidades, sempre utilizando as lideranças locais para informar e dar respaldo ao projeto. À época, a Danone possuía um histórico recorde de quatrocentas kiteiras, mas naquele mês contava com apenas 350 pessoas no programa. Em setembro do mesmo ano o número de kiteiras já havia alcançado novecentas pessoas. Em dois meses a Visão Mundial conseguiu gerar uma base de kiteiras maior do que o projeto havia conseguido desde a sua origem. Ao contrário da Aliança Empreendedora, que utilizou metodologia tradicional de recrutamento e seleção aplicada a kiteiras, a Visão Mundial usou a sua rede de lideranças comunitárias que, atuando de forma capilarizada e respaldando o programa, obteve sucesso na captação de mulheres para a atividade.

O sucesso do projeto na cidade de Salvador motivou a sua replicação. O programa chegou à cidade de São Paulo em fevereiro de 2016 e em junho do mesmo ano já contava com 350 kiteiras na cidade.

\subsection{Resultados}

Em setembro de 2015, após totalizar novecentas kiteiras, o projeto atingiu o lucro operacional e a sustentabilidade financeira. O resultado deixado pela operação do Projeto Kiteiras em 2015 foi de 10\%, contra 15\% da operação de iogurtes da Danone Brasil. Apesar da menor margem operacional, o resultado é entendido como lucro marginal e, portanto, agrega valor financeiro à empresa. Isso é inferido devido à baixa penetração e ao market share que a companhia possuía no mercado soteropolitano e que vem sendo revertido à medida que o 
número de kiteiras se expande. O mercado que a Danone alcança hoje em Salvador não seria possível pelo modelo tradicional de distribuição e comercialização. Um dado curioso sobre o mercado de iogurte no Brasil é que o consumo per capita anual é de 7,5 $\mathrm{kg}$, ao passo que no Estado da Bahia é de apenas $4 \mathrm{~kg}$. No entanto, o consumo mensurado pela Danone referente aos consumidores que são atendidos pelas kiteiras é de $8 \mathrm{~kg} / \mathrm{ano}$, superior até mesmo à média brasileira.

Quanto à contribuição social, entende a Danone que o principal objetivo e indicador é a renda gerada para as kiteiras. Essas revendedoras têm margem de 30\% sobre as vendas que realizam e, em média, recebem $\mathrm{R} \$ 380,00$ por mês. Apesar de a renda média ser baixa, para uma grande parcela de kiteiras esse valor serve para complementar a renda familiar. O projeto observou ainda que as kiteiras que dedicam mais de cinco horas diárias à atividade recebem, em média, R \$1.350,00. Fica evidente que a dedicação exclusiva à atividade pode gerar ganhos superiores a um salário-mínimo, à época $\mathrm{R} \$ 880,00$. Além da renda, a Danone entende que contribui socialmente com as kiteiras através dos treinamentos sobre empoderamento feminino, saúde e nutrição. O turnover, que já foi de $25 \%$, estava à época em $10 \%$ e é considerado saudável, uma vez que é identificado que a maioria das kiteiras que deixam o programa o fazem porque conseguiram melhor oportunidade de emprego.

Estruturar negócios inclusivos demanda mudanças na forma de fazer negócios (TEODÓSIO; COMINI, 2012) e, quando o negócio se sustenta através de uma rede de participantes, demanda também habilidade para construir uma rede de relacionamentos de confiança. O reconhecimento da Danone de que a empresa não possui tal competência e a adoção de um modelo de empreendimento que busca o acesso a tais competências mediante parcerias com ONGs, como proposto por Márquez (2010), como melhores práticas para grandes empresas, se mostrou profícua e determinante para o sucesso do negócio. Essa constatação suscitou a questão de que, apesar de a ADS ser um pequeno negócio, a distância social entre os gestores e o grupo social a ser impactado a coloca em condição similar à enfrentada pela Danone. Portanto, o melhor caminho para construir a própria rede de agentes de recrutamento deveria passar pela construção de parcerias com ONGs e lideranças locais.

\subsubsection{Teste Piloto}

Em novembro de 2016 o primeiro teste piloto foi realizado com o propósito de validar o conceito proposto. $\mathrm{O}$ que se propunha era que uma rede ampla de mães com crianças em idade 
pré-escolar, atuando como recrutadoras e selecionadoras em suas comunidades, seria mais eficaz que o modelo tradicional de recrutamento e seleção. Esse era o conceito de sustentação comercial e operacional do modelo, mas na fase piloto o ponto central era identificar o potencial impacto nas mães envolvidas no projeto.

Para realizar o teste foi escolhida a inauguração de loja de uma grande rede de restaurantes fast food. Àquela época, a ADS tinha como principal cliente uma rede de restaurantes. Os maiores volumes de vagas demandadas pelo cliente eram referentes à inauguração de restaurantes. Um novo restaurante demanda entre 15 e 35 atendentes de restaurantes (cargo inicial), além de supervisores e gerente de restaurante. O perfil do atendente de restaurante é um jovem que comumente reside em comunidades carentes, frequentemente sem experiência profissional, em busca do primeiro emprego enquanto cursa o ensino médio. A remuneração é abaixo do salário-mínimo (jovem aprendiz), registrado em carteira e em jornada 6 x 1 (trabalha seis dias e descansa um). Para os turnos da noite, há a necessidade de que o profissional seja maior de idade e a remuneração para o cargo é superior. Há poucas restrições para a posição: é necessário estar cursando ou ter finalizado o ensino médio, ser aprovado em um teste simples de português e matemática e em exame parasitológico (obrigação para profissionais que trabalham com manipulação de alimentos).

O restaurante a ser inaugurado e que fora escolhido para o piloto era em São Bernardo do Campo/SP e, portanto, precisávamos de uma mãe nas proximidades do restaurante para realizar o teste. Seguindo o aprendizado com a análise de caso do Projeto Kiteiras, condizente com os achados dos 33 casos estudados por Márquez et al. (2010), a ADS foi em busca de uma liderança local para indicar uma mãe que pudesse participar do piloto. Era o esboço de uma primeira aproximação com lideranças. Como liderança foi escolhido um líder religioso ligado a um profissional da ADS, que prontamente fez a conexão com uma mãe. A ideia foi proposta à mãe como um teste, como uma atividade pontual sem garantia de recorrência e com remuneração em caso de sucesso por candidato contratado, assim como seria no modelo de negócio imaginado.

Juliana era mãe de duas crianças e estava desempregada por ter sido dispensada durante a crise. O perfil era ligeiramente distinto do idealizado: ela não trabalhava por falta de oportunidade de emprego, e não por não ter com quem deixar seus filhos. À época em que tinha um emprego, seus filhos ficavam com os avós durante o dia e poderiam voltar a essa rotina se ela conseguisse recolocar-se. Diante do desemprego e da proposta vinda por intermediação de alguém de sua confiança, Juliana se sentiu segura em trabalhar com remuneração no sucesso e concordou com a proposta da ADS. 
A opção de Juliana pela ADS foi feita por conveniência. O prazo para recrutar os profissionais para a inauguração do restaurante era muito curto. Independentemente do piloto a ser executado, as contratações deveriam ser concluídas nesse período. Não havia um recurso dentro da ADS alocado exclusivamente para coordenar o projeto-piloto. Os dois profissionais responsáveis pelo teste também eram encarregados de fazer o processo de recrutamento e seleção convencional e assegurar a equipe para a inauguração. Esse cenário provocou em ambos um imediatismo que não thes permitiu fazer um processo meticuloso na seleção da mãe que participaria do piloto, e foi então escolhida a que primeiro se apresentou como candidata.

Juliana recebeu todas as instruções de que precisava quanto ao perfil desejado para a posição: precisava buscar jovens interessados em ocupar o cargo de atendente de restaurante. Como a ADS está localizada no Centro da cidade de São Paulo, toda a comunicação entre a empresa e Juliana foi feita por telefone e WhatsApp. Uma vez iniciado o teste, Juliana e equipe da ADS trabalhavam em paralelo, buscando os candidatos para as posições. O processo de seleção foi realizado em data única, em São Bernardo do Campo, onde todos os candidatos fizeram provas e entrevistas. Juliana ficou responsável por agendar com seus candidatos a presença no processo seletivo, como fora feito pela equipe da ADS.

A experiência acumulada da ADS indicava que era necessário agendar três candidatos para cada vaga aberta a fim de poder fechar todas as vagas em aberto. Apesar da confirmação de presença, um terço dos candidatos agendados não compareceu ao processo seletivo e metade dos que compareciam era eliminada no processo seletivo. Para o restaurante a ser inaugurada, (o)havia 25 vagas de atendentes de restaurantes, e ao final de duas semanas de trabalho a equipe da ADS enviou 67 candidatos para o processo seletivo, enquanto Juliana enviou outros onze candidatos. O processo seletivo foi bem-sucedido e a inauguração foi assegurada para a data planejada. Todos os 25 atendentes foram contratados e havia sete outros pré-aprovados aguardando desistência.

Juliana teve seis de seus onze candidatos aprovados e recebeu R $\$ 150,00$ por cada aprovado, totalizando R \$900,00. Em entrevista, após a experiência, relatou suas percepções sobre o que fora vivenciado:

- Esperava ter mais candidatos aprovados. Apesar de ter conquistado uma renda a qual não poderia esperar ter dois meses antes, havia a sensação de oportunidade perdida por ter tido tantos candidatos reprovados; 
- A atividade era menos produtiva que o imaginado, muitas pessoas recusavam uma proposta de trabalho e, principalmente, não honravam compromissos do processo seletivo;

- $\mathrm{R} \$$ 900,00 era bem-vindo, mas ela não se dedicaria exclusivamente à atividade por menos de R\$ $1.500,00$ por mês. Seu foco continuava sendo voltar ao mercado de trabalho, precisava de melhor remuneração e maior segurança de ganhos.

O teste piloto com a Juliana foi revelador em diversos aspectos. A primeira constatação, que trouxe bastante conforto, é que era possível fechar vagas através de recrutamento e seleção por agente externa à ADS. Isso era o cerne da ideia, e era válido.

A baixa produção da Juliana fez suspeitar, em uma primeira análise pouco cautelosa, que havia indícios de que o modelo era improdutivo e, eventualmente, não sustentável. Juliana encaminhou um volume de candidatos muito inferior ao da dupla interna da ADS. Enquanto a dupla teve uma média individual superior a 33 candidatos enviados, Juliana teve apenas um terço desse número: onze. No entanto, os dois funcionários da ADS tinham dedicação exclusiva ao tema, trabalhavam quarenta horas semanais na atividade, dispunham de ferramentas e, principalmente, tinham experiência em recrutar para a posição. Já Juliana nunca havia trabalhado nessa atividade e a desenvolveu apenas em três semanas, sem treinamento ou ferramenta específica para a atividade. Apesar de ter tido menor produtividade, Juliana teve maior qualidade em seu trabalho de recrutamento e seleção. Enquanto a equipe da ADS manteve um índice próximo aos usuais 30\% de aprovação dos candidatos enviados, Juliana teve um aproveitamento quase duas vezes superior, $55 \%$.

O teste apresentou indícios de que o modelo de recrutamento e seleção por rede poderia ser menos produtivo per capita, mas seria mais efetivo. A menor produtividade de uma mãe autônoma, quando comparada à de um profissional de recrutamento e seleção, indicava que a proporção de mães recrutadoras por vaga deveria ser maior que a experiência de mercado para funcionários recrutadores por vaga, mas, em contrapartida, havia potencial para que o serviço dessas mães fosse mais assertivo.

Outra constatação com a experiência foi a necessidade de haver alto volume de vagas a serem trabalhadas pelas mães e com demanda constante pelo serviço delas, uma vez que a previsibilidade de renda seria fator decisivo para o maior envolvimento com a atividade, como relatou Juliana. A ADS ainda era uma pequena empresa de recrutamento e seleção tentando sobreviver e se estabelecer em um mercado de crise e com recorde de desemprego. Não havia demanda suficiente para equilibrar a equação. Ao final da experiência com Juliana, em 
novembro, não havia expectativa real de vagas para a região de São Bernardo do Campo para os próximos dois ou três meses, talvez nem mesmo as dez vagas mensais almejadas por ela.

Ao unir todos os aprendizados da experiência, ficou entendido que:

- Uma mãe era capaz de recrutar e selecionar profissionais em sua comunidade para vagas operacionais;

- Uma mãe dificilmente conseguiria fechar mais de seis vagas (Juliana precisou trabalhar um único perfil para conseguir esse número);

- O perfil de uma mãe para trabalhar no modelo deveria ser alguém que encontrasse nele uma oportunidade e enxergasse um salário-mínimo como uma boa remuneração;

- A ADS jamais seria capaz de gerar demanda suficiente para criar sua própria rede de mães a fim de atender às suas vagas.

Esse piloto constatou que a proposta de incluir mulheres que vivem em comunidades carentes como recrutadoras era viável para ADS, mas exigia reformulações para ser interessante como fonte de trabalho para essas mulheres. O caminho para a solução era nítido: um modelo que aumentasse vertiginosamente o volume de vagas e ainda mantivesse o conceito-raiz de mães recrutando em comunidades. Para isso, era fundamental o volume de vagas, que uma única empresa como a ADS não daria conta de ofertar. Esse modelo, inegavelmente, não era a ADS. Os planos de tornar a ADS um negócio inclusivo atuando em rede mostrou-se inviável, mas nascia uma nova ideia: uma plataforma para anúncio de vagas por contratantes e distribuição das vagas para as agentes de recrutamento residentes mais próximo do local da vaga. Essa plataforma de captação e distribuição de vagas seria um novo negócio, inclusivo pela sua concepção, e demandaria planejamento e testes de viabilidade. 
Figura 9 - Mapa visual do primeiro ciclo

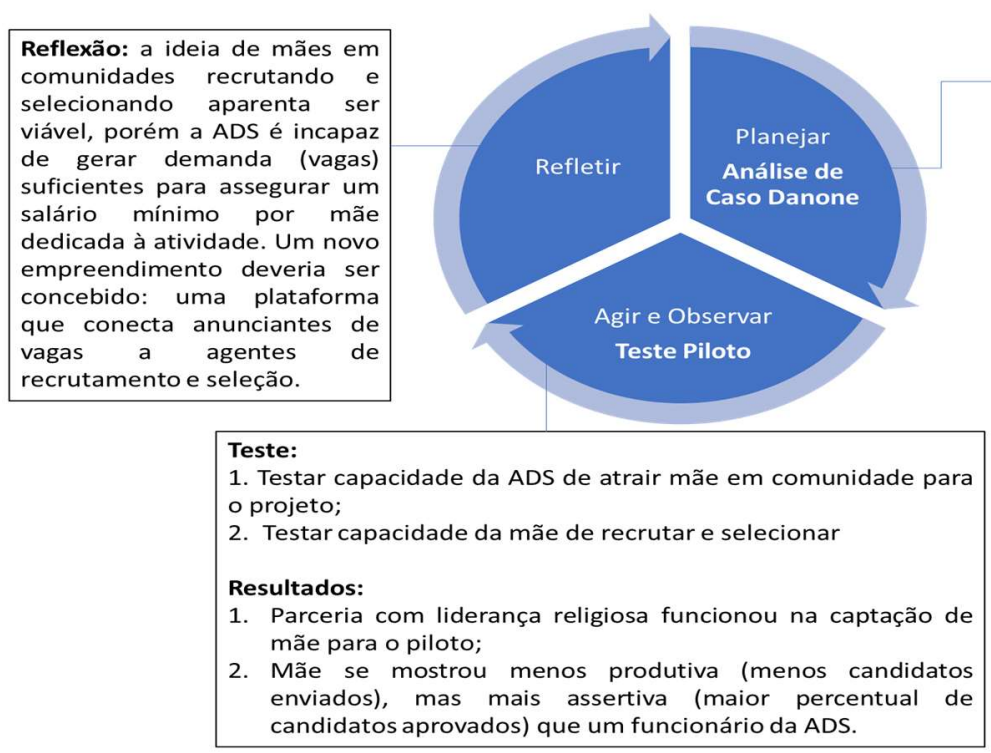

Projeto Kiteiras: mulheres em comunidades vendendo, de forma autônoma, kits de produtos Danone.

Principal dificuldade: não conseguiam captar mulheres dispostas a exercer atividade (sem conexão com o grupo impactado).

Fator de sucesso: entrada de ONG que passou a fazer a captação das mães (Visão Mundial). ONG já possuía ampla rede de contatos com lideranças nas comunidades.

Plano: parceria com ONGs ou lideranças locais para acessar mães nas comunidades.

Fonte: Elaborada pelo autor (2018)

\subsection{Segundo Ciclo}

\subsubsection{Narrativa}

\subsubsection{Planejamento do Modelo de Negócio}

Os cinco meses subsequentes ao teste da ADS foram dedicados à concepção conceitual do novo empreendimento. A ideia fundamental estava definida: a empresa seria uma plataforma onde se anunciam vagas e as vagas são distribuídas para as agentes de recrutamento, mas foi entendido pelos sócios da ADS que era necessário formular um modelo de negócio detalhado para esse novo empreendimento. Para a modelagem do negócio foi adotada a metodologia proposta por Pedroso (2016), considerando-se seis dimensões definidoras de um empreendimento (Figura 3).

\subsection{Modelo de Operação}

A primeira dimensão formulada foi o modelo de operação. A nova ideia fora concebida sobre um novo conceito de modelo de operação, e dessa forma entendeu-se que essa deveria ser a dimensão-base para a elaboração das demais. 
O modelo de recrutamento por rede (realizado por autônomos dentro de seus raios de contatos) era o cerne do conceito operacional, e as mães de crianças fora de idade escolar executando essa atividade eram o propósito social do empreendimento.

O empreendimento não seria uma consultoria, não executaria o serviço de recrutamento e seleção, seria uma plataforma tecnológica que permitiria aos seus usuários, as agentes de recrutamento, empreender a atividade de recrutamento e seleção de forma autônoma. O objetivo dessa mudança conceitual era aumentar a magnitude do negócio para uma escala que uma consultoria não alcançaria, alargando, assim, a amplitude do impacto social gerado. A operação do serviço contratado seria, de fato, executada pelas agentes de recrutamento. Caberia à empresa suportar o envio das informações e a geração da demanda de serviço em uma nítida configuração de modelo de negócio definida por Gassmann (2014) como orquestradora (Figura $10)$.

Figura 10 - Fluxo de atividades

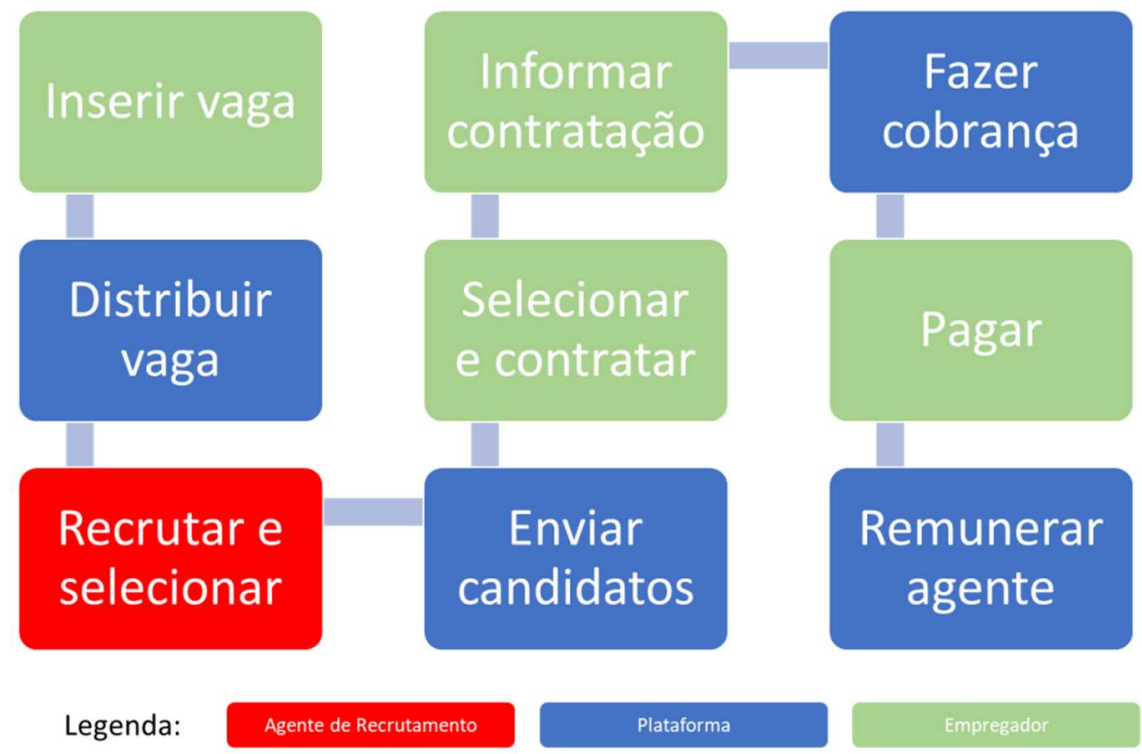

Fonte: Elaborada pelo autor (2017).

Para a captação de agentes de recrutamento, foram planejados dois estágios para atividade. Em um primeiro momento, a captação seria feita de forma ativa por meio de visitas às comunidades realizadas por uma profissional da empresa com a intermediação de lideranças locais, que funcionariam como facilitadores e catalisadores para aceleração de resultados. No segundo estágio, com a operação já madura, apostava-se que a notícia da oportunidade dentro das comunidades atrairia de forma espontânea novos usuários para a plataforma, que se cadastrariam diretamente pela interface da aplicação. 
Quanto à geração de demanda, a experiência dos sócios da ADS com a atividade de venda de serviço de recrutamento e seleção sempre foi pautada em reuniões comerciais formais conduzidas pelo sócio operador, com negociações de contratos e venda do serviço para médias e grandes empresas. Como o empreendimento demandaria esforço adicional para desenvolver um novo modelo de entrega do serviço, optou-se pelo modelo de venda já conhecido para simplificação do modelo de operação.

\subsection{Posicionamento Estratégico}

O posicionamento estratégico do novo negócio foi concebido após a definição do modelo operacional: primeiro se propôs o modo de entregar o serviço, depois se atentaria para o que seria o serviço a ser entregue. Isso ocorreu porque o modelo inclusivo da entrega do serviço é a essência do empreendimento e predefinidor de todos os modelos seguintes.

Quando a ADS testou o modelo de captação de candidatos através de rede de candidatos, ela possuía em sua retaguarda uma estrutura de pessoal capacitado que poderia fazer um duplo crivo dos profissionais selecionados, além de conduzir toda a comunicação entre candidatos e clientes ao longo do processo (agendamento de entrevistas, comunicação de aprovação, informação sobre documentação etc.). Essa estrutura compartilharia a responsabilidade de seleção e ainda excluiria a demanda de gestão dos processos por parte das mães. Sendo a ADS o último elo entre o candidato e o empregador, na prática a responsabilidade última da seleção recairia sobre ela. Nesse modelo, a atuação das mães era reduzida ao papel de recrutamento.

$\mathrm{Na}$ cadeia do setor de recrutamento e seleção, as atividades de recrutamento e seleção não estão necessariamente unificadas e têm valores bastante distintos. A Figura 11 ilustra arranjos observados dentro dessa cadeia e o modo como um empregador pode chegar até um candidato:

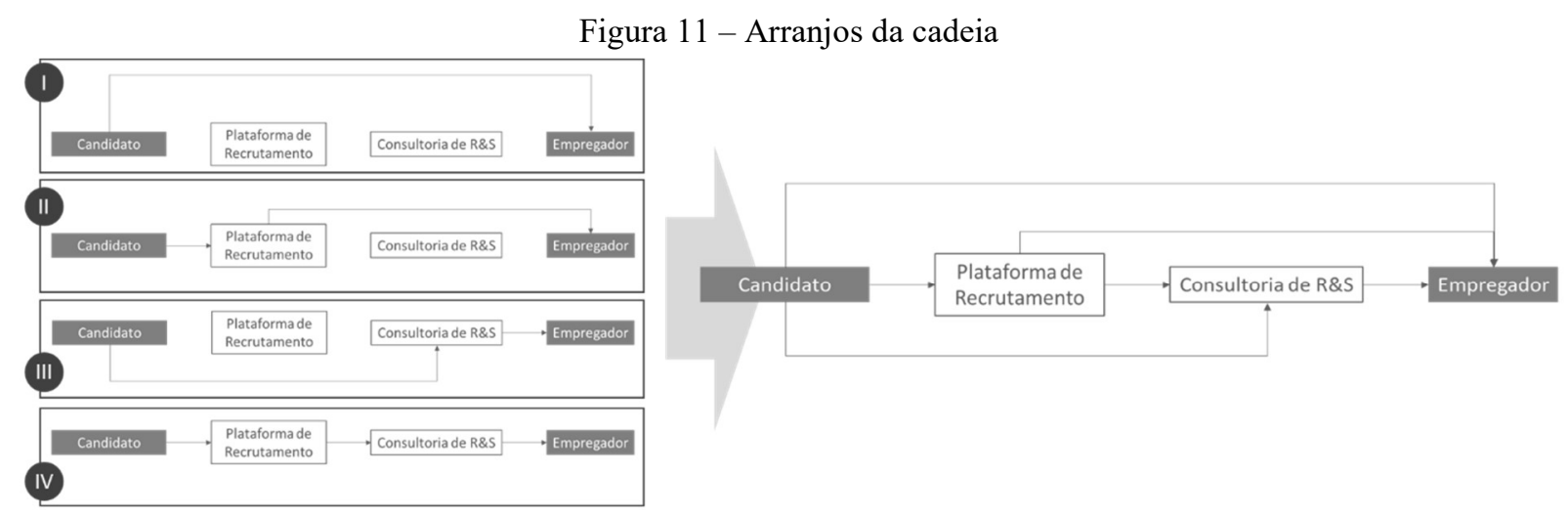

Fonte: Elaborada pelo autor (2017). 
A ilustração da Figura 11 apresenta quatro caminhos distintos para um empregador chegar até um candidato:

I. Nenhuma terceirização de atividades: o empregador recruta e seleciona sem assistências externa.

II. O empregador contrata o serviço de recrutamento e assume a responsabilidade pela seleção de todos os candidatos recrutados.

III. O empregador contrata o serviço de recrutamento e também o de seleção. Cabe a ele apenas a última seleção entre candidatos já pré-selecionados pela consultoria de recrutamento e seleção. Nesse caminho, a consultoria foi capaz não só de escolher os candidatos para seleção mas também de atraí-los com esforço próprio.

IV. Novamente o empregador contrata o serviço de recrutamento e seleção. Nesse caminho, a consultoria se apoia na plataforma de recrutamento para recrutar os candidatos que serão selecionados por ela.

A atividade de recrutamento consiste em atrair maior número de candidatos para uma vaga. É, essencialmente, uma atividade de mídia ou divulgação. Quanto maior a capacidade de difusão da mensagem (a vaga), maior a capacidade de captação de candidatos. Os candidatos, no entanto, não são necessariamente os profissionais qualificados para as posições. A experiência no mercado mostra que uma centésima fração das candidaturas são, de fato, de candidatos com as qualificações desejadas. É nesse momento que entra a seleção: selecionar os candidatos corretos entre as centenas ou os milhares de candidaturas demanda avaliação em massa de currículos, entrevistas por telefone e pessoais e, por vezes, avaliação mediante testes. Todo esse processo é feito de forma manual e é concluído por meio de uma lista de candidatos finalistas.

As diferenças de escalabilidade e custos das duas atividades se refletem no valor captado dentro da cadeia (Figura 12). As atividades de recrutar e selecionar um profissional para uma posição operacional têm, juntas, um valor de mercado que varia entre $50 \%$ e $70 \%$ do salário do profissional contratado (valor livre de impostos). Isto é, se o profissional for contratado por R\$ $1.000,00$, a remuneração pelo serviço será entre $\mathrm{R} \$ 500,00$ e R \$ 700,00 mais impostos a serem calculados. Há casos de valores muito inferiores a isso, entre R \$ 200,00 e R \$ 300,00, aplicados às empresas de call center, que contratam centenas de profissionais de atendimento com uma 
mesma consultoria, que conseguem otimizar despesas de recrutamento e simplificam a atividade de seleção reduzindo-a a um simples teste escrito de múltipla escolha.

A atividade de recrutar é significativamente mais barata. Anunciar uma vaga em uma plataforma de alta visibilidade custa $\mathrm{R} \$ 50,00$ para os pequenos anunciantes e chega a $\mathrm{R} \$ 15,00$ para os grandes anunciantes. O anúncio, no entanto, é por vaga e não por candidato contratado. Se uma empresa contrata o serviço de recrutamento e seleção de uma consultoria, ela paga por cada profissional contratado. Se ela contratar cinco vendedores, pagará o valor referente a cada um dos cinco vendedores contratados. Se essa mesma empresa for uma grande anunciante e pagar R\$ 15,00 pelo anúncio de vaga para vendedor, o investimento será dissolvido nas cinco posições preenchidas e não passará de $\mathrm{R} \$ 3,00$ por profissional contratado.

Figura 12 - Valores captados pelas atividades

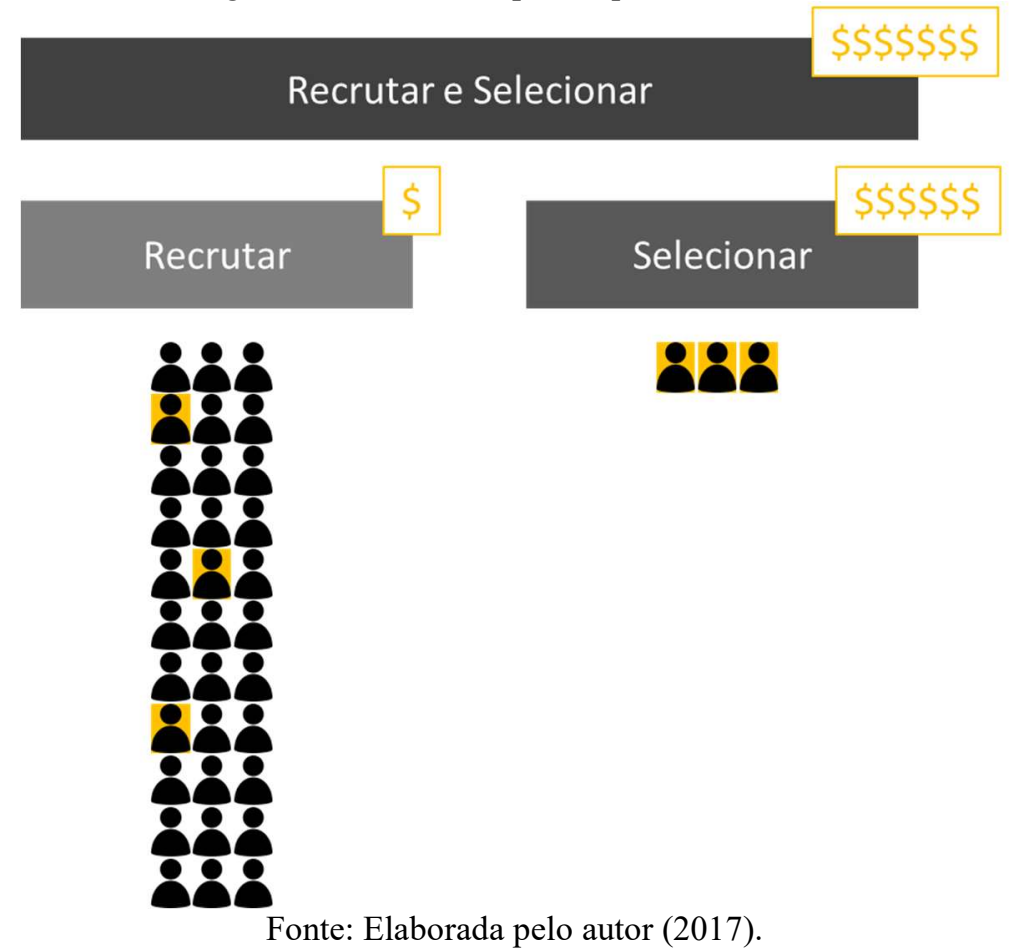

Tamanha discrepância entre o valor capturado por posição fechada através de uma plataforma de recrutamento e uma consultoria de R\&S é sustentada por dois fatores: o valor entregue (selecionar tem um valor percebido muito mais alto) e a escala (os caminhos II e IV são muito mais recorrentes que III).

Esse cenário de captura de valor foi determinante para a definição do posicionamento estratégico do negócio. Uma rede de mães em contato direto com candidatos tem ou gera mais valor em termos de eficácia na comunicação do que como amplitude. Entregar apenas recrutamento e competir com plataformas de recrutamento, a um custo que pode chegar a 
centavos por candidato contratado, parecia uma captura de valor irrisória e, acima de tudo, um desperdício de potencial. Essas mães, dentro de suas comunidades, poderiam criar uma comunicação ativa, assertiva e eficaz com os profissionais da região. Em uma atividade onde a eficiência é medida pela capacidade de identificar profissionais com baixo absenteísmo, sem histórico de curtas passagens por várias empresas e capaz de se comunicar em uma entrevista, elas poderiam entregar um serviço de seleção de qualidade superior usando o conhecimento pessoal que têm sobre cada candidato avaliado.

Definido que a plataforma se posicionaria como uma ferramenta para que as mães pudessem fazer o serviço de recrutamento e seleção em suas comunidades, o passo seguinte foi precificar o serviço prestado por elas. Com o propósito de simplificar o entendimento comercial por parte do contratante, e de remuneração por parte das mães, foi definido um valor fixo arbitrário para cada candidato contratado. Ao contrário da prática de mercado, o valor não variaria conforme o salário do candidato contratado e seria informado o montante bruto, e não líquido. Essas decisões foram feitas para simplificar a comunicação, principalmente com as mães. Essas mulheres não estão habituadas ao mercado de recrutamento e seleção, e quanto mais simples e transparente for o modelo de remuneração, mais crível será a plataforma.

Para precificar o serviço foi utilizado o salário-mínimo de São Paulo, R\$ 1.076,20 (GOVERNO DO ESTADO DE SÃO PAULO, 2017) e a taxa mínima comumente praticada é de 50\% para o cálculo. Considerando os impostos de aproximadamente 13\% sobre o valor bruto, o valor do serviço referenciado ficou em $\mathrm{R} \$ 618,51$. Também foram considerados os valores de R $\$ 1,00$ (empresas com múltiplas contratações para um único anúncio) e de $\mathrm{R} \$ 50,00$ (empresas que contratam um único profissional para um anúncio veiculado) para o serviço das plataformas de recrutamento para traçar o gráfico abaixo: 
Gráfico 1 - Curva de preços de referência

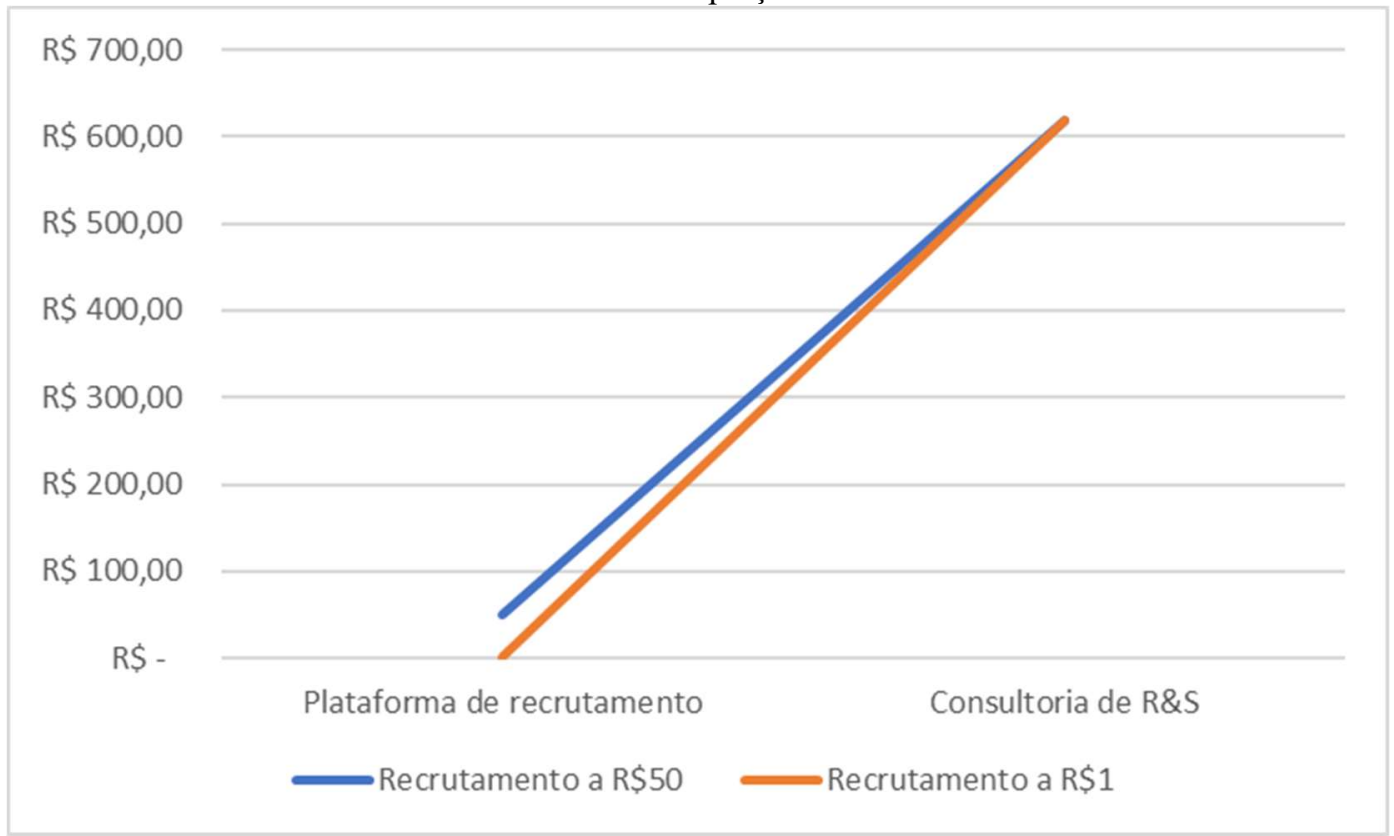

Fonte: Elaborado pelo autor (2017).

As retas do Gráfico 1 representam o aumento do valor captado pelo aumento do valor gerado, tendo em suas extremidades os serviços de consultoria R\&S e a plataforma de recrutamento. Considerando as curvas, qualquer posicionamento acima delas caracterizaria sobrepreço, ou seja, captura de valor acima do valor criado e baixa competitividade comercial. Um posicionamento abaixo caracterizaria subpreço, captura de valor inferior à gerada e alta competitividade comercial. Foi determinado que o negócio deveria aproveitar seu modelo de baixo custo operacional e se posicionaria significativamente abaixo das curvas, cobrando R\$ 250,00 bruto por candidato contratado e entregando um serviço de recrutamento e seleção de qualidade superior (Gráfico 2). Ficou entendido como serviço de recrutamento e seleção de qualidade superior um serviço mais rápido (I), eficaz (II) e inteligente (III). A rapidez seria assegurada pelo volume de mães engajadas em encontrar o perfil buscado, o que poderia fechar uma lista de candidatos em horas. A eficácia viria da proximidade dessas mães com os candidatos, que permitiria reduzir a assimetria de informação entre empregador e candidato (informações omitidas pelos candidatos aos empregadores). Por último, a inteligência ficaria por parte da plataforma, que aproximaria geograficamente emprego e empregado ao direcionar para cada mãe apenas as vagas próximas a elas. 
Gráfico 2 - Posicionamento definido

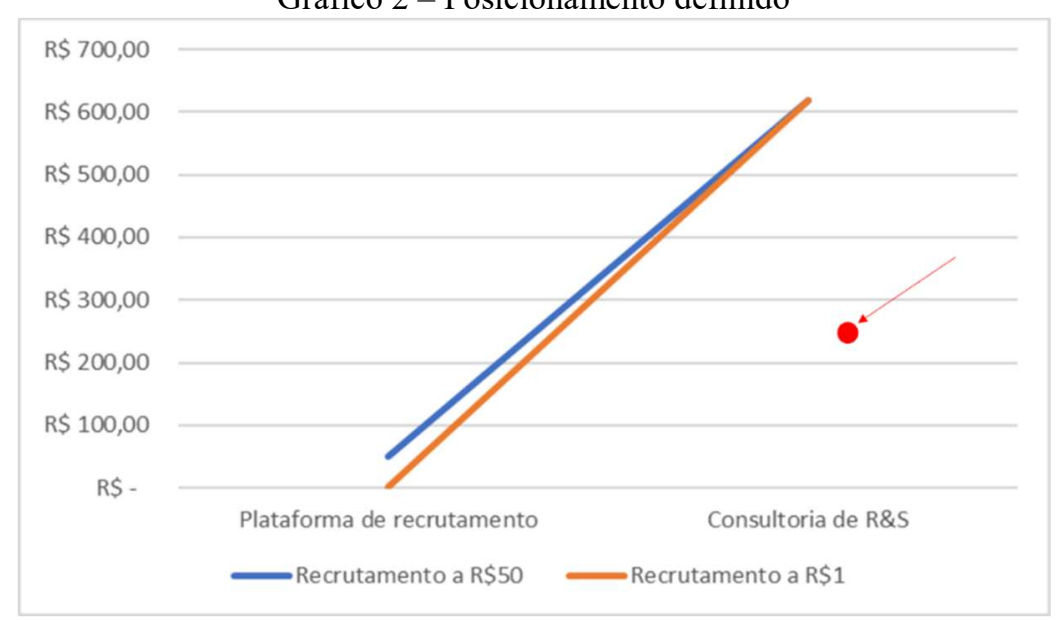

Fonte: Elaborado pelo autor (2017).

A proposta ambicionava alcançar o conceito de inovação de valor (KIM; MAUBORGNE, 2005) reduzindo custos inerentes ao mercado que atua (aluguel, plataformas de recrutamento, telefonia e pessoal) ao mesmo tempo que cria elementos nunca antes ofertados por esse mercado (velocidade, assertividade e proximidade geográfica) (Figura 13).

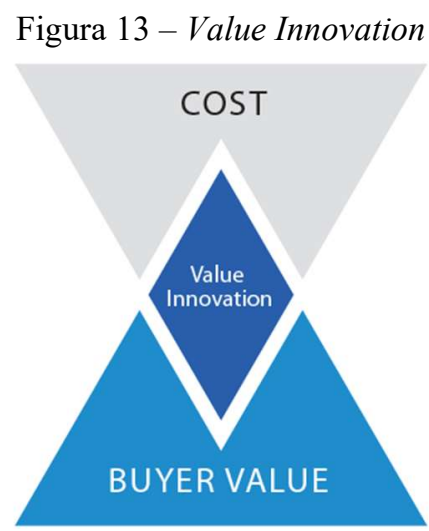

Fonte: Blue Ocean Strategy (KIM; MAUBORGNE, 2005).

Após definição do posicionamento estratégico pela ótica do empregador (valor entregue ao empregador) e pela ótica do investidor (inovação de valor e valor captado), os sócios revisitaram o pilar social e seu posicionamento estratégico pela ótica das mães. Por se tratar de um negócio inclusivo estruturado em um modelo de negócio peer to peer, onde o empreendimento assume o modelo de orquestrador da cadeia de valor (GASSMANN; FRANKENBERGER; CSIK, 2014), o posicionamento estratégico deve contemplar as perspectivas do gerador de demanda (pilar financeiro da cadeia: o empregador), do gerador de oferta (pilar operacional: as mães) e o investidor (viabilizador do empreendimento). 
A inovação de valor idealizada impacta positivamente o empregador, que recebe um serviço de maior valor (maior velocidade, maior assertividade e profissional residindo mais próximo do emprego) pagando menos, e o investidor, que detém um modelo de negócio único e altamente competitivo. No entanto, a inovação de valor não assegura o valor social gerado, isto é, não assegura que o elo da oferta do serviço, as mães, captará suficiente valor dentro da cadeia. O modelo operacional proposto, quando em desequilíbrio, pode gerar um desbalanceamento entre oferta e demanda e, sendo a oferta muito superior à demanda, o volume médio de vagas fechadas por cada mãe seria insuficiente para assegurar uma renda mínima.

Com o propósito de estabelecer uma meta de valor social gerado, e aqui o valor social é reduzido apenas ao valor econômico captado pela mãe, foi definido que a plataforma deveria criar condições para que uma mãe com alto nível de dedicação à atividade deveria ser capaz de produzir a riqueza de ao menos um salário-mínimo por mês.

\subsection{Modelo de Clientes}

A plataforma planejada tem um único cliente em seu modelo comercial: as agentes de recrutamento e seleção. Trata-se de uma ferramenta de trabalho que permite às mães empreenderem seus esforços na atividade de recrutamento e seleção e entregarem o serviço a seus clientes. Nesse arranjo, o empreendimento é um serviço que contempla a solução tecnológica (inserção de vagas de um lado e envio de candidatos de outro) e financeira (cobrança pelo serviço, pagamento de impostos e distribuição dos valores). Apesar de os empregadores serem os clientes das agentes de recrutamento, e não da plataforma, como a plataforma assumiu a responsabilidade de gerar a demanda houve a necessidade de estruturar o modelo de clientes a serem atendidos pelas agentes de recrutamento.

O posicionamento estratégico da empresa abriu a oportunidade de, além de as agentes de recrutamento disputarem o mercado atual com alto nível de competitividade, também alcançarem potenciais consumidores que ainda não utilizam o serviço e, ainda, competirem no mesmo mercado das plataformas de recrutamento.

Foi definido que a empresa, por ter necessidade de maximização na geração de demanda, buscaria como clientes tanto os empregadores como as consultorias de R\&S.

Oferecer a empresa para consultorias de $R \& S$ como alternativa às plataformas de recrutamento não seria uma atividade simples porque, além de mais cara, ainda poderia ser vista como concorrente direto, e de fato era. Apesar de as plataformas de recrutamento já oferecerem suas soluções diretamente aos empregadores (Figura 11), a proposta de valor oferecido por uma 
plataforma de recrutamento (anúncio de vaga e captura de centenas de currículos) é diferente da oferecida pelas consultorias de R\&S (recrutamento, seleção e entrega de uma pequena lista de candidatos aprovados). A proposta do serviço entregue pelas agentes de recrutamento é muito próxima a uma consultoria de $\mathrm{R} \& \mathrm{~S}$ e, portanto, dificilmente seriam aceitas como parceiras pela consultoria. O primeiro passo para testar esse conceito seria a própria ADS. Devido ao sobrepreço da ADS quando comparado ao serviço das agentes de recrutamento, era possível a ela, em teoria, utilizar o serviço como recurso para aumento da produção. Essa produção adicional entraria como receita marginal e, mesmo que a alto custo, a receita marginal seria superior à despesa marginal e criaria valor econômico para a empresa. Este cenário só é viável em situação onde a receita sofre restrição pela capacidade produtiva limitada, cenário vivido pela ADS depois de se reposicionar como uma consultoria de recrutamento e seleção de pessoas com deficiências (possuía vagas acima de sua capacidade de encontrar candidatos).

As dificuldades de oferecer o serviço a empresas de R\&S fazia com que o mercado de empregadores se apresentasse como a maior oportunidade. Para planejar esse mercado-cliente, foram utilizados dois grupos com três variáveis cada, combinadas em uma matriz $3 \times 3$. O primeiro grupo, distribuído nas colunas $\mathrm{A}, \mathrm{B}$ e $\mathrm{C}$, foi dividido entre as variáveis médias e grandes empresas (MGE), micro e pequenas empresas (MPE) e pessoa física (PF). O segundo grupo, distribuído nas linhas 1,2 e 3, foi preenchido por variáveis que definiam o comportamento de consumo de serviços concorrentes: usuário de plataforma de recrutamento (UPR), cliente de consultoria de R\&S (CC) e nunca utilizou serviços desta natureza (nenhum). Os nove quadrantes analisados podem ser conferidos na Tabela 3.

Tabela 3 - Matriz de clientes empregadores

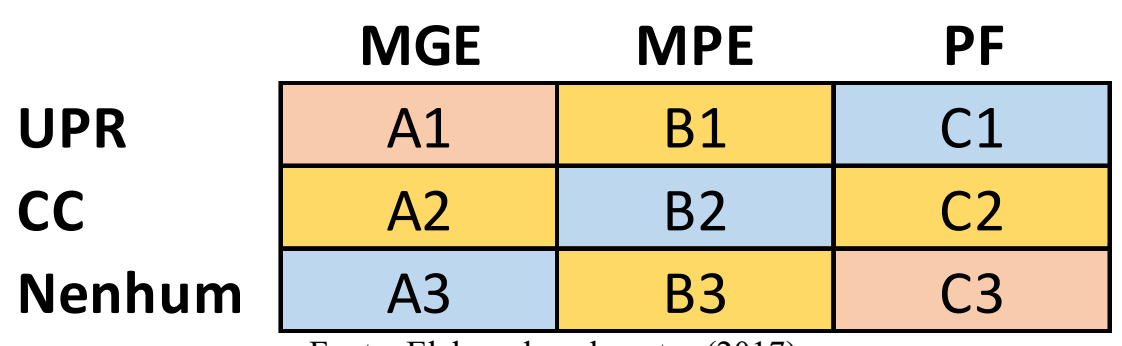

Fonte: Elaborada pelo autor (2017).

Os sócios, ao avaliarem a matriz, definiram pela sua experiência no mercado que os extremos A1 e C3 eram as zonas de comportamento predominante na primeira e na terceira colunas. As médias e grandes empresas comumente possuem equipe de recursos humanos própria, que faz uso de plataformas de recrutamento para obter currículos e realizar processos seletivos internos. É menos comum essas empresas terceirizarem o serviço de seleção para uma 
consultoria de R\&S (salvo momentos da economia onde é sentida escassez de mão de obra) e ainda menos comum não utilizarem qualquer ferramenta externa para captar currículos. $\mathrm{O}$ inverso foi afirmado quando avaliado o mercado de pessoa física. Trata-se de um mercado onde impera a indicação pessoal de profissionais, com algumas soluções de consultoria de R\&S já sendo ofertadas para posições específicas (faxineiras e babás) e quase nenhuma presença de indivíduos anunciando em plataformas de recrutamento para fazerem, pessoalmente, longo processo de seleção em grande base de currículos recebidos.

As micro e pequenas empresas mostraram o agrupamento mais heterogêneo dentro da distribuição. Ficou entendido que as microempresas se comportam de maneira muito próxima à pessoa física, tendo baixíssimo uso de qualquer solução, enquanto as pequenas empresas já utilizam plataformas de recrutamento para aumentar a produtividade em seus processos. A conclusão é que o serviço das consultorias de R\&S não é uma opção, possivelmente pelo custo alto percebido frente ao preço.

Para cada um desses clientes foi analisado o modo como o serviço poderia ter valor ou gerar valor e, consequentemente, qual seria a estratégia comercial a ser adotada.

Em A1, o serviço representa aumento de custo, barreira já enfrentada pelas consultorias de R\&S, além da competição com a própria equipe interna de $R \& S$ da empresa. Essas duas barreiras, custo e conflito interno, sempre foram os maiores impeditivos comerciais para as consultorias, como já foi vivenciado pela ADS, e a nova solução sofreria a mesma resistência se não apresentasse nova proposta de valor. Para esse grupo de empregadores foi definido que o valor a oferecer não deveria ser o econômico, calcado em uma seleção ágil, mas sim o valor intangível, ou seja, o pilar social no qual o negócio se sustenta. Para essas empresas a abordagem seria o negócio como opção dentro da estratégia de sustentabilidade social e impacto na cadeia através de fornecedores estratégicos. Para vender essa solução, seria preciso um interlocutor altamente qualificado para transmitir a mensagem e abordar profissionais nas empresas que ou fossem responsáveis pelo tema sustentabilidade (gerente de sustentabilidade ou responsabilidade social), ou fossem de uma hierarquia suficientemente alta para ter esse tema dentro de seus compromissos (diretores de recursos humanos e presidentes).

Para A2, o cenário onde médias e grandes empresas utilizam consultorias de $R \& S$, não há barreira quanto ao serviço. Há duas formas distintas de acessar esse mercado, através da proposta de valor social ou puramente econômica. A primeira, apesar de aumentar o valor percebido pelo negócio, é mais complexa e demanda da outra parte sensibilização para o tema. A segunda é simples, direta e o argumento está a favor do novo empreendimento. O serviço é mais barato que aquele que as empresas desse grupo já contratam, e não há risco em caso de 
insucesso, uma vez que a remuneração é apenas no caso de sucesso (se o candidato for contratado). Foi definido que esse grupo receberia a abordagem mais racional e econômica: somos mais baratos do que a concorrência, no teste.

Em A3, onde os sócios desconhecem empresas nesse grupo, foi definida abordagem como em A1.

As micro e pequenas empresas que utilizam plataformas de recrutamento, o quadrando B1, são empresas que precisam de recurso externo para o volume de contratações que demandam, mas que não são atendidos pelas consultorias de R\&S por seus altos custos. Os anúncios contratados por esse grupo custam $R \$ 50,00$ ou mais, são pagos independentemente do sucesso do processo de seleção e a própria seleção é executada por profissionais das empresas, comumente não especializados no tema. Além do tempo dedicado ao trabalho paralelo de recrutamento e seleção (geralmente executado pelo próprio proprietário), há custos de telefonia envolvidos no processo. Os processos são, como experimentados dentro das consultorias de R\&S, improdutivos (muitos currículos e muitas ligações) e repletos de decepções (candidatos que desistem e não comparecem a entrevistas). Para esse grupo o valor a ser ofertado é o valor de uma consultoria de R\&S, porém a um custo acessível. O serviço entra como uma solução que permite ao proprietário do estabelecimento focar-se em suas atividades centrais, poupando esforços e frustrações recorrentes com recrutamento e a um custo mais próximo do serviço que já utiliza (plataforma de recrutamento) do que do serviço que não pode contratar (consultoria de R\&S).

Ao quadrante B2 também entendido, pela experiência dos sócios, como pouco comum no mercado. Micro e pequenas empresas não têm o hábito de terceirizar a atividade de recrutamento e seleção ao custo de consultorias. Para o caso foi determinado que seria utilizado o mesmo argumento de venda de A2, ou seja, focar-se em preço como fator de decisão pelo serviço e oferecê-lo ao proprietário do estabelecimento.

Ao grupo de micro e pequenas empresas que não utilizam nem soluções para recrutamento nem para seleção (B3) foi estabelecido o desafio de ofertar o serviço pelo seu aspecto funcional: um serviço de R\&S. A abordagem é similar a A1, porém o desafio é maior por este grupo ainda não ter sido convertido nem mesmo pelas plataformas de recrutamento. São empresas que contratam por indicações, e não há qualquer despesa atrelada ao tema. Ficou entendido que esse comportamento é mais predominante em microempresas do que pequenas empresas e que está muito mais próximo de uma cultura de contratação de pessoa física do que 
de uma pessoa jurídica de médio porte. O desafio aqui seria introduzir o tema e apontar os benefícios de uma seleção ampla frente a uma contratação por restrição de opções.

As contratações feitas por pessoa física são um mercado ainda muito pouco explorado pelos serviços de recrutamento e de seleção, mas já existem soluções pontuais focadas em atividades exercidas, principalmente para faxineiras e babás. Essas empresas oferecem um serviço focado, não experimentado pelos sócios, mas percebido como altamente qualificado. Os sócios definiram que o mercado de pessoa física, ainda pouco explorado, seria um mercado estratégico para o médio prazo do negócio, mas não para o lançamento. O esforço adicional para a criação de um mercado novo, ao mesmo tempo que se estrutura um modelo operacional novo, poderia inviabilizar e desfocar a operação, prejudicando ganhos rápidos de curto prazo. Para a pessoa física que utiliza plataforma de recrutamento $(\mathrm{C} 1)$, seria ofertada uma proposta como em B1; para aqueles que utilizam consultoria de R\&S, seria ofertado o valor social da proposta, como em A1; e para aqueles que se apoiam somente em indicações para contratações a abordagem deveria ser como em B3.

A Tabela 4 apresenta os valores a serem oferecidos a cada tipo de cliente mapeado.

Tabela 4 - Valores oferecidos por tipo de cliente

\begin{tabular}{|c|c|c|c|c|}
\hline & MGE & MPE & PF & Pilar comercial \\
\hline UPR & A1 & B1 & $\mathrm{C} 1$ & Valor social \\
\hline $\mathrm{CC}$ & $\mathrm{A} 2$ & B2 & $\mathrm{C} 2$ & Valor funcional \\
\hline Nenhum & A3 & B3 & C3 & Valor econômico \\
\hline
\end{tabular}

\subsection{Modelo Econômico}

A plataforma, como idealizada, é uma ferramenta de trabalho para as agentes de recrutamento que, além da solução tecnológica e financeira, também entrega o benefício da geração de demanda pelo serviço das mães. A receita da plataforma está ligada ao pagamento por esse serviço pelas agentes de recrutamento. Como não há um intuito de gerar comprometimento financeiro das mães com a plataforma de tal modo que se pudesse criar uma situação de déficit por elas, a ferramenta só cobra o valor de utilização quando a mãe também é remunerada. Em síntese, a plataforma também tem a sua remuneração baseada no sucesso da atividade da agente de recrutamento. Para isso ser viável, foi precificada a partir do valor definido por profissional contratado, $\mathrm{R} \$ 250,00$, menos o valor líquido entendido como remuneração-alvo para a agente de recrutamento, $\mathrm{R} \$ 150,00$. A definição do valor líquido a ser 
capturado pela agente foi feita de forma arbitrária, mas considerando a capacidade de uma mãe dedicada à atividade de fechar ao menos sete vagas em um mês e obter um salário-mínimo.

O valor bruto de $\mathrm{R} \$ 250,00$, deduzido $\mathrm{R} \$ 15,00$ de impostos (Simples), R \$ 4,00 de custos de cobrança (boleto) e $\mathrm{R} \$ 30,00$ de despesas bancárias (pagamento à ordem, modelo de pagamento para público desbancarizado), deixaria $\mathrm{R} \$ 51,00$ para a plataforma por vaga fechada ( $20 \%$ do valor transacionado).

Quando avaliamos a plataforma pela ótica do serviço de recrutamento e seleção ofertado na ponta, o modelo econômico assume o padrão de mercado de consultorias de recrutamento e seleção na forma da cobrança, cobrando por cada candidato contratado. A forma de precificação, no entanto, se assemelha às plataformas de recrutamento: valor fixo para qualquer vaga e precificado já com os impostos contemplados.

\subsection{Modelo de Gestão}

Após definição dos modelos de operação, de clientes, econômico e posicionamento estratégico, os sócios entenderam que tinham um modelo de negócio minimamente definido. $\mathrm{O}$ próximo passo seria solucionar uma restrição maior: quem seria o sócio operador do negócio?

Como todo novo empreendimento, o modelo de gestão está intimamente ligado ao perfil do empreendedor à frente do negócio; portanto, seria improdutivo debater o tema sem antes definir a pessoa.

Nenhum dos sócios da ADS tinha disponibilidade para conduzir o novo empreendimento; todos estavam dedicados em tempo integral a outras atividades e chegaram ao ponto de terem um projeto, mas não terem um executor. A própria ADS já operava com administração a distância pelo sócio majoritário e execução do dia a dia por um profissional chefe da operação. Esse modelo foi considerado, porém havia uma grande diferença entre administrar a distância um negócio já operacional e iniciar uma operação a distância. Todo empreendimento tem alto risco de insucesso; um negócio inclusivo tem o desafio adicional de entregar valor social enquanto busca sustentação financeira, e arriscar um novo empreendimento com gestão a distância pareceu aos sócios uma forma certeira de perder o investimento e falhar com as mães.

A solução surgiu através de um amigo em comum aos sócios, um engenheiro eletricista especialista em desenvolvimento de sistemas. Em fevereiro de 2017 ele estava em processo de saída de seu segundo empreendimento e em busca de um novo projeto, sendo, portanto, o nome 
perfeito para o desenvolvimento técnico da plataforma. Apresentado ao projeto, ele imediatamente se encantou com a ideia e se prontificou a desenvolver a plataforma, participar do investimento e conduzir a operação, se tornando sócio e executivo-chefe da empresa.

Com o novo sócio foi possível definir um modelo de gestão a ser implantado, ele seria responsável pela gestão da operação e iria dispor de uma consultora de campo para captar mães nas comunidades e lhes levar a ideia do empreendimento. Acumularia as responsabilidades da operação de recrutamento e seleção (gestão da agente de campo) e do desenvolvimento técnico da plataforma. Ao sócio mais experiente da ADS caberia a responsabilidade pelo planejamento estratégico, pela gestão financeira (e futura captação de novos investimentos), pelas primeiras vendas para clientes estratégicos e pelo aconselhamento diário sobre a operação, além da rotina semanal de reunião entre sócios para fechamento de ciclo curto de aprendizado (modelo de inovação).

\subsection{Modelo de Inovação}

Os modelos de inovação e gestão mostraram grande inter-relação conceitual, sendo difícil separar um do outro. Uma startup é um empreendimento em constante mutação e, portanto, fazer sua gestão é gerir a mudança, a inovação.

As características mais marcantes do modelo de inovação definido pelos dois gestores são o ciclo semanal de aprendizado e correção tática e o ciclo mensal de aprendizado e correção estratégica. Todo início de mês um objetivo seria traçado para a operação, e ao longo das semanas as táticas para alcançá-lo seriam ajustadas conforme os resultados obtidos. Esse modelo de gestão adota o conceito de ciclos de aprendizado rápido proposto por Ries (2011), percorridos ao longo de três etapas: idealizar, testar e medir.

\subsection{O papel da ADS}

Em março de 2017, após a entrada do novo sócio no projeto, foi elaborado o primeiro planejamento de investimento da empresa. Pela primeira vez os sócios fizeram um plano de investimento cujo capital próprio não seria suficiente para a viabilização do empreendimento. O modelo de negócio tem uma margem de contribuição comercial bastante reduzida para cada transação e demanda alta escala para atingir receita compatível com os custos operacionais projetados (servidores, manutenção de tecnologia, equipe de campo e retaguarda 
administrativa). Além do desafio do equilíbrio financeiro alcançado apenas com uma operação de alta escala, o próprio alcance da alta escala é o desafio maior.

Em modelos de negócios que buscam conectar a oferta e a demanda de um serviço, ou modelos orquestradores (GASSMANN; FRANKENBERGER; CSIK, 2014), alcançar o equilíbrio entre oferta e demanda requer alto investimento. As empresas mais bem-sucedidas nesse modelo de negócio, como Uber e Airbnb, asseguram a oferta do serviço antes de iniciarem a criação da demanda, e muitas vezes isso significa comprar capacidade ociosa ao custo de um alto volume de capital.

O desafio do lançamento de uma plataforma com o modelo de orquestrador (GASSMANN; FRANKENBERGER; CSIK, 2014) está em alcançar o equilíbrio entre oferta e demanda. No início da operação o desbalanceamento entre a oferta e a demanda de serviço pode ocasionar ora a desistência do cliente por uma necessidade não atendida (demanda maior que a oferta), ora o abandono da plataforma pelo prestador de serviço devido à baixa demanda pelo que é ofertado. Em uma operação de grande escala, oferta e demanda se ajustam em um cenário de preços fixos ou alternam preços e também encontram o equilíbrio. Em uma operação nascente isso não é possível e uma das pontas deve ser garantida pela plataforma.

Os grandes sucessos nesse modelo de negócio asseguram a oferta do serviço para então gerar a demanda, uma vez que seus mercados de consumo são amplos e abertos à competição. A garantia da oferta significa compra de capacidade produtiva, mesmo que seja para mantê-la ociosa. O Uber, quando entra em um novo mercado, começa pela arregimentação de motoristas e lhes assegura uma renda mensal fixa para que eles estejam disponíveis nos horários predefinidos pela plataforma. Uma vez assegurado o serviço de transporte, a plataforma começa o seu trabalho de geração de demanda (atração de passageiros).

O custo de comprar capacidade produtiva é alto, pois há grande risco trabalhista no modelo e ainda pode gerar confusão quanto ao conceito do negócio. Se o empreendimento optasse pelo caminho da disponibilidade de oferta, demandaria um capital de que os sócios não dispunham para arregimentar e remunerar agentes de recrutamento pela Grande São Paulo. Outra particularidade do negócio é que, para o Uber, basta a CNH e o documento do carro para saber que o indivíduo tem condições de prestar o serviço, visto não haver grande risco na compra da oferta. Para o empreendimento estudado, ser mãe não é condição suficiente para assegurar que a agente está apta para fazer recrutamento e seleção; não há garantia da oferta independentemente da remuneração assegurada. A remuneração fixa mensal também poderia gerar obrigações trabalhistas para a empresa, algo com que os sócios não conseguiriam arcar 
dada a restrição do capital investido. Por último, e mais importante, a remuneração fixa mensal seria um alento para as mães escolhidas para o projeto, mas passaria uma mensagem equivocada sobre o propósito do projeto. O projeto se propõe instrumentalizar as mães e possibilitar que elas empreendam o próprio esforço para conquistar renda de forma autônoma. A remuneração fixa poderia confundir a mensagem sobre o projeto, que se assemelharia mais à inclusão dessas mães no mercado de trabalho do que de empoderamento através do empreendedorismo individual.

Dadas as restrições de assegurar a oferta, a ADS se apresentou como a solução para garantir a demanda mínima para o início da operação. O novo empreendimento já nasceria com a ADS como cliente, todas as vagas desta seriam disponibilizadas na plataforma e a novas agentes de recrutamento já teriam, de imediato, uma demanda pelo seu serviço. Nesse modelo, similar ao modelo IV da Figura 11, a ADS contaria com o serviço das agentes de recrutamento para buscar seus candidatos e faria uma última seleção dos candidatos antes de os enviar para seus clientes. Para a ADS, era uma oportunidade de ganhar produtividade e aumentar o percentual de vagas fechadas em um mês. Para o novo empreendimento, seria não só uma demanda viabilizadora do início da operação como também um parceiro avaliador do nível do serviço prestado pelas agentes de recrutamento. A ADS continuaria com sua equipe trabalhando em paralelo para assegurar o serviço na ponta e não perder o pilar de sustentação da cadeia: o empregador.

\subsection{O Desenvolvimento da Marca}

Todos os empreendimentos que os sócios haviam feito até então, todos B2B, seguiam o mesmo racional: nenhum investimento em comunicação, mínima despesa fixa, construção do negócio através de esforço constante de venda ativa. Esse modelo gerava menor consumo de capital inicial dos empreendimentos, mas a ausência de investimento em comunicação demandava maior esforço comercial para abertura de mercado. Ao final, a empresa troca a possibilidade de um sucesso acelerado, sob o risco de insucesso, pelo rápido consumo de caixa, pela segurança da perpetuidade de uma operação que cresce de forma moderada.

O novo empreendimento, ao contrário dos anteriores, demandava alto capital para estabilização de demanda e oferta do serviço. Para capturar tamanho capital era preciso atrair investidores em curto espaço de tempo, dezoito meses. Os sócios entenderam, além da construção do modelo operacional, que o investimento em marca também seria relevante para tornar o negócio atrativo para investidores. 
O processo de escolha de nome da empresa foi longo e meticuloso. Buscava-se um nome não óbvio, que não restringisse a plataforma a currículos, vagas ou recrutamento, um nome que satisfizesse a dois públicos bastante distintos, os anunciantes de vagas e as agentes de recrutamento, que tivesse uma pronúncia universal, suficientemente agradável para o primeiro público e fácil para o segundo, que transmitisse calor e força, não fosse masculina e nem se restringisse ao universo de tecnologia. O processo de escolha do nome foi um exercício de brainstorming envolvendo os sócios e o profissional contratado para o serviço. Mais de duzentos e cinquentas nomes foram listados, cada participante do processo escolheu os cinco que mais lhe agradava, testes de registro de marca, domínio na internet. Pesquisas de empresas homônimas foram feitas e chegou-se a seis nomes finalistas. Uma pesquisa com mais de cinquenta mulheres de diferentes classes sociais foi feita usando-se os nomes finalistas e diferentes imagens relacionadas com o negócio. Ao final do exercício havia um nome escolhido: Kunla.

Kunla é redução de kunlaborado, que significa colaboração em Esperanto, uma língua artificial, sem identificação política, étnica ou religiosa. A pronúncia foi testada em diversas línguas, quase todas com a mesma sonoridade. Para os sócios, era um nome feminino e forte, como as mulheres que ele representa. $\mathrm{O}$ domínio escolhido para a plataforma foi kunla.social e, assim, o “.social” passaria a integrar a comunicação da plataforma junto com Kunla.

O passo seguinte, após a escolha do nome, era criar a imagem de Kunla, a logotipia e toda a sua comunicação visual. Nessa etapa os sócios apenas definiram o que gostariam que fosse transmitido, cabendo ao profissional de design o trabalho de concepção da solução. O que se esperava era que a comunicação sustentasse a força do nome enquanto equilibrava calor e ternura (sem clichês) e ainda transmitisse valores como superação, empoderamento, desenvolvimento e liberdade.

A proposta aprovada e executada traz a Kunla em fonte terrosa, em caixa baixa e com traços fortes, porém elegantes (Figura 14). É a força da grafia, mas sem excessos. A extensão ".social" assume uma fonte leve e reduzida em caixa alta, exercendo um papel secundário de comunicação do domínio com delicadeza suficiente para não sobrecarregar a marca. $\mathrm{O}$ elemento mais significativo é a borboleta, sutilmente posicionada sobre o "a" da Kunla. A borboleta, com traços acentuados de um "k", compartilha o tom terroso da fonte, mas predominam o amarelo e o magenta das asas, responsáveis pela transmissão da sensação de calor da marca. A própria borboleta, elemento planejado para ser exaustivamente utilizado na comunicação da Kunla, era a resposta para o desejo de transmissão de ternura, superação, 
desenvolvimento e liberdade. Sua metamorfose, seguida pelo leve e formoso voo, é a representação da transformação e da libertação que a plataforma ambiciona proporcionar às mães nas comunidades.

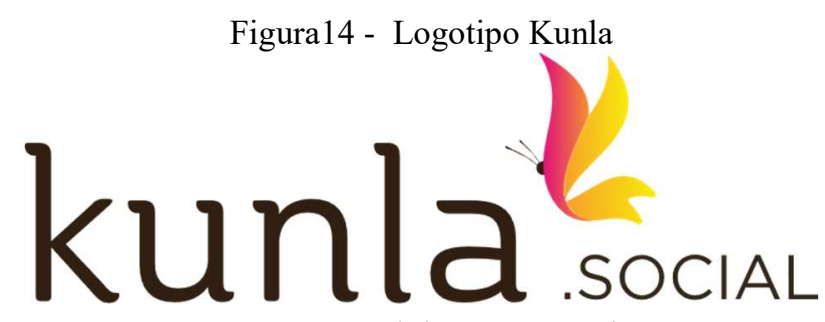

Fonte: Manual da marca Kunla.

4.2.1.1.9 O Desenvolvimento da Aplicação

Após a definição da marca e a comunicação visual da Kunla, o passo seguinte foi iniciar o desenvolvimento da plataforma, que contempla o site e a aplicação.

O site institucional foi o primeiro a ser desenvolvido. Foi concebido com um duplo propósito, vender e informar, nesta ordem. O site possui duas áreas, a página inicial tem o papel de vender, comunica de forma objetiva os motivos pelos quais um empregador deveria anunciar na plataforma e traz a chamada de "anunciar" como a ação central da página. A segunda área, "Saiba mais", exerce o papel de elucidar o modelo de negócios, detalhar a proposta de valor, o modelo financeiro e a rede de agentes. O site é simples e utiliza elementos visuais para elucidar o modelo de negócios (Anexo A).

Concluído o desenvolvimento do site institucional, os trabalhos migraram para o desenho da experiência do usuário da plataforma. Todo o fluxo de utilização da plataforma foi delineado, tanto para os anunciantes quanto para as agentes de recrutamento (a plataforma tem duas dimensões de usuários, o demandante do serviço e o prestador do serviço). As informações que fluem dentro da plataforma são a vaga, no sentido anunciantes para agentes de recrutamento, e candidatos, no sentido agentes de recrutamento para anunciantes. Dentro da dimensão do usuário anunciante, a experiência almejada de uso era ter uma vaga anunciada com a menor burocracia possível. Para a dimensão do usuário prestador do serviço, a interface deveria ser extremamente simples e limpa, com poucos elementos textuais e um mínimo de telas. Para ambos os usuários, portanto, a plataforma deveria primar pela minimização, pela mínima quantidade de telas e de ações requisitadas para se concluir o ciclo. 
O desenho do fluxo e dos elementos gráficos das telas sofreu grandes atrasos: o projeto ficou estagnado por dois meses, aguardando a evolução desses desenvolvimentos. No final de maio de 2017, cinco meses após o início dos trabalhos de planejamento do empreendimento e desenvolvimento da plataforma, a Kunla tinha um plano, investimento, sócio operador, um site institucional e telas de uma plataforma ainda a ser programada. Foi nesse momento, ainda sem a plataforma e cientes do quanto ainda demoraria para tê-la, que os sócios decidiram iniciar a operação. A plataforma não estava pronta, mas os prazos já se haviam estendido muito e os sócios sentiam a necessidade de começar a operar em escala reduzida para iniciar os ciclos rápidos de aprendizado. 


\subsection{Primeiro Mês de Operação}

No mês de junho de 2016 a Kunla fez a sua operação inaugural. O primeiro ciclo de teste operacional da Kunla partiu do modelo de negócio elaborado (Figura 15) e objetivava executar e avaliar os conceitos destacados em negrito.

Figura 15 - Modelo de negócio planejado

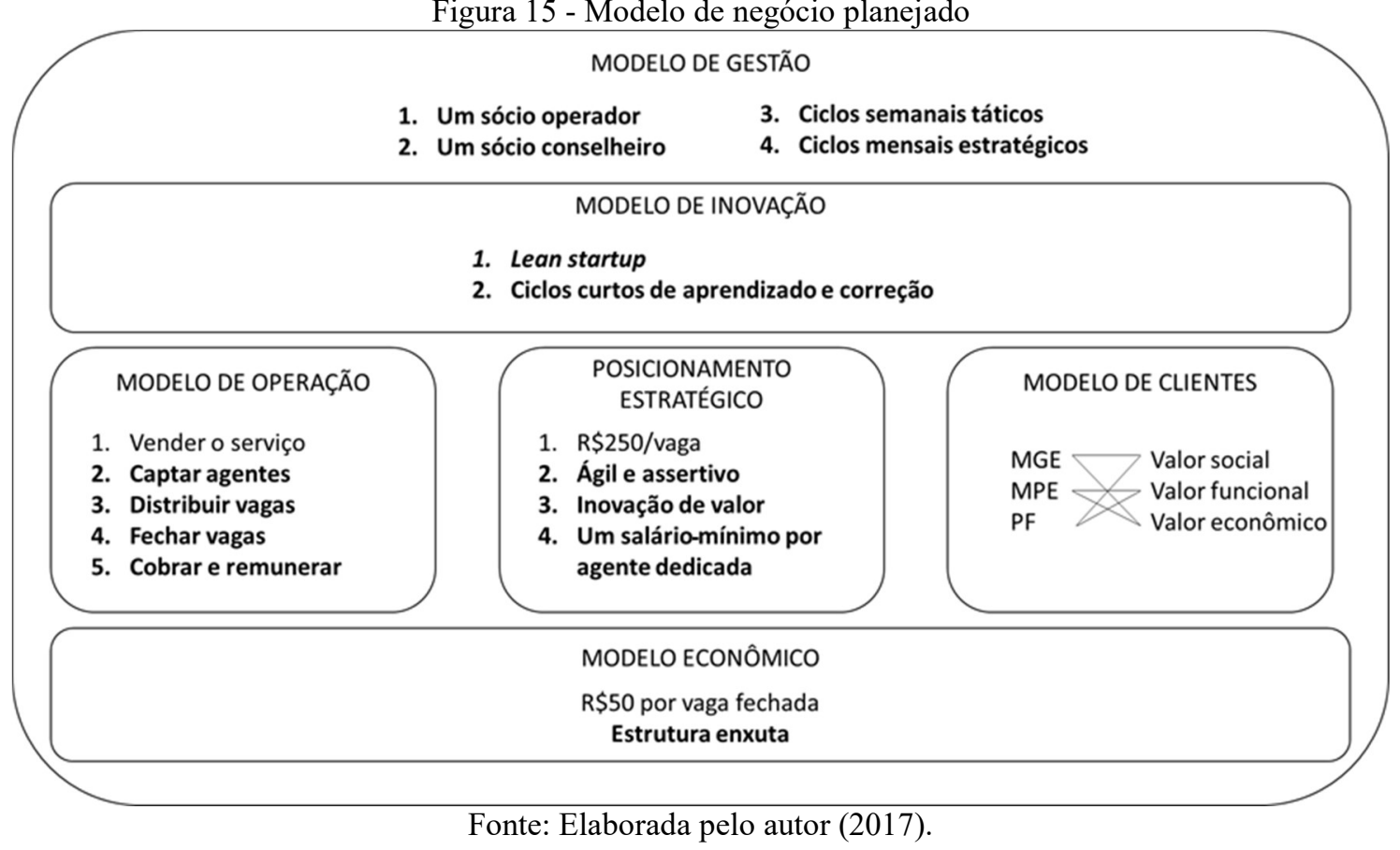

Neste primeiro ciclo, o foco da intervenção estava no modelo de operação, cerne de todo o planejamento executado. O modelo de clientes foi descartado no teste, uma vez que apenas as vagas da ADS foram consideradas. Não houve esforço de venda do serviço, que ainda não possuía uma área no site para anunciar vagas. A esta altura, a ADS já se havia reposicionado como consultoria de recrutamento e seleção de pessoas com deficiência (PCDs). A ADS atuava nesse mercado desde o segundo semestre de 2016, e com o surgimento do projeto da Kunla os sócios entenderem que a empresa tinha mais valor e propósito trabalhando com PCDs do que com vagas operacionais comuns que poderiam ser atendidas pela Kunla.

O trabalho de recrutamento e seleção de PCDs é um trabalho mais meticuloso, definido por detalhes, que envolve não só atrair e selecionar profissionais com certa aptidão profissional mas também conhecer sobre a legislação de cotas e, acima de tudo, incluir no processo seletivo a sensibilidade e o conhecimento sobre vaga, cliente e candidato para assegurar que haja adaptabilidade do profisssional à posição, independentemente da restrição física ou intelectual que este possa ter. A ADS disponibilizou aproximadamente 180 vagas para a Kunla, todos os 
candidatos enviados pelas agentes passariam pela seleção especializada da ADS e depois seriam enviados para os potenciais empregadores.

Uma vez descartada a atividade de vender a solução, a primeira atividade a ser testada foi a de captar agentes. O pensamento sobre o processo a ser testado era bastante simples: captar agentes de recrutamento, passar vagas, receber candidatos e fechar vagas. Para a captação de agentes de recrutamento, a primeira funcionária da Kunla contratada foi Vanda (consultora Kunla), agente social com experiência prévia em visita e cadastro de famílias em comunidades carentes em programas de benefícios sociais do governo. A ideia era aproveitar sua expertise e seu trânsito em comunidades para acessar as famílias, levar a mensagem da oportunidade e empreender através da Kunla. A primeira semana de Vanda foi na ADS, onde aprendeu sobre a atividade de recrutamento e seleção e sobre vagas e profissionais com deficiência. Lá ela foi treinada em como fazer análise de currículos e acompanhou entrevistas.

A meta colocada de produtividade para a consultora Kunla era captar sessenta agentes de recrutamento em três semanas de atividade, uma média de quatro agentes de recrutamento por dia. A estratégia adotada seguiu a prática indicada na literatura de busca de parcerias com lideranças locais para maior produtividade e probabilidade de sucesso (MÁRQUEZ; REFICCO; BERGER, 2010). Ao longo do mês a consultora Kunla visitou as regiões Leste e Norte de São Paulo, sempre buscando entrada através de lideranças locais, e conseguiu captar um total de 43 mães para a plataforma.

Os contatos de todas as mães captadas eram enviados, por WhatsApp, para o celular de da Kunla. O sócio operador, organizador da operação, enviava mensagem de boas-vindas e vagas para cada nova agente de recrutamento captada e aguardava o envio de currículos por parte das novas agentes.

Toda sexta-feira, os sócios conselheiro e operador e Vanda se encontravam para fechar o resultado da semana e programar a atividade de campo da semana seguinte, já considerando os ajustes táticos de falhas identificadas. Ao final do mês, o resultado geral foi apurado e novo planejamento foi definido para o mês seguinte.

A principal preocupação dos sócios envolvidos no dia a dia da operação era a validação da primeira premissa do negócio, a de que havia mães de crianças fora da idade escolar residentes em comunidades e que poderiam estar interessadas em ser agentes de recrutamento. Apesar de o resultado alcançado no mês ter sido inferior ao almejado, o fato de 43 mulheres terem se interessado pela oportunidade foi entendido como validador da premissa e de que a Kunla era capaz de captar essas mulheres para a plataforma. Ao longo do mês a equipe aprendeu 
que o discurso longo e detalhado sobre o modelo da Kunla dificultava a comunicação com as mães. O conceito de negócio inclusivo não era compreendido quando explicado pelo seu conceito: a consultora Kunla teve inúmeros insucessos nesse tema e ela própria demorou todo o mês para compreendê-lo na essência. Ficou evidente que o modelo era complexo e que toda a complexidade deveria ser retirada da comunicação com as agentes. Outro aprendizado foi referente à metodologia de entrada nas comunidades através de lideranças locais ou entidades já atuantes. A Kunla tinha uma urgência e uma velocidade que não era acompanhada pelas entidades e estas acabavam por gerar improdutividade na atividade de captação de agentes de recrutamento. As experiências com lideranças locais tampouco foram produtivas, e houve casos de lideranças almejarem ganhos financeiros pessoais sobre o trabalho das agentes de recrutamento. Os melhores resultados obtidos pela Vanda foram com ações individuais nas comunidades, onde se apresentava em algum comércio ou a um transeunte pedindo indicação de uma família. Mães abordadas indicavam outras, o trabalho dela se ramificava e a visita se tornava mais produtiva ao longo do dia.

Apesar do relativo sucesso na captação de agentes de recrutamento, ao final do mês a quantidade de currículos enviados era irrisória, a qualidade da seleção era muito baixa, incluindo envio de profissionais sem deficiências para vagas exclusivas para esse público. A distribuição das vagas por WhatsApp foi pouco efetiva e considerou-se que o tipo de comunicação, formal e através de textos longos, era inadequada. A mensagem de boas-vindas falava sobre a Kunla, o modelo de negócio e o descritivo das vagas eram demasiadamente extensos e para o próximo ciclo isso deveria ser alterado.

O modelo de operação não foi provado. O primeiro passo, captar agentes, fora bemsucedido, mas a operação parou no estágio seguinte. Sem a validação do modelo de operação, o posicionamento estratégico tampouco foi validado.

Os sócios foram bem-sucedidos na implantação do modelo de gestão e inovação. O sócio operador era responsável por todas as ações da Kunla e era suportado nas tomadas de decisão pelo sócio conselheiro. Os ciclos semanais táticos e os ciclos mensais estratégicos foram efetivamente implantados, embarcando aprendizados e correções rápidas, como no conceito de lean startup (RIES, 2011). A estrutura de custo enxuto foi garantida, a consultora Kunla ficou em campo em tempo integral enquanto o sócio operador trabalhava em home office e às sextas-feiras as reuniões semanais ocorriam em um café. O custo da Kunla estava limitado ao salário da consultora e a encargos, custos bancários, de telefonia e de algumas ferramentas de apoio de tecnologia. 


\subsubsection{Mapa Visual}

Figura 16 - Mapa visual do segundo ciclo

Reflexão: linguagem adotada
na comunicação com as
agentes por WhatsApp era
inadequada (extensa e
formal), o que potencialmente
gerou produção (candidatos
enviados) inexpressiva e de
baixa qualidade.

(1)

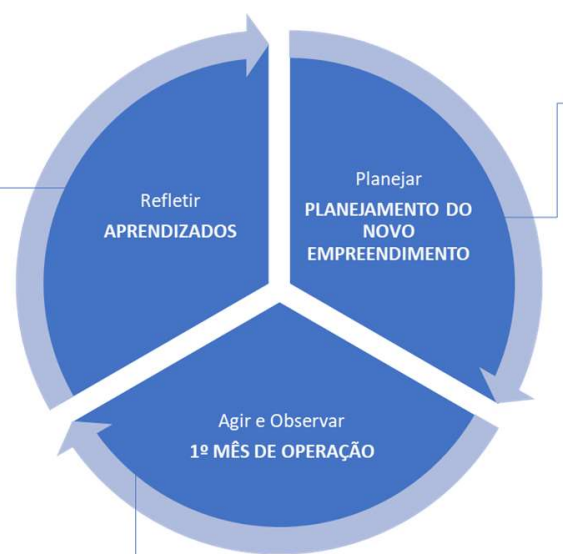

\section{Resultados:}

1. Modelos de gestão e de inovação funcionaram;

2. Apenas uma atividade do modelo de operação funcionou (captar agentes);

3. Negócio adotou a prática de estrutura enxuta.
- Seis dimensões (PEDROSO, 216) planejadas (figura $X X$ ):

1. Modelo de gestão

2. Modelo de inovação

3. Modelo de operação

4. Posicionamento estratégico

5. Modelo de clientes

6. Modelo econômico

- Papel da ADS: provedora de vagas PCD.

- Nova marca desenvolvida.

Fonte: Elaborada pelo autor (2018).

Figura 17 - Itens confirmados no segundo ciclo

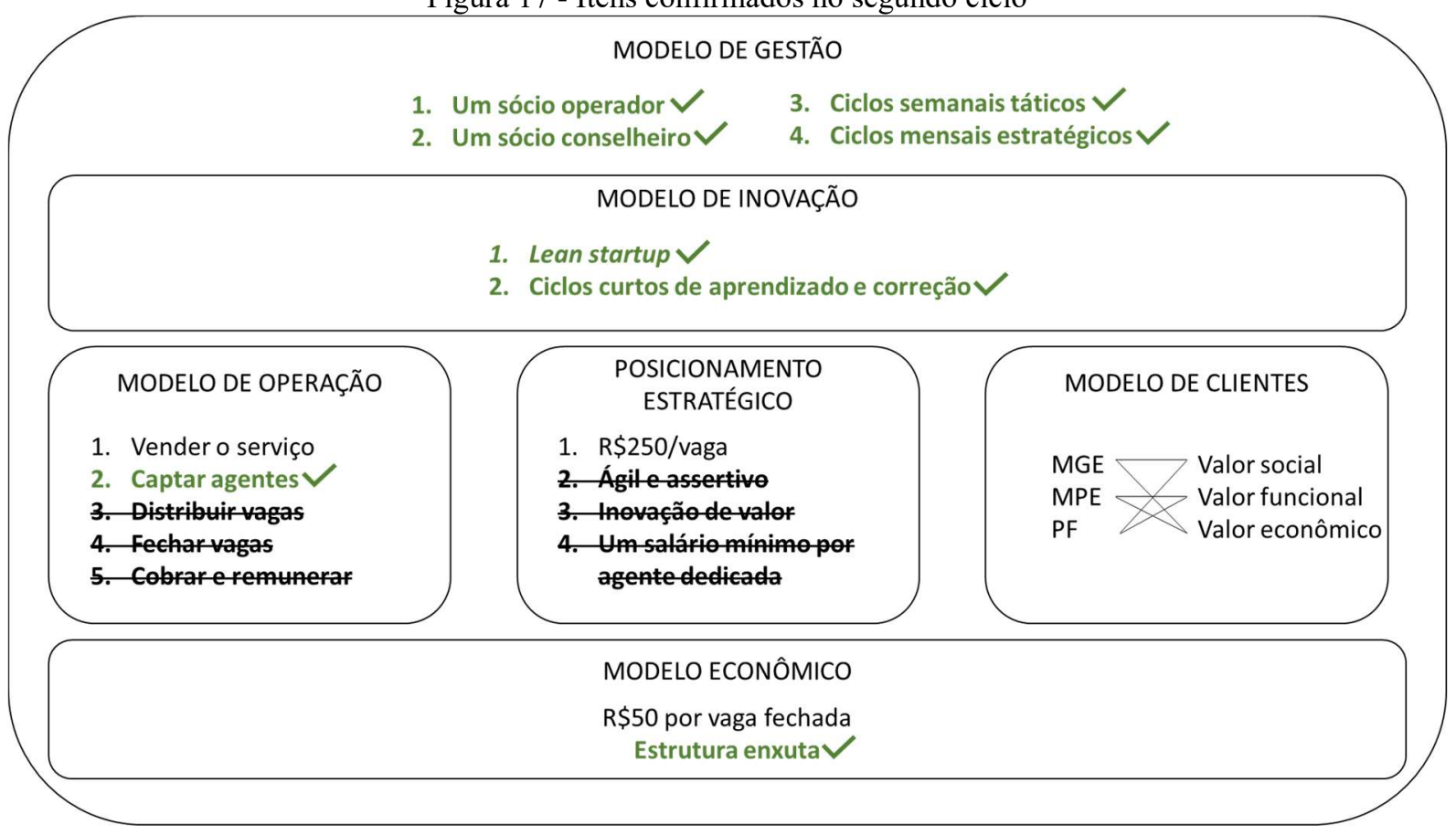

Fonte: Elaborada pelo autor (2017). 


\subsection{Terceiro Ciclo}

\subsubsection{Narrativa}

Os modelos de inovação e gestão, implementados no mês de junho, perduraram durante todo o estudo e a partir do mês de julho as intervenções se focaram na validação do modelo de operação.

O planejamento estratégico da Kunla foi concebido a partir do modelo de operação. A grande inovação do empreendimento, que o caracteriza como um negócio inclusivo, é justamente a inovação no modelo de operação; e, sem a validação deste, todos os demais elementos do planejamento não se sustentam. Por esta razão o estudo focou-se nas intervenções seguintes na busca de um modelo operacional funcional.

Após a finalização do segundo ciclo, concluiu-se que a empresa era capaz de atrair mães em comunidades com filhos sem vagas em creches para a plataforma. A comunicação com essas mães, no entanto, ainda era falha e impedia que o processo evoluísse. O segundo ciclo buscou solucionar esse problema, e para saber se foi solucionado adicionou-se uma nova atividade ao modelo operacional: receber currículos. O primeiro modelo idealizado partia de uma visão simplificada da operação, onde o envio das vagas já culminaria com o fechamento destas na sequência. Entendeu-se, nesse momento, que antes de a vaga ser fechada havia uma etapa de recebimento de currículos que fora omitida mas era relevante, por tratar-se da entrega do serviço das agentes de recrutamento. Ao destacar a entrega do serviço no modelo operacional, seria possível mensurar o sucesso da operação e, ainda mais relevante para essa fase do estudo, a efetividade da atividade anterior de distribuição de vagas. A Figura 18 ilustra os elementos do modelo operacional considerados nessa fase e indica, em negrito, os dois que foram objetos de validação

Figura18 - Modelo operacional de julho de 2017

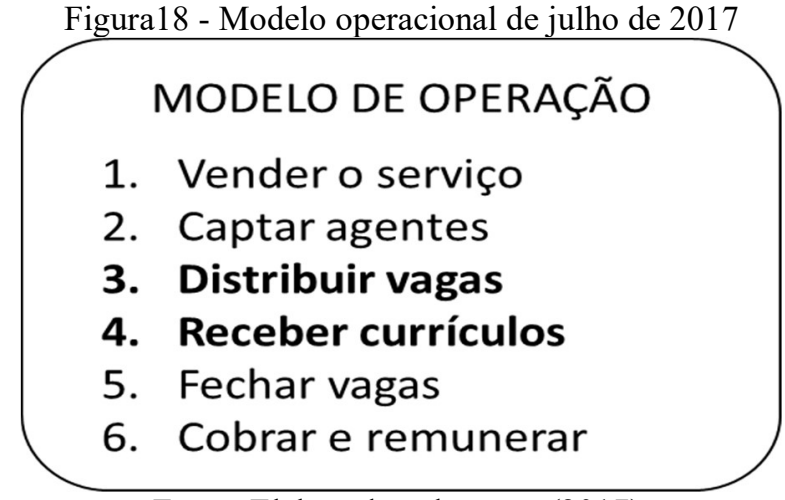

Fonte: Elaborada pelo autor (2017). 
A metodologia de captação de agentes de recrutamento não foi alterada nesse ciclo. A consultora Kunla continuou visitando comunidades sem intermediação de lideranças locais e em função de uma agenda planejada semanalmente durante as reuniões táticas. Ao final do mês a Kunla já tinha agentes de recrutamento em todas as regiões de São Paulo, a produtividade da consultora havia aumentado, seu discurso estava mais simples e orientado e 133 novas mães entraram na plataforma, superando a meta de seis mães por dia.

A distribuição de vagas passou a ser feita por grupos de WhatsApp. O número de agentes de recrutamento aumentara significativamente e não havia mecanismo para a distribuição de vagas individuais. Cinco grupos de WhatsApp foram criados para mães e vagas nas regiões Leste, Oeste, Norte, Sul e Centro. As vagas novas eram enviadas a esses grupos, todas elas da ADS, e as novas agentes recebiam uma mensagem de boas-vindas mais simplificada e depois eram adicionadas aos grupos. O recebimento dos currículos, no entanto, era feito por mensagem individual. O intuito era não só facilitar a distribuição de vagas por região, mas também fomentar uma comunicação em comunidade que pudesse reduzir a distância entre o usuário da Kunla e as mães.

O número de currículos recebidos aumentou consideravelmente: foram 41 currículos recebidos ao longo do mês para as posições anunciadas. A qualidade dos currículos enviados, no entanto, ainda era muito baixa. Continuou a recorrência de envio de currículos de pessoas sem deficiências ou sem aptidão para a função ofertada. $\mathrm{O}$ aumento significativo do número de agentes de recrutamento, que chegou a 176 mulheres no fim do mês, gerou outro problema: uma parcela dessas mães tinha grande dificuldade de compreensão da atividade, principalmente sobre as vagas. Em um grupo tão grande, havia perfis diversos com capacidade de entendimento e aprendizado também diversos, e lamentavelmente notou-se que havia um grupo de mulheres que não estavam aptas à função.

O terceiro ciclo terminou com a mesma frustação do segundo: nenhuma vaga foi fechada. A escala aumentara, a atividade de captação de mães estava em plena produtividade estimada para a consultora, mas o entendimento da atividade, das vagas e dos candidatos era muito baixo. A comunicação constante com as mães mostrou que algumas mulheres entendiam a função e estavam trabalhando adequadamente nela, apesar da ausência de resultados, mas uma grande parcela não conseguia acompanhar o processo.

O aumento da escala de mães recrutadas foi de grande valia para a revelação sobre o problema do perfil traçado para uma agente de recrutamento. Toda semana, quando os sócios e a consultora se reuniam, fazia-se a mensuração do número de mães atraídas para a plataforma 
e a definição da missão da semana seguinte. Os sócios definiam as regiões onde seriam buscadas agentes de recrutamento com base no número de vagas e ARs que possuíam em cada região, e as comunidades eram definidas pela própria consultora. Notou-se que a consultora visitava comunidades com diferentes perfis quanto ao tempo de existência e infraestrutura instalada. As comunidades visitadas variavam de ocupações recentes, com barracos de madeira e nenhuma infraestrutura, a favelas urbanizadas, com água, luz, casas de alvenaria, comércio e serviços. Os perfis dos moradores de cada um desses locais também são bastante distintos e a Kunla se revelou uma ferramenta de trabalho imprópria para os grupos mais vulneráveis, residentes em locais de ocupações recentes e com menos acesso à educação formal. A partir dessa revelação, o perfil da agente de recrutamento foi redefinido para mães de crianças fora da idade escolar, capazes de se comunicar em linguagem escrita e com clareza na comunicação oral, além de residentes e comunidades carentes. 


\subsubsection{Mapa Visual}

Reflexão: algumas agentes se mostraram incapazes de compreender a atividade $\mathrm{e}$ acompanhar os processos (recebimento de vagas e envio de currículos). Levantada a hipótese de que haja um perfil social que não esteja apto para a atividade: mães com menor nível de instrução (incapazes de manter comunicação por linguagem escrita).

Figura 19 - Mapa visual do terceiro ciclo

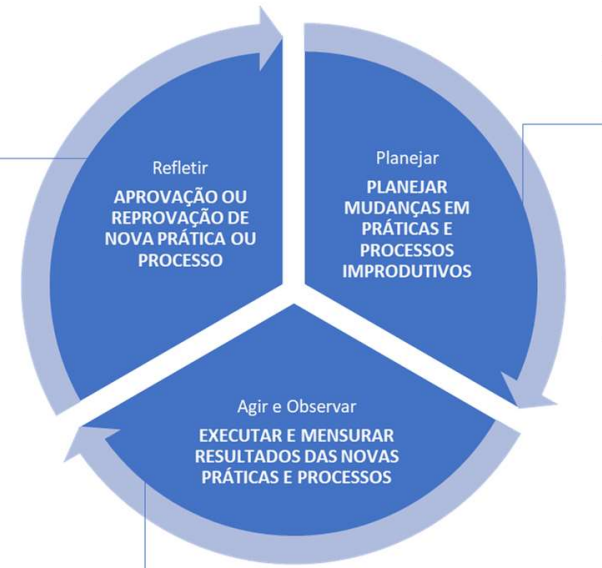

\section{Mudança:}

1. Adaptar a comunicação entre a Kunla e as agentes para uma linguagem mais informal e sucinta;

2. Distribuir vagas através de grupos de agentes no WhatsApp.

\section{Resultados:}

1. Comunicação fluida com algumas agentes, porém totalmente ineficaz com outras.

2. Alguns currículos recebidos, nenhuma vaga fechada.

Fonte: Elaborada pelo autor (2018).

Figura 20 - Item confirmado no terceiro ciclo

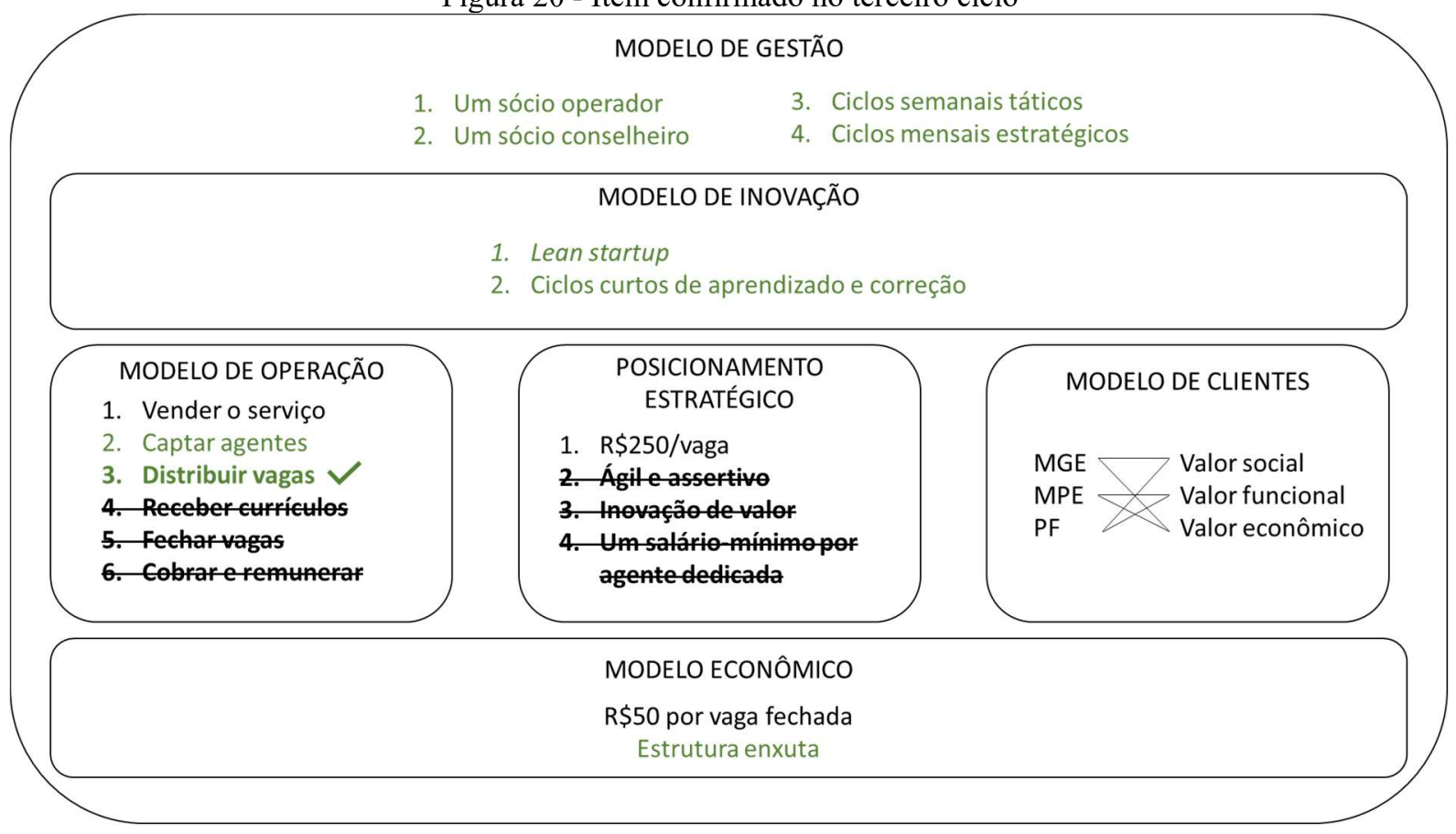

Fonte: Elaborada pelo autor (2018). 


\subsection{Quarto Ciclo}

\subsubsection{Narrativa}

O terceiro ciclo levantou a hipótese de que o insucesso no processo estava limitado não só à mensagem, mas também ao perfil das agentes e de que este precisava ser ajustado. O quarto ciclo objetivou confirmar, ou refutar, essa hipótese e foi chamada de captação qualitativa, em oposição à quantitativa, até então praticada. O objetivo nesse novo ciclo era captar mães mais aptas a trabalhar através de comunicação escrita e com uma média capacidade de comunicação e articulação, fechando assim uma vaga. Os sócios mudaram drasticamente a ambição de fechar vagas que imperou nos dois primeiros ciclos, e assim poder experimentar o ciclo completo.

A captação de ARs, mensurada pela quantidade de mães ingressantes na plataforma, já era considerada bem-sucedida desde o primeiro ciclo, mas a assertividade na seleção dos perfis era baixa. As comunidades visitadas foram revistas, os sócios continuaram definindo as regiões de captação de mães, mas orientaram a consultora sobre a característica das comunidades, locais onde a população teve acesso à educação, e público que deveria ser abordado, pessoas que tiveram um bom entendimento do modelo de negócio da Kunla no momento em que foi apresentado.

A produtividade da consultora, que vinha em movimento ascendente de seis agentes, na primeira semana, para a mais de vinte nas últimas, caiu de imediato com a implantação da nova diretriz. A queda e a posterior estabilização da produtividade evidenciaram que a consultora tinha clareza quanto às diferenças de perfis pessoais, que era capaz de selecioná-los e que isso reduzia sua produtividade na captação de agentes. $\mathrm{O}$ resultado do mês foi assegurado porque a novidade já se havia espalhado, novas mães abordavam a consultora por WhatsApp diariamente, inclusive mães em comunidades nunca visitadas, e assim a consultora não ficou dependente apenas do trabalho de campo para cumprir a meta. Ao final do mês, 140 novas mães faziam parte do grupo de 273 agentes de recrutamento.

A captação mais criteriosa gerou o resultado qualitativo desejado. O sócio operador, que manteve contato direto com todas as agentes, percebeu a melhora na troca de informações e na fluidez da comunicação. Os grupos de WhatsApp, no entanto, mostraram um equívoco. Com o aumento do número de pessoas nos grupos, estes saíram do controle. Assuntos paralelos e de temáticas polêmicas, como política, religião e segurança pública, surgiram e, com eles, desentendimentos e abandonos. Ao final do mês foi concluído que a comunidade de agentes 
não estava pronta para ter um ambiente livre que permitisse a troca de informações e que, no próximo ciclo, os grupos seriam extintos.

Apesar da melhora na comunicação percebida pelo sócio operador, o mês de agosto também não teve uma única vaga fechada. A conclusão era que as mães estavam entendendo o que era a plataforma, a oportunidade e o seu papel, mas não conseguiam de fato selecionar, e às vezes nem mesmo recrutar, os profissionais para as vagas. Era um problema de capacidade de entrega. Concluiu-se que mães em comunidades recrutando e selecionando profissionais para vagas PCD não funcionava. As vagas PCD eram muito complexas, as mães não sabiam reconhecer um profissional para a posição e muitas vezes não sabiam quem abordar. Se funcionasse com essas vagas, funcionaria com todas as outras, mas não funcionou. $\mathrm{O}$ fato de a Kunla não ter funcionado para $\mathrm{PCD}$ não significava que não funcionaria para vagas operacionais convencionais, e essas vagas precisavam ser testadas.

Desde o início da operação a Kunla se apoiou somente nas vagas da ADS, nunca buscou clientes e entendia que só poderia fazê-lo depois que tivesse agentes de recrutamento fechando vagas e com a plataforma pronta. O sócio operador era também o único desenvolvedor técnico da plataforma, e quanto mais a operação fracassava, mais tempo ele dedicava ao dia a dia e ao contato com as ARs, e menos ao desenvolvimento. No final de agosto a Kunla era um fracasso operacional: não havia fechado uma única vaga em três meses e o desenvolvimento da plataforma estava muito atrasado. Diante dessa situação, os sócios tomaram a decisão de seguir adiante mesmo sem a validação do modelo operacional: iriam lançar a plataforma em outubro, trazer centenas de vagas operacionais e distribuí-las às agentes de recrutamento para enfim testarem o modelo com as vagas originalmente idealizadas. 


\subsubsection{Mapa Visual}

Figura 21 - Mapa visual do quarto ciclo

\begin{tabular}{|l|}
\hline Reflexão: apesar de haver um \\
grupo de mães que \\
entendiam a atividade e as \\
vagas, elas se mostravam \\
incapazes de recrutar e \\
selecionar PCDs. Vagas PCD \\
eram muito complexas, as \\
mães não sabiam reconhecer \\
um profissional para a posição \\
e muitas vezes não sabiam \\
quem abordar.
\end{tabular}

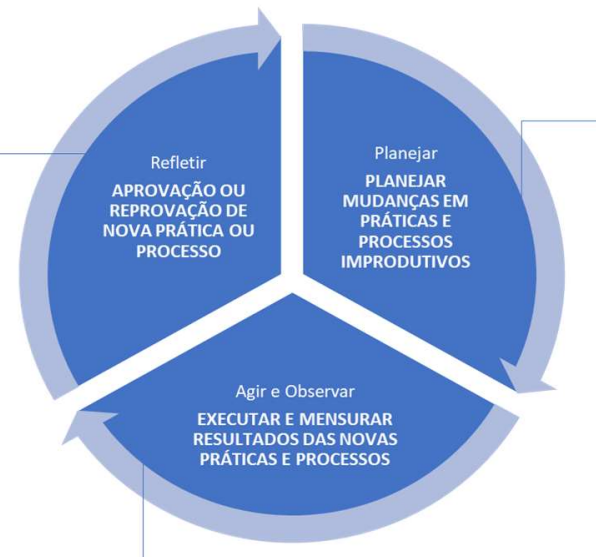

Mudança: alterar o perfil de mães captadas, buscar mulheres mais aptas a trabalhar através de comunicação escrita e com uma média capacidade de comunicação e articulação.

Resultados:

1. Redução do número de mães captadas pela consultora Kunla;

2. Melhora na comunicação e troca de informações com as novas mães;

3. Grupos de WhatsApp perderam o foco e, por essa razão, foram extintos;

4. Poucos currículos recebidos, nenhuma vaga fechada.

Fonte: Elaborada pelo autor (2018).

Figura 22 - Itens provados após quarto ciclo

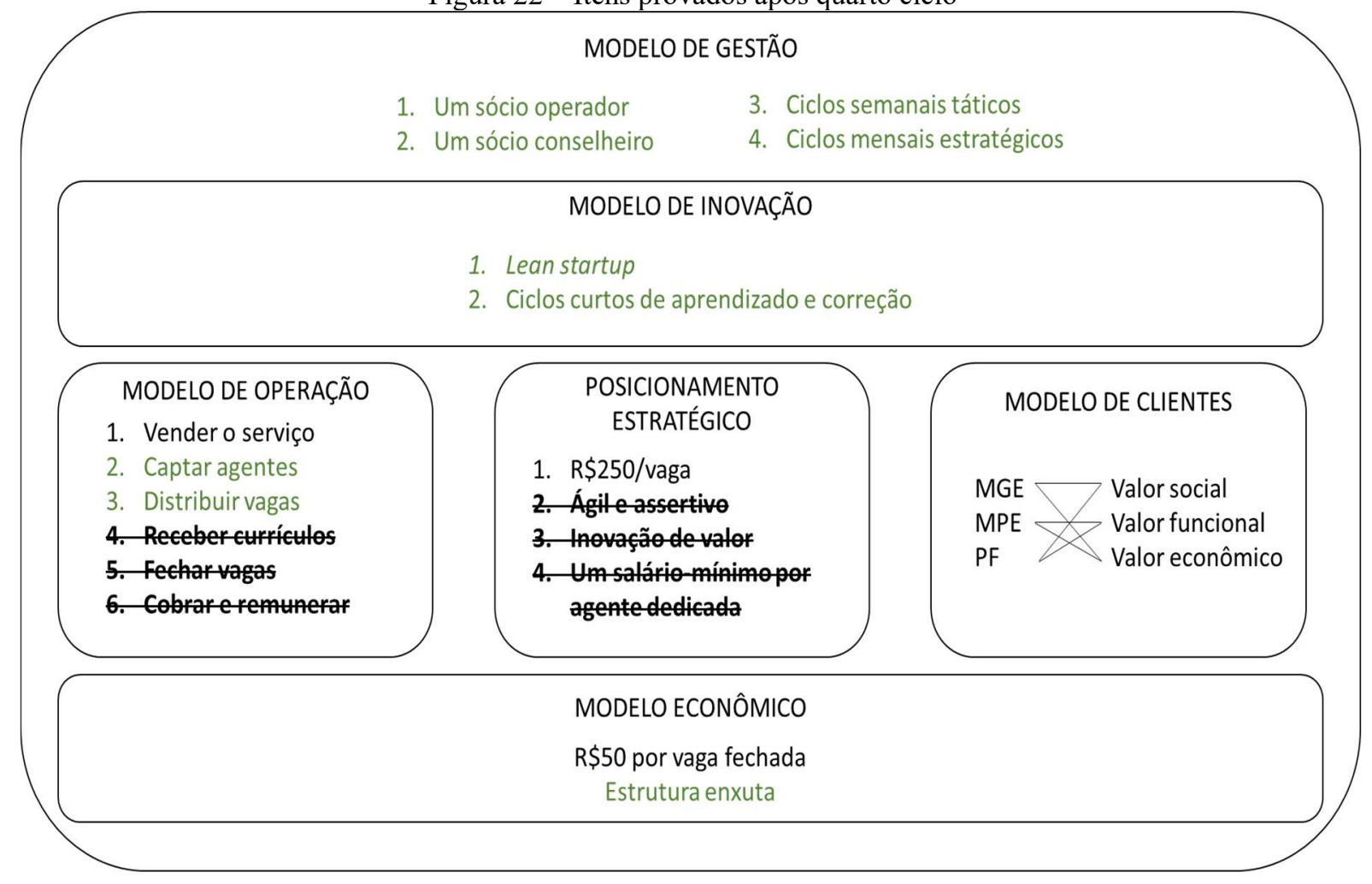

Fonte: Elaborada pelo autor (2018). 


\subsection{Quinto Ciclo}

\subsubsection{Narrativa}

Para o lançamento ocorrer em outubro, os sócios abdicaram de ter o modelo operacional já validado, mas entenderam que a plataforma deveria estar pronta para sustentar o alto volume de vagas anunciadas. Para que a plataforma fosse entregue, o sócio operador deveria atuar em tempo integral no seu desenvolvimento, delegando a comunicação com a base de agentes de recrutamento à consultora.

O grande objetivo desse ciclo era entregar a plataforma e aproveitou-se esse cenário para testar um modelo de comunicação fechada em um único interlocutor. A consultora seria responsável pela captação, distribuição de vagas, orientação e elucidação de dúvidas, recebimento de currículos e envio destes para a ADS. Para facilitar o dia a dia da consultora, foi acordado com a ADS que seriam enviados currículos sem especificação de vagas e a ADS faria a destinação dos candidatos conforme a identificação das habilidades. Esse modelo, simplificado, reduzia o valor da Kunla, que se assemelhava mais a um serviço de recrutamento, sem a seleção.

Todas essas mudanças foram tratadas como temporárias, não havia pretensão de mudar o posicionamento da Kunla, mas era uma oportunidade para compreender se as agentes eram mesmo capazes de recrutar em alto volume, mas não de selecionar.

$\mathrm{O}$ volume de trabalho demandado da consultora aumentou vertiginosamente e o mês começou com duas vagas sendo fechadas, fruto do trabalho de recrutamento e seleção no mês anterior. As duas agentes que obtiveram sucesso mostraram comportamentos bastante distintos: uma enviou doze currículos em dois dias e a maioria deles era divergente daquilo que se buscava para a vaga. Nesse caso, o sucesso veio pela maior probabilidade de acerto ao recrutar um número elevado de candidatos, mas não na precisão da escolha. A segunda foi o oposto: enviou apenas um currículo, meticulosamente selecionado, e obteve sucesso. Ambas foram remuneradas através de ordem de pagamento, um modelo de recebimento que não necessita de conta bancária. O processo foi bem-sucedido e revelou que o custo de cada ordem, primeiramente orçada em $\mathrm{R} \$ 24,00$ por transação, era, de fato, de $\mathrm{R} \$ 30,00$ e que o banco que originalmente faria esse serviço não o tinha mais disponível. O baixo número de vagas fechadas frente ao número de vagas abertas, assim como o alto volume de currículos fora do perfil, fez 
com que os sócios mantivessem o entendimento de que a Kunla não era uma solução adequada para vagas PCDs.

Foi muito gratificante para a equipe ver um sinal de sucesso após três meses de operação, mas nenhuma outra vaga foi fechada ao longo do mês. A comunicação direta com a consultora criou mais empatia e maior proximidade. A comunicação anterior era feita em nome da Kunla (por questão de segurança para a própria mulher, não poderia ser evidenciado que havia um homem por trás do usuário) e seguia uma linguagem mais formal. Vanda se comunicava na forma dela, que era a mesma forma das ARs, com erros de grafia, informalidade e, frequentemente, com mensagens de áudio. Essa aproximação gerou maior envolvimento e, consequentemente, maior volume de mensagens. A consultora ficou sobrecarregada, a atividade de captação em campo declinou, mas o número de novas entrantes se manteve alto pela adesão orgânica (mães que espontaneamente entram em contato). Com o passar das semanas o volume de informações transacionadas por WhatsApp foi tamanho que a consultora perdeu o controle da comunicação com novas agentes e do envio de vagas e currículos.

O quinto ciclo começou com um objetivo claro: ter uma plataforma funcional em um mês e uma ação temporária, centralizar toda a comunicação na consultora. Ao final do ciclo a plataforma não estava pronta: apenas o ambiente de anúncio de vaga. Entendia-se como plataforma a solução tecnológica onde se anuncia uma vaga e esta é automaticamente distribuída para agentes de recrutamento que, em outro momento, também ingressaram na plataforma de maneira autônoma. A plataforma também serve para o envio, pelas ARs, dos candidatos selecionados para as vagas e do informe do profissional contratado pelo anunciante. A experiência com a centralização da comunicação, no entanto, rendeu um bom aprendizado: o engajamento aumenta quando a barreira de comunicação é reduzida.

Desde o princípio da operação os sócios sabiam que eles mesmos não poderiam ser os comunicadores com a base de ARs, mas a prática foi adotada devido ao modelo financeiro de custo enxuto. A experiência de setembro mostrou que havia potencial para criar uma comunicação feminina e informal, com possível troca de ligações e mensagens de áudio, além do primeiro contato na captação. A sobrecarga sobre a consultora resultou em descontrole da operação, mas dentro do caos gerado foi revelado o poder de engajamento da base diante de uma comunicação amigável e igual.

O número de novas agentes saltou para mais de duzentos e a de currículos para mais de 150, números que não podem ser precisados devido ao descontrole dos processos.

Apesar de não terem uma plataforma pronta, assim como não tinham uma operação funcional, os sócios decidiram evoluir com o lançamento do negócio. Entenderam que um 
ambiente para anunciar vagas era suficiente e que toda a retaguarda seria operada por WhatsApp, como se estava fazendo havia quatro meses.

\subsubsection{Mapa Visual}

\section{Reflexões:}

1. Potencial para criar uma comunicação feminina e informal, com possível troca de ligações e mensagens de áudio, além do primeiro contato na captação;

2. ambiente para anunciar vagas era suficiente para lançar a plataforma.
Figura 23 - Mapa visual do quinto ciclo

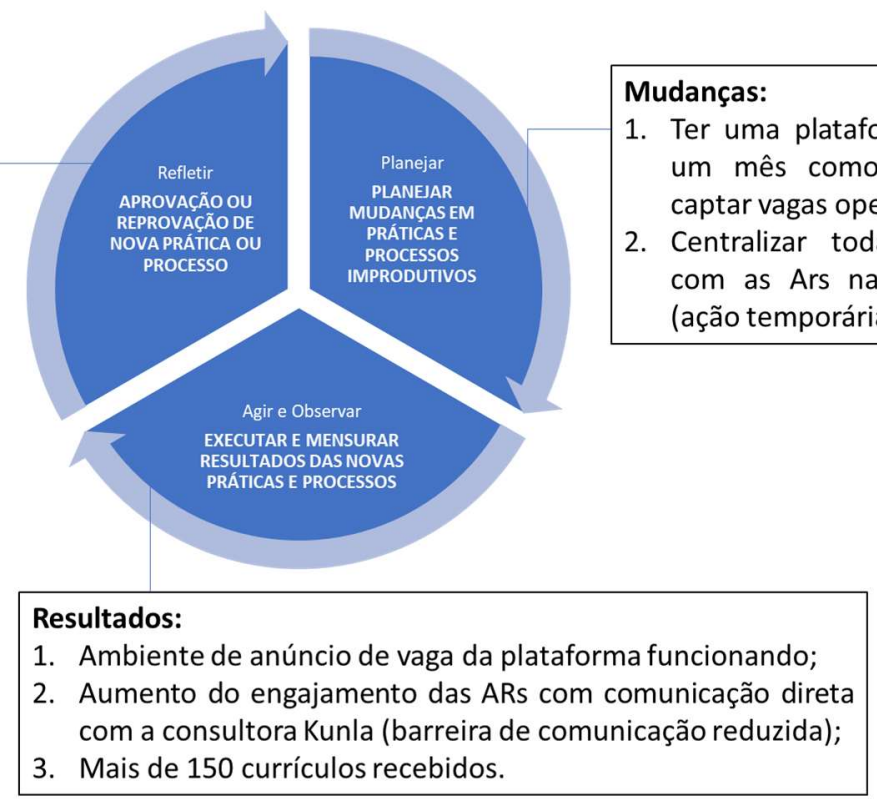

Fonte: Elaborada pelo autor (2018).

Figura 24 - Item aprovado no quinto ciclo

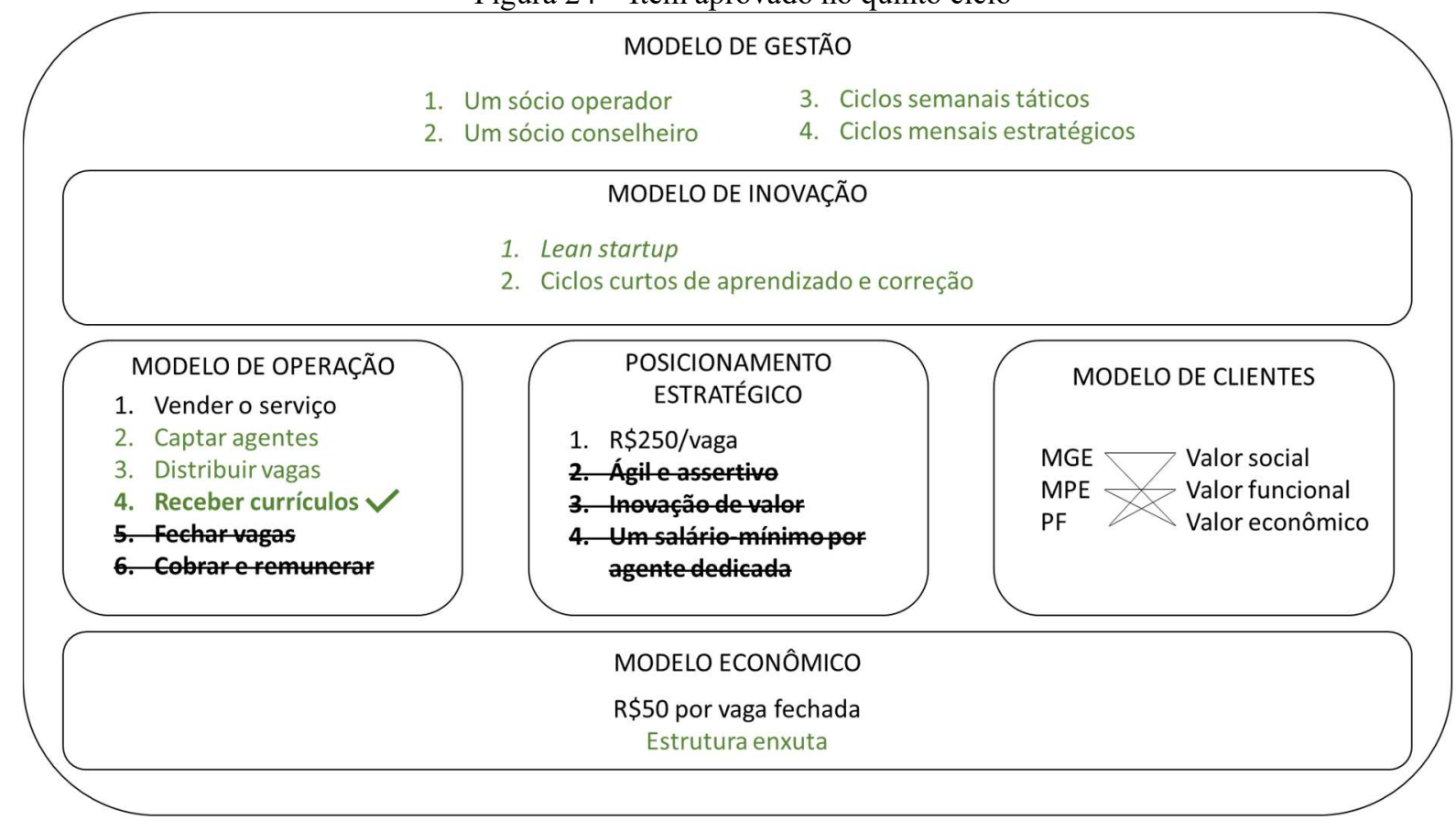

Fonte: Elaborada pelo autor (2018). 


\subsection{Sexto Ciclo}

\subsubsection{Narrativa}

No primeiro dia do mês de outubro de 2017 o ambiente de anúncio de vagas estava no ar e os sócios decidiram apresentar o negócio ao mercado. A única alteração relativamente ao modelo operacional era a possibilidade de crescimento orgânico através de anúncios espontâneos na plataforma. Esse ambiente de anúncio de vaga dava aos sócios a confiança no sentido de que poderiam apresentar o negócio ao mercado sem o constrangimento de não ter um ambiente pronto para tal.

O lançamento da Kunla foi acompanhado de dois esforços simultâneos, um em divulgação em redes sociais e outro em agendamento de reuniões comerciais. Para divulgar a Kunla em redes sociais foi encomendado uma videoanimação que explicasse, de forma clara e emotiva, a proposta de valor do negócio. Os sócios notaram, ao longo dos meses precedentes, que toda vez que apresentavam a Kunla a alguém conseguiam encantar e vender facilmente a ideia. O propósito do vídeo era gerar o mesmo encantamento e convencimento que os sócios conseguiram, podendo assim comunicar em alta escala aquilo que eles faziam dentro de suas limitadas redes de contato. Era, afinal, um vídeo de propósito comercial, que buscava vender a solução pelo valor do modelo de negócios.

O vídeo elaborado, de três minutos, foi muito bem recebido em todos os testes realizados com público amplo. O resultado comercial (anúncios de vagas) obtido com a veiculação do vídeo, no entanto, foi nulo. O vídeo é demasiadamente longo para ser utilizado em redes sociais, onde os melhores resultados são alcançados com vídeos de dez segundos. As visualizações foram muito baixas e o investimento em veiculação foi completamente desperdiçado. Resultados não imaginados foram, no entanto, obtidos com o vídeo, que se tornou material de apoio para comunicação do modelo de negócio da Kunla com potenciais agentes de recrutamento e motivo de orgulho para as atuais agentes, que sentiam ter em mãos um vídeo que contava a sua história. Outro ganho revelado nos meses seguintes foi com o material institucional altamente relevante e útil aplicado a qualquer cenário de exposição do negócio. Concluiu-se, nos meses seguintes, que a qualidade da produção e da mensagem foi recompensadora para o negócio, mas que, naquele formato, isso jamais funcionaria como ferramenta comercial.

Paralelamente ao esforço de captação de vagas por anúncios orgânicos na plataforma, os sócios também começaram a buscar parcerias com grandes empresas. A primeira grande 
empresa abordada foi a Danone, devido ao contato já existente desde a análise do caso do Projeto Kiteiras e do potencial de utilização da Kunla na captação de kiteiras. A primeira reunião comercial da Kunla foi um sucesso e o potencial era enorme. O Projeto Kiteiras, por conceito, não tinha limites de captação de novas kiteiras, uma fórmula extraordinária para a Kunla que passará a ter virtualmente infinitas vagas na região do ABC Paulista (área escolhida para testar o modelo).

A parceria foi estabelecida por intermédio da Danone e firmada com o distribuidor da região. Cada kiteira captada e ativada, ou seja, que comprasse um kit (à vista), seria considerada um sucesso para a agente de recrutamento e esta seria remunerada pelo serviço. A Kunla ainda não possuía agentes de recrutamento no $\mathrm{ABC}$ e, portanto, todo o esforço do mês visando a captação foi orientado para a região. Vanda passou por treinamento no distribuidor para conhecer melhor o programa e pôde acompanhar por um dia o trabalho da melhor kiteira da região. Na sequência ela foi a campo para captar agentes de recrutamento e explicar sobre a Kunla e a atividade, e também sobre o Projeto Kiteiras.

O resultado da captação de agentes de recrutamento seguiu a produtividade já estabelecida, mas elas não se mostraram capazes de captar mulheres em suas comunidades que quisessem empreender como kiteiras. Ao longo das semanas percebeu-se que as múltiplas mensagens entregues por Vanda sobre a Kunla e o Projeto Kiteiras geraram tamanha confusão sobre conceitos que as mães não sabiam nem mesmo se elas próprias eram agentes de recrutamento ou kiteiras. A similaridade e a sinergia entre os negócios, que contribuiu para firmar o acordo de parceria, tornou-se um problema na comunicação com ponta.

A experiência frustrada com o Projeto Kiteiras expôs também a limitação da própria consultora de campo em transmitir múltiplas mensagens, além de organizar informações.

Ao final do ciclo os sócios concluíram que a oportunidade na Danone era enorme: manteriam o foco em busca de uma solução para o caso e já haviam precocemente abandonado a atividade comercial, sendo necessária uma pessoa para ocupar a função de comunicação dentro da Kunla. Praticamente inexistia um trabalho de comunicação externa na Kunla e a comunicação interna (com a ARs) se mostrara falha e improdutiva.

Outra conclusão obtida no quinto ciclo foi a de que a Kunla perdera quatro meses de oportunidades e não precisava de um ambiente de anúncio de vagas para buscar os primeiros clientes, uma vez que esse ambiente não fora utilizado pela Danone.

\subsubsection{Mapa Visual}


Reflexões:

1. Manteriam o foco em busca de uma solução para o Kiteiras (já haviam precocemente abandonado a atividade comercial);

2. Necessário uma pessoa para ocupar a função de comunicação dentro da Kunla;

3. Não precisava ter esperado por um ambiente de anúncio de vagas para buscar os primeiros clientes.
Figura 25 - Mapa visual do sexto ciclo

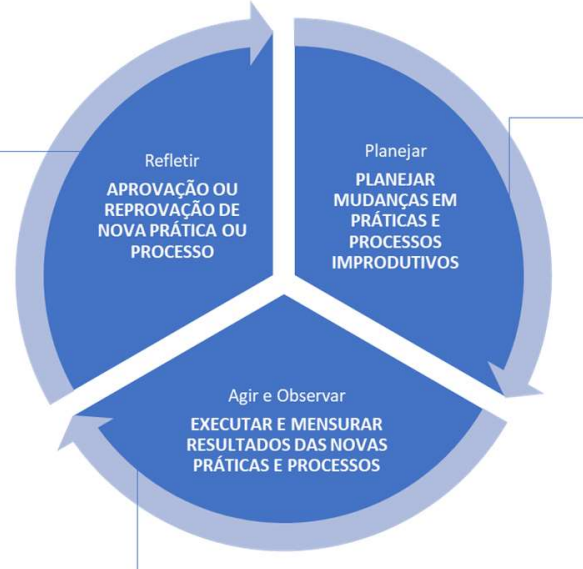

Mudanças:

1. Lançar plataforma;

2. Captar vagas de forma passiva (anúncio com videoanimação)

3. Buscar grandes empresas como clientes.

Resultados:

1. Formato de longo da videoanimação se mostrou ineficaz como ferramenta comercial (nenhuma vaga anunciada);

2. Primeira reunião comercial, com a Danone, foi bem sucedida e a Kunla passou a ser parceira no recrutamento e seleção de kiteiras no ABC;

3. As novas agentes não conseguiram recrutar kiteiras e tiveram dificuldade de entendimento sobre as múltiplas mensagens (Kunla e Projeto Kiteiras).

Fonte: Elaborada pelo autor (2018).

Figura 26 - Itens aprovados após sexto ciclo

\section{MODELO DE GESTÃO}

1. Um sócio operador

3. Ciclos semanais táticos

2. Um sócio conselheiro

4. Ciclos mensais estratégicos

MODELO DE INOVAÇÃO

1. Lean startup

2. Ciclos curtos de aprendizado e correção

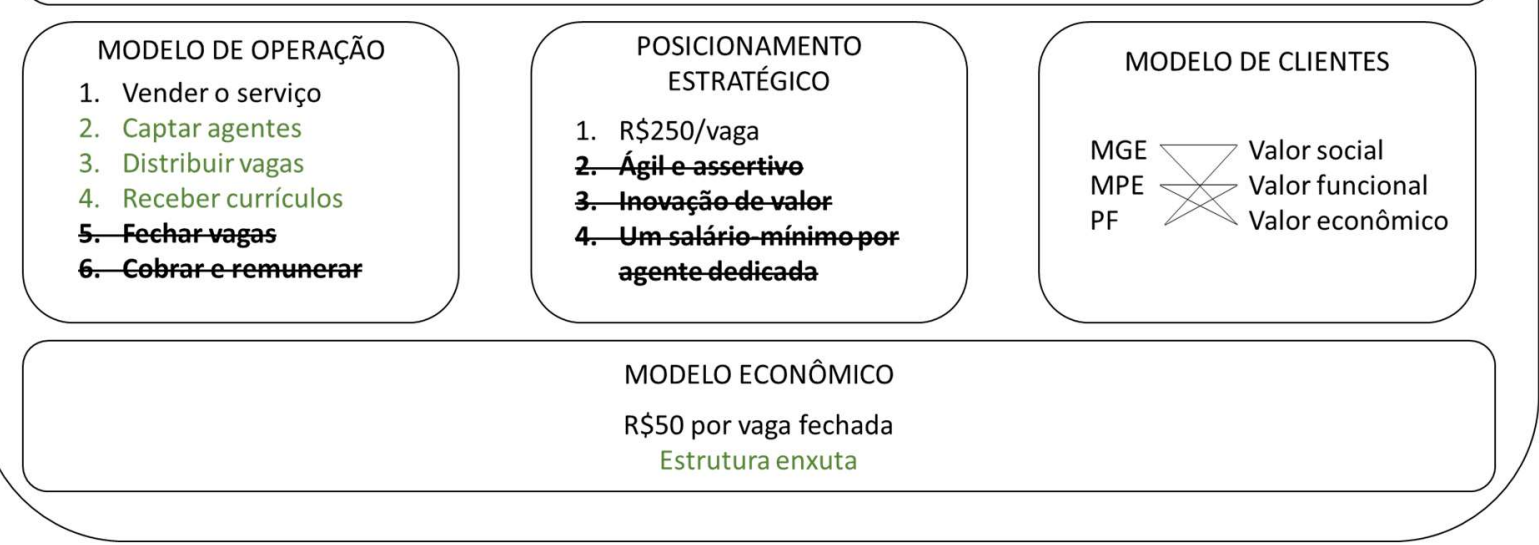

Fonte: Elaborada pelo autor (2018). 


\subsection{Sétimo Ciclo}

\subsubsection{Narrativa}

O sétimo ciclo iniciou-se com a consciência da ineficácia da comunicação interna da Kunla. A Kunla é um negócio que se propõe resolver uma falha de comunicação entre empregadores e empregados mediante um elo comunicador: as agentes de recrutamento. No entanto, a própria Kunla não soube comunicar-se com a sua rede. Era uma falha gravíssima, e os sócios perceberam que a solução que estavam propondo demandaria um trabalho muito mais estruturado e meticuloso do que o que estava sendo executado pela consultora de campo. Dessa forma, a consultora de campo passou a fazer somente o seu trabalho essencial de captar agentes de recrutamento e uma segunda figura foi criada dentro do modelo operacional da Kunla: a assistente de comunicação.

A assistente de comunicação é uma profissional contratada tanto para fazer a comunicação com o mercado (material de comunicação em redes sociais) quanto para organizar a comunicação com as agentes (tirar dúvidas e organizar o fluxo de vagas de candidatos). Para a posição foi contratada uma jovem profisssional residente em comunidade e que trabalhara em um fundo de impacto; ela conhecia a realidade das mães com quem trabalhávamos e acreditava no modelo de negócios inclusivos. Duas semanas após a sua contratação, a comunicação externa já estava novamente negligenciada devido à grande demanda na comunicação interna. Foi criada uma atividade chamada "ativação", onde cada mãe captada pela consultora era contatada por WhatsApp. Explicava-se novamente o modelo de negócio, tiravam-se as dúvidas e só então essa AR era considerada ativada. Com a introdução dessa nova atividade foi constatado que muitas mães entravam na plataforma sem clareza sobre a atividade que exerceriam e que a qualidade da comunicação na ponta ainda estava aquém do almejado.

Figura 26 - Segunda revisão do modelo de operação

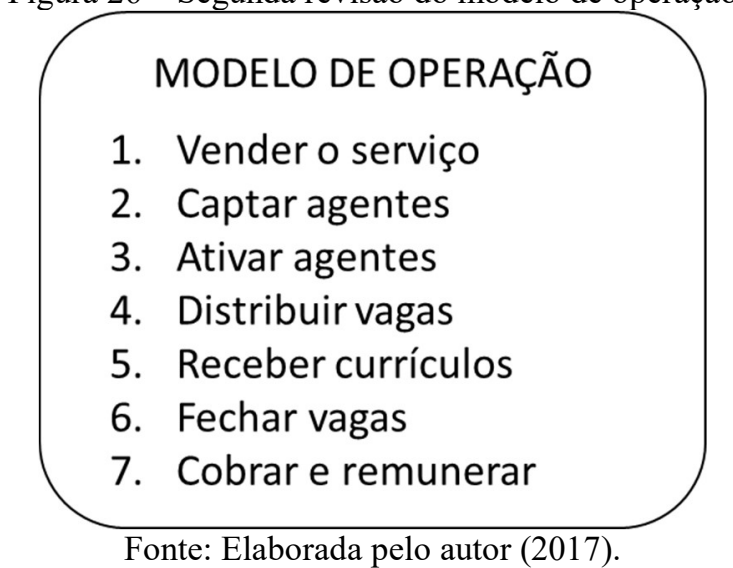


Apesar da melhoria da comunicação interna, a captação de kiteiras continuou malsucedida, assim como o recrutamento de profissionais PCDs para a ADS (que nunca parou de passar vagas). A rede de ARs não estava funcionando e, em adição a isso, a consultora de campo teve afastamento médico na terceira semana do mês. O motivo mais comumente relatado como o impeditivo na captação de kiteiras pelas ARs era a necessidade de R $\$ 150,00$ para a compra do primeiro kit. $\mathrm{O} A B C$ era a região mais crítica do Projeto Kiteiras, não se conseguia avançar e as ARs não estavam tendo melhor sorte.

Após dois meses focados no Projeto Kiteiras, o resultado da Kunla continuava nulo, e agora sem a consultora de campo. O modelo não conseguia se provar, mas os sócios entendiam que ainda precisavam testar a Kunla com vagas operacionais convencionais, que não fossem exclusivas para profissionais com deficiência e que não fossem oportunidades de trabalho autônomo que demandasse investimento inicial do captado. Era preciso vender o serviço. Para isso, decidiram montar a primeira equipe de vendas do serviço com três vendedores e as vagas foram distribuídas entre as ARs. Uma nova vaga de consultora de campo também foi distribuída entre as ARs: a Kunla estava usando a Kunla para suas vagas.

O sucesso que a Kunla não alcançava com seu modelo de negócios, alcançava-o com a mídia. Mesmo sem fazer qualquer esforço de relações públicas, veículos de comunicação de agentes do ecossistema de negócios inclusivos começaram a buscar a Kunla. Na primeira quinzena de novembro uma grande reportagem foi veiculada no Projeto Draft (Anexo B) e na segunda metade do mês a aceleradora Artemísia entrou em contato com a Kunla com o fim de convidá-la para o processo de seleção para aceleração do programa Estação Hack, uma parceria entre Facebook e Artemísia. Ao final do mês, o negócio que lutava para provar seu modelo de negócio estava entre os aprovados para a primeira turma da Estação Hack e ainda ostentava o status de único negócio legitimamente social dentre os aprovados (os demais eram negócios com algum impacto social). 


\subsubsection{Mapa Visual}

Figura 28 - Mapa visual do sétimo ciclo

\section{Reflexões:}

1. Precisavam testar a Kunla com vagas operacionais convencionais, que não fossem exclusivas para profissionais com deficiência e que não fossem oportunidades de trabalho autônomo que demandasse investimento inicial do captado;

2. Era preciso vender o serviço.

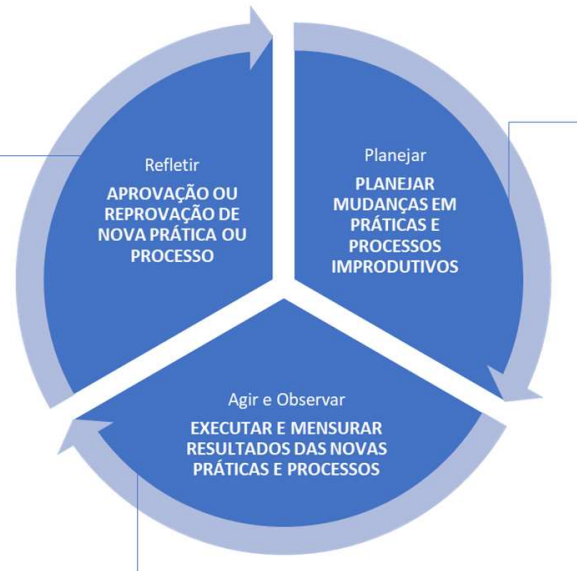

Mudanças:

1. Alocação de uma profissional dedicada à comunicação com as agentes;

2. Adoção da atividade de "ativação" das agentes.

\section{Resultados:}

1. Constatado que muitas mães entravam na plataforma sem clareza sobre a atividade que exerceriam;

2. Apesar da melhoria da comunicação interna, a captação de kiteiras continuou malsucedida (necessidade de investimento inicial de $R \$ 150,00$ era barreira), assim como o recrutamento de profissionais PCDs para a ADS.

Fonte: Elaborada pelo autor (2018).

Figura 29 - Novo item adotado após sétimo ciclo

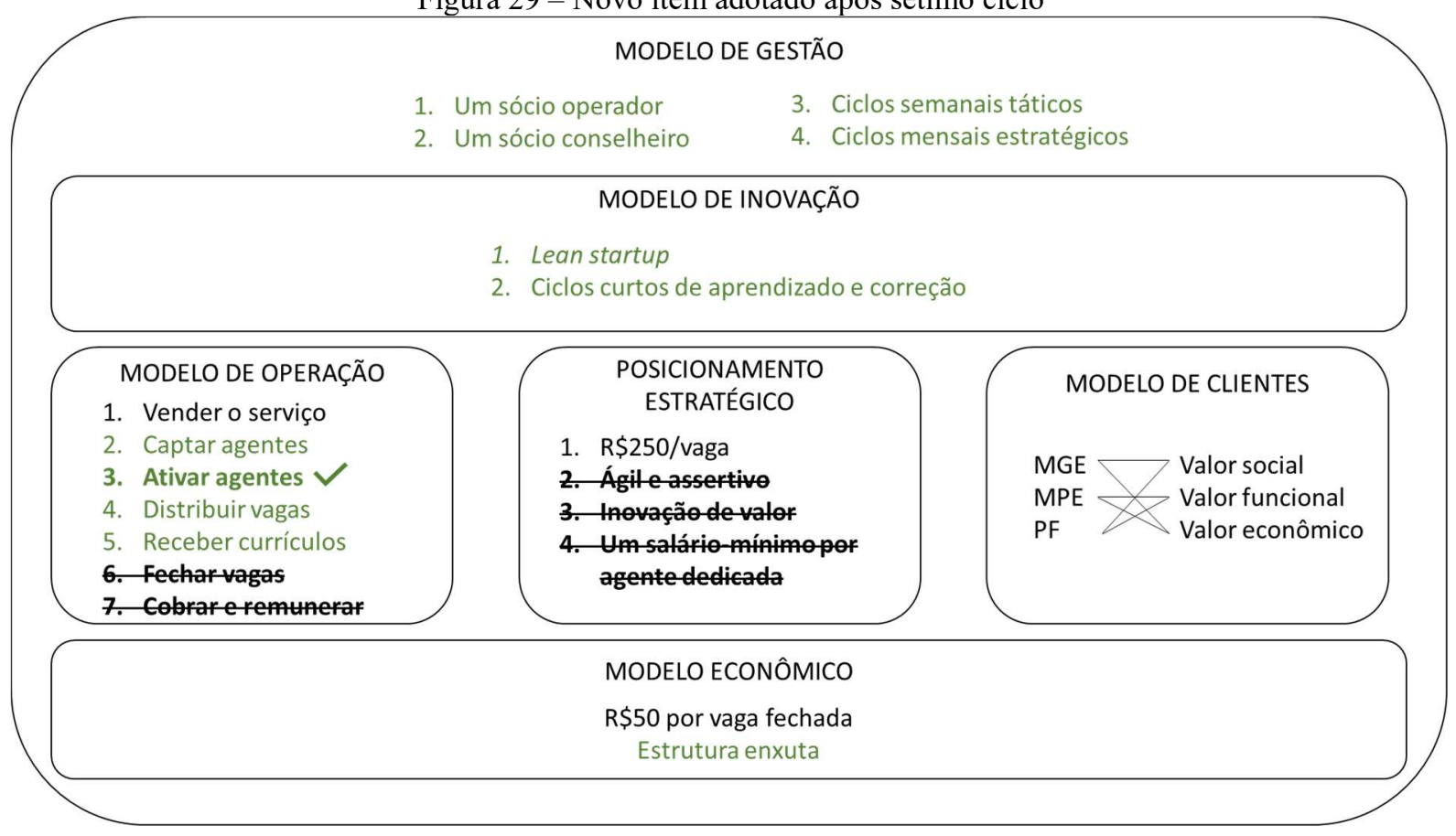

Fonte: Elaborada pelo autor (2018). 


\subsection{Oitavo Ciclo}

\subsubsection{Narrativa}

O mês de dezembro começou com a apuração dos serviços das ARs entregues à Kunla. Os candidatos para as posições de vendedores e de consultora de campo foram recebidos e a conclusão foi clara: elas não estavam fazendo seleção. A assistente de comunicação fez o trabalho de selecionar os currículos recebidos e fazer a primeira entrevista de avaliação; antes dos sócios, os currículos pareciam ter sido enviados sem critério. Ao final, a consultora de campo foi contratada por indicação de uma $\mathrm{AR}$, mas nenhum candidato pôde ser aproveitado para as vagas de vendas.

A constatação de que as ARs não conseguiam fazer o trabalho de seleção foi um divisor de águas. Até o momento, a Kunla considerava que uma AR era capaz de selecionar candidatos para vagas operacionais e nada fizera para agir sobre a questão. A primeira ação foi mudar a nomenclatura: agentes de recrutamento ou ARs nunca mais foram utilizadas e o termo oficial passou a ser Agente de Recrutamento e Seleção ou, de forma reduzida, somente Agente. A segunda ação foi definir a jornada de formação de uma agente, que passou a integrar o cerne do modelo operacional da Kunla. Toda agente percorreria o processo de captação, ativação e formação, que seria dividido em três módulos: recrutamento, seleção e acompanhamento do processo.

$\mathrm{Na}$ etapa de captação a mãe seria exposta à oportunidade apresentada pela consultora, de forma presencial e dentro da comunidade. Na ativação seria detalhado o modelo de negócio, seriam tiradas as dúvidas e, uma vez ciente e confirmado o interesse em fazer parte da rede de agentes, a mãe passaria a ser chamada de agente. A primeira vaga lhe seria disponibilizada para que ela pudesse trabalhar, e invariavelmente o primeiro resultado não seria positivo. Nesse momento lhe seria oferecida a oportunidade de passar para capacitação e, se aceitasse, ela entraria no programa de aprendizado, que envolveria uma primeira capacitação na atividade recrutamento (técnicas e melhores práticas), seguido pelo de seleção e, por último, pela atividade de acompanhamento de candidatos em processo. A sequência foi idealizada a partir do fluxo de um processo de onde se recrutam candidatos, selecionando-se entre eles os que estão aptos para a função e depois acompanhando o processo (datas de entrevistas, documentação etc.). 
Figura 30 - Terceira revisão do modelo de operação

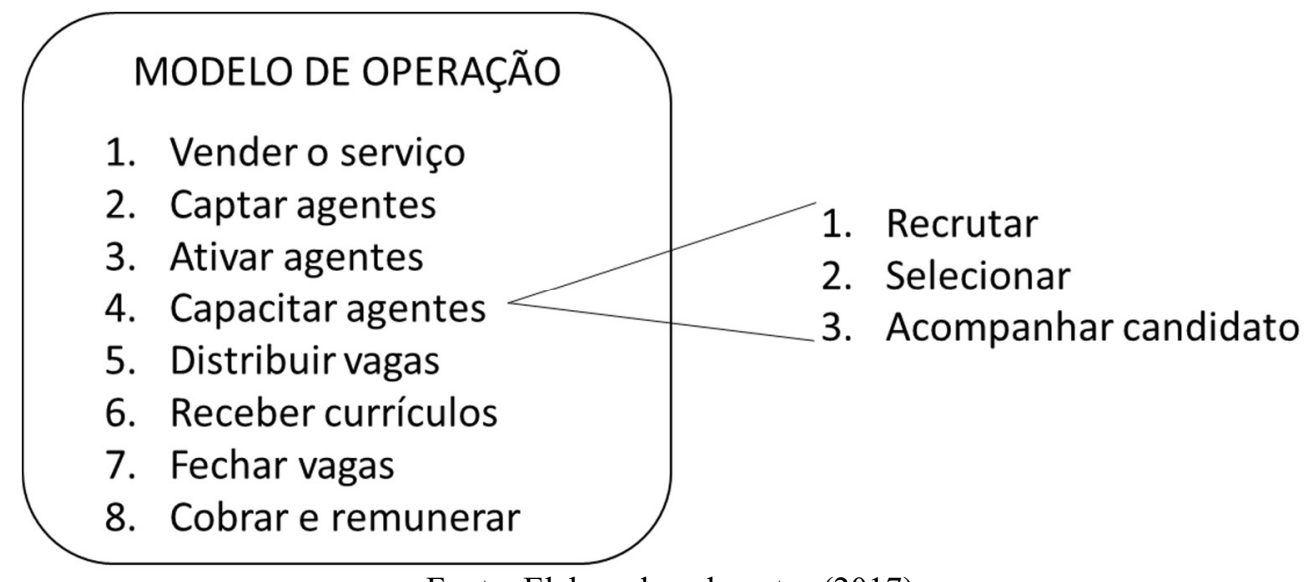

Fonte: Elaborada pelo autor (2017).

A capacitação foi idealizada para ser feita em formato de palestras ministradas pelas próprias agentes mais experimentadas e eficientes em cada tema. As primeiras turmas foram planejadas para janeiro e uma agente de Carapicuíba, com o melhor histórico de envio de currículos, seria quem faria a primeira capacitação, sendo remunerada por isso.

A terceira ação empreendida para corrigir a incapacidade das agentes de selecionar foi, mais uma vez, na comunicação. A Kunla seguia um vício, herdado da ADS, de informar as vagas às agentes no mesmo formato que se divulga uma vaga a um candidato. Uma vaga é divulgada a um candidato com os pré-requisitos para a função, mas o empregador passa à consultoria de R\&S informações adicionais sobre o profissional almejado que são omitidas no anúncio. São informações sutis, como personalidade e postura, que orientam o selecionador em seu trabalho. Ao se comunicar com as agentes como se comunica com candidatos, a Kunla estava comprometendo a capacidade das agentes de realizar seleção.

No oitavo ciclo foi testada a equipe dedicada a vendas. As agentes falharam na entrega dos candidatos, mas a ADS colaborou com a apresentação de seis profissionais, dos quais três foram selecionados. Uma das candidatas desistiu antes de começar na função e a posição não foi reposta porque se aproximava o Natal e não havia perspectivas de muito sucesso comercial nas próximas semanas. Das duas vendedores que iniciaram, uma abandonou o emprego no segundo dia e a outra saiu de licença médica após uma semana e não retornou mais. O plano de montar uma primeira estrutura comercial foi um fracasso relâmpago.

A nova consultora de campo, uma atriz e assistente social recrutada por uma agente, iniciou-se na função e seus primeiros esforços foram através da articulação com ONGs e lideranças locais. Dessa vez, no entanto, os resultados foram muito positivos e ela obteve, já na primeira semana, uma produtividade equivalente à da consultora já experiente. A diferença 
percebida pelos gestores estava em sua capacidade de articular e, principalmente, na rede de contatos que já detinha. A nova consultora, no entanto, permaneceu apenas duas semanas na atividade e também saiu de licença médica.

Nas duas últimas semanas de dezembro a Kunla possuía quatro funcionários e três deles estavam afastados por licença médica. Faltava quem vendesse o serviço e quem captasse agentes; a operação estava parada. O mês só não foi perdido porque se iniciou com o aprendizado sobre a necessidade de capacitação e o consequente ajuste no modelo operacional.

\subsubsection{Mapa Visual}

Figura 31 - Mapa visual do oitavo ciclo

\begin{tabular}{|l|}
\hline Reflexões: \\
1. Era preciso capacitar as \\
mães nas atividades de \\
recrutar e selecionar; \\
2. Não adiantava vender o \\
serviço antes de ter mães \\
capazes de entregá-lo.
\end{tabular}

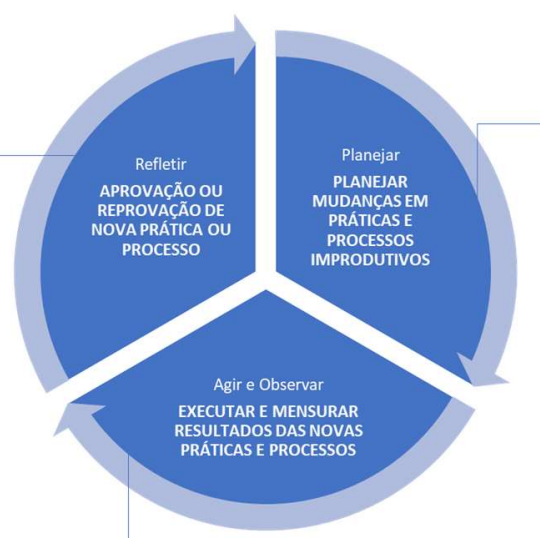

Mudança: estruturar equipe de vendas e vender o serviço.

Resultados:

1. Nova estrutura de vendas não durou mais que uma semana;

2. Kunla, ao usar o serviço das agentes para suas próprias vagas, descobriu que havia grande debilidade na atividade de seleção dos candidatos por parte das agentes.

Fonte: Elaborada pelo autor (2018).

Figura 32 - Novo item adotado após oitavo ciclo

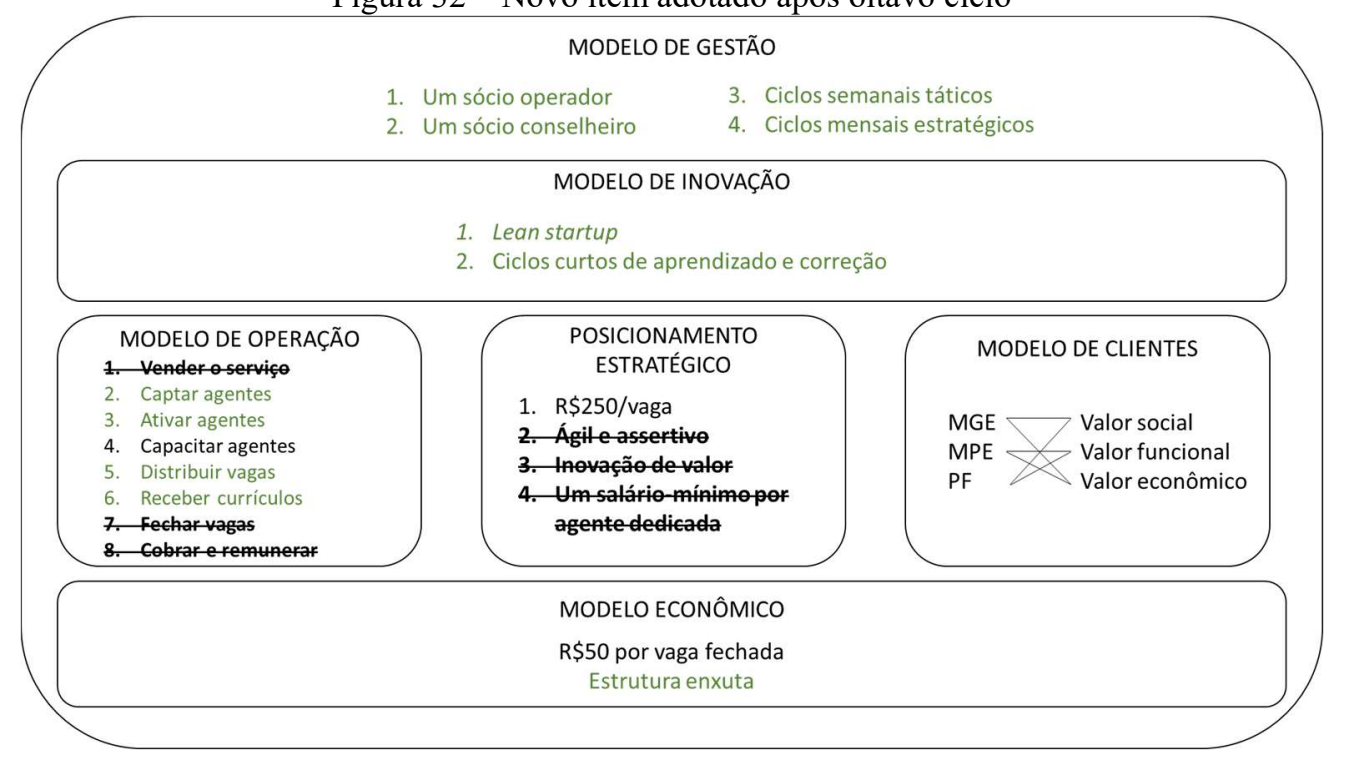

Fonte: Elaborada pelo autor (2018). 


\subsection{Nono Ciclo}

\subsubsection{Narrativa}

Janeiro de 2018 iniciou com novo aporte financeiro dos sócios, como planejado. O aporte veio na sequência de um ciclo bastante negativo em dezembro de 2017 e de um resultado operacional acumulado nulo. A combinação de insucesso nos últimos sete meses, o colapso da operação em dezembro e a necessidade de novo aporte fez do oitavo ciclo o mais tenso vivido pelos sócios até então. Para aumentar a tensão e a incredulidade em relação aos acontecimentos com a equipe, a primeira semana do mês contou com o retorno da consultora de campo recémcontratada às atividades, acompanhado do afastamento por licença médica, por uma semana, da assistente de comunicação. A Kunla teve, naquele momento, cem por cento de seus funcionários afastados por licença médica num horizonte de um mês. $\mathrm{O}$ retorno da consultora de campo devolveu uma sadia capacidade de captação de agentes, cerca de vinte mães diariamente.

Janeiro foi o primeiro mês da Kunla dentro do programa de aceleração do Facebook e da Artemísia, a equipe passou a ter um local de trabalho fixo sem custo.

A intervenção desenhada para o nono ciclo foi a implantação do método de capacitação das agentes por meio de palestras ministradas pelas agentes mais experientes. Ao longo de três semanas foi planejado, e sem sucesso tentou-se implementar o modelo. A primeira agente escolhida e orientada para a atividade desistiu na véspera da primeira palestra. De forma bastante legítima, ela alegou dificuldade de locomoção e indisponibilidade de tempo para honrar o compromisso em uma comunidade distante da sua.

O insucesso na intervenção planejada foi seguido por um aprendizado nascido em meio a fracassos sucessivos. A Rede Globo entrou em contato com a Kunla porque gostaria de fazer uma reportagem sobre o negócio para ser veiculado no programa "Como Será?", de Sandra Annenberg. A reportagem, de aproximadamente dez minutos, almejava contar a história do negócio, dos sócios, da atividade de campo da consultora, das agentes, dos candidatos e dos empregadores. Os sócios foram entrevistados e fizeram-se filmagens em campo ao longo de um dia, mas para fechar a matéria era preciso ter vagas fechadas para que a história da agente, do candidato e do empregador da vaga fechada fosse contada. A ADS, por pertencer aos mesmos sócios, e, também, não ser o empregador, foi descartada, e assim não havia história a ser contada. Uma reportagem completa sobre o negócio daria à Kunla uma visibilidade que os 
sócios não gostariam de desperdiçar. Em meio à tensão do mês, das decepções com os recorrentes insucessos e da oportunidade próxima a ser perdida, os sócios tiveram a ideia de pedir ajuda a um amigo proprietário de uma casa de chá para que contratasse alguém pela Kunla a fim de fechar a pauta. O serviço seria gratuito e a Kunla remuneraria a agente que fechasse a vaga. A ideia foi aceita, a vaga foi aberta, candidatos foram enviados, um foi contratado e a agente foi remunerada. A contratação, infelizmente, ocorreu após o prazo-limite acordado com a equipe da reportagem. A experiência, motivada por um momento de desespero dos sócios, lançou luz sobre uma nova prática a ser testada no próximo ciclo: ofertas de serviço gratuito a empregadores como forma de experimentação. A lógica era simples, a equipe de vendas que se objetivava montar em dezembro tinha custo equivalente a quarenta vagas gratuitas (vagas nas quais se remunera a agente, mas não se cobra o empregador), e parecia mais produtivo dar quarenta vagas mensalmente, fazer a operação girar e ainda ter a chance de recorrência de postagem por empregadores que tiveram uma boa experiência. O valor deixaria de ser investido em funcionários e seria redirecionado para agentes. Isso parecia também mais apropriado àquilo em que a empresa acreditava.

O insucesso da intervenção em janeiro foi entendido como um insucesso do método idealizado para a execução da capacitação e não da capacitação em si. A capacitação, de fato, não foi realizada, e portanto não se pode identificar o resultado gerado pela sua execução. $O$ próximo ciclo deveria buscar novas formas de fazê-lo e, ainda, implantar o novo aprendizado do nono ciclo. Seriam duas intervenções paralelas, na forma de vender e na forma de entregar. 


\subsubsection{Mapa Visual}

\section{Reflexões:}

1. Uma mãe com filho fora de creche não pode trabalhar fora de casa, portanto não pode dar palestras a outras agentes em outras comunidades. Necessário testar novo processo de capacitação;

2. Parece ser mais produtivo dar quarenta vagas (não cobrar e, mesmo assim, remunerar a agente) que gastar o mesmo valor em equipe de vendas cujo resultadoé imprevisível.

Figura 33 - Mapa visual do nono ciclo

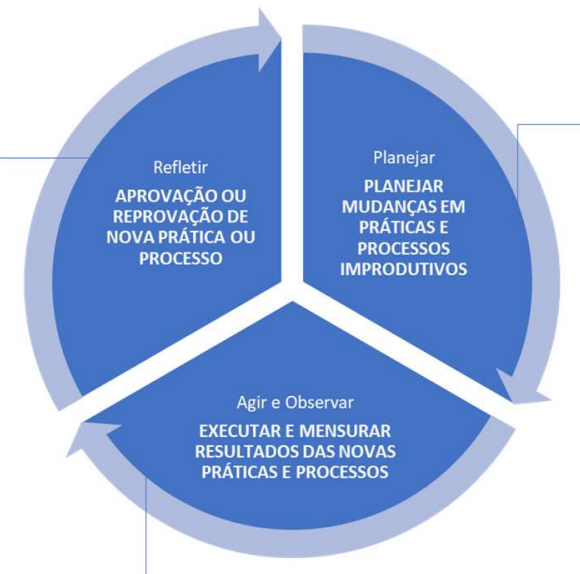

Mudanças: planejar e implantar a atividade de capacitação das agentes.

Resultados:

1. Capacitação de agentes por agente não funcionou;

2. Um cliente testou o serviço de forma gratuita e contratou um profissional para uma vaga operacional.

Fonte: Elaborada pelo autor (2018).

Figura 34 - Itens provados após nono ciclo

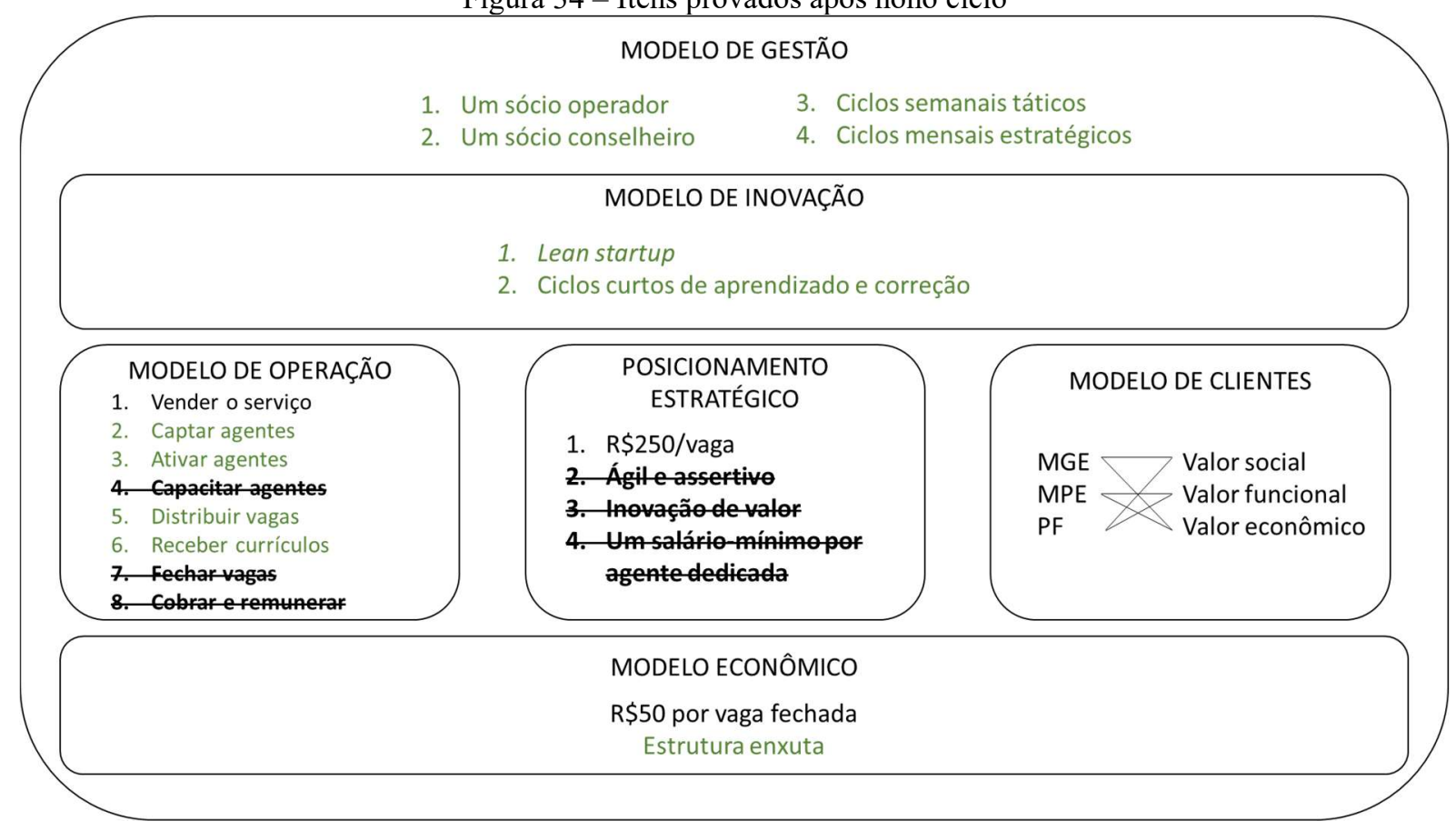

Fonte: Elaborada pelo autor (2018). 


\subsection{Décimo Ciclo}

\subsubsection{Narrativa}

Os sócios, na atividade de empreender, devem enfrentar grandes fracassos com frieza e racionalidade e, comumente, pequenos sucessos são comemorados com emoção e entusiasmo. O mês de fevereiro começou com bastante entusiasmo: o fechamento de uma vaga, seguida de elogio sobre serviço prestado pelo empregador, apontou novamente para a viabilidade do modelo. O mês tinha duas intervenções a serem realizadas: mudar o modelo comercial para a distribuição de vagas de experimentação e testar nova forma de capacitação.

A Kunla possuía capacidade de geração de oferta do serviço muito superior à de geração de demanda por ele. A produtividade de captação de agentes era alta e estável, ao mesmo tempo que não havia competência para a venda do serviço. Para reduzir o descompasso entre oferta e demanda, e sem criar novo custo de pessoal para a empresa, a consultora de campo passou a ter uma atividade extra em sua rotina, qual seja, a de ofertar o serviço no comércio. O trabalho de captação da consultora estava sendo desperdiçado pela ausência de vagas, e portanto não era necessário que continuasse captando uma centena de mães semanalmente. Seu trabalho de captação de agentes foi reduzido para três dias semanais, os primeiros três dias da semana, e os dois últimos passaram a ser dedicados à oferta do serviço porta-a-porta. A rotina da consultora passou a ser visitar três comunidades em uma mesma região nas segundas, terças e quartasfeiras e visitar o comércio próximo a essas comunidades nas quintas e sextas-feiras. Nessa rotina, as mães que eram captadas no início da semana passavam por ativação e na sequência recebiam as vagas novas. O modelo foi bem-sucedido, a produtividade estável da consultora na captação de agentes assegurava a entrada de sessenta novas mães na plataforma toda semana e ainda a abertura de dez a vinte vagas próximas a elas.

Paralelamente à oferta gratuita do serviço, um novo modelo de capacitação a distância foi testado. À assistente de comunicação se juntaram duas novas funcionárias que dividiram a base de agentes ativas e cada qual ficou responsável por toda a comunicação e capacitação das agentes sob seus cuidados. A instrução, por telefone, sobre as melhores práticas de recrutamento e sobre como selecionar (já usando como caso ilustrativo as vagas que a agente possuía para trabalhar) teve um resultado surpreendente. A Kunla descobriu que capacitar essas mães era mais fácil do que imaginava, podendo ser feito por telefone, e que os resultados eram satisfatórios. A equipe, que também recebia os currículos antes de os enviar aos clientes, notou que a assertividade havia subido abruptamente. Os currículos chegavam rápido, eram bons e 
bastante coerentes com as vagas para as quais eram enviados. A Kunla estava, pela primeira vez, entregando velocidade e assertividade, que era, para os sócios, a definiç̧ão de qualidade para o serviço de recrutamento e seleção para posições operacionais.

Ao final do mês, apesar do sucesso na entrega do serviço, nenhuma vaga havia sido fechada. Vagas novas estavam entrando, agentes novas também; elas estavam sendo ativadas e capacitadas, estavam enviando currículos de forma rápida e com bastante assertividade, mas os empregadores não estavam entrevistando. A Kunla seguia o fluxo de negócio de uma consultoria de recrutamento e seleção: pegava uma vaga, encontrava candidatos, enviava ao cliente e esperava que o cliente agendasse uma entrevista para selecionar aquele a ser contratado. Os clientes das consultorias, assim como os da ADS, são grandes empresas com processos de recrutamento e seleção maduros e alinhados com esse fluxo de trabalho. Os clientes que estavam sendo captados em campo pela Kunla tinham perfil muito diferente, no entanto eram pequenos comércios que estão acostumados a colocar uma placa de "contrata-se" na porta e entrevistar os profissionais que se apresentam. Se gostavam do profissional, contratavam-no. A Kunla estava demandando desses empresários o esforço de verificar e-mail, avaliar currículos, ligar para candidatos e agendar entrevistas. Nenhum deles o fez. Os empregadores não contratavam porque não entrevistavam, a Kunla estava impondo uma complexidade adicional à rotina de trabalho do pequeno empresário, e não uma facilidade. Ficou evidente que modelos de clientes distintos demandavam modelos operacionais distintos, e para isso uma nova prática deveria ser testada no próximo ciclo, a de pré-agendamento. Toda vaga anunciada teria a data e o horário de entrevista informados, dessa forma o anunciante já comprometia a agenda e definia expectativa de prazo de envio de candidatos.

O mês de fevereiro terminou com entusiasmo ainda maior do que começara: a Kunla havia encontrado uma forma de obter vagas operacionais suficientes para começar a rodar o negócio, a captação das agentes continuava satisfatória, a capacitação, de forma simplificada, havia sido bem-sucedida, e o serviço das agentes havia alcançado um bom patamar de qualidade. Para os sócios, só faltava o empregador entrevistar os candidatos para o ciclo fechar com sucesso, e a aposta estava no pré-agendamento. 


\subsubsection{Mapa Visual}

Figura 35 - Mapa visual do décimo ciclo

\begin{tabular}{|l}
\hline Reflexões: \\
1. Vagas novas estavam \\
entrando, agentes novas \\
também; elas estavam \\
sendo ativadas e \\
capacitadas, $r$ estavam \\
enviando currículos de \\
forma rápida e com bastante \\
assertividade, mas os \\
empregadores não estavam \\
entrevistando; \\
2. Kunla estava demandando \\
dos pequenos empresários o \\
esforço de verificar e-mail, \\
avaliar currículos, ligar para \\
candidatos e agendar \\
entrevistas. Nenhum deles o \\
fez; \\
Nova prática deveria ser \\
testada no próximo ciclo, a \\
de pré-agendamento de \\
entrevistas.
\end{tabular}

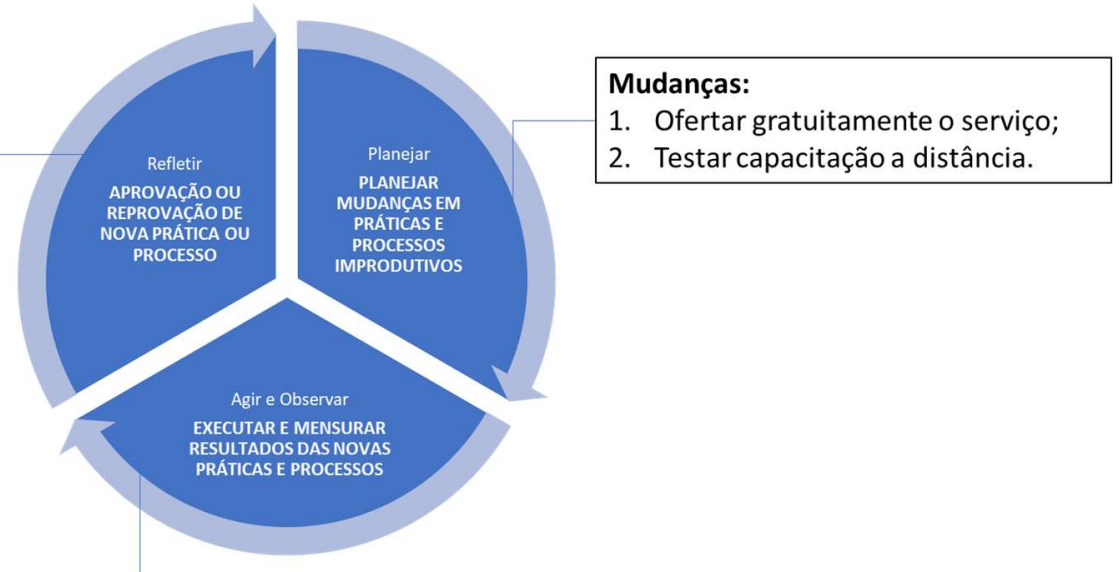

\section{Resultados:}

1. Oferta do serviço gratuito funcionou, de dez a vinte vagas foram abertas semanalmente;

2. Capacitação funcionou, os candidatos enviados tinham os currículos certos para as vagas. A Kunla estava, pela primeira vez, entregando velocidade e assertividade.

3. Nenhuma vaga foi fechada.

Fonte: Elaborada pelo autor (2018).

Figura 36 - Itens provados após décimo ciclo

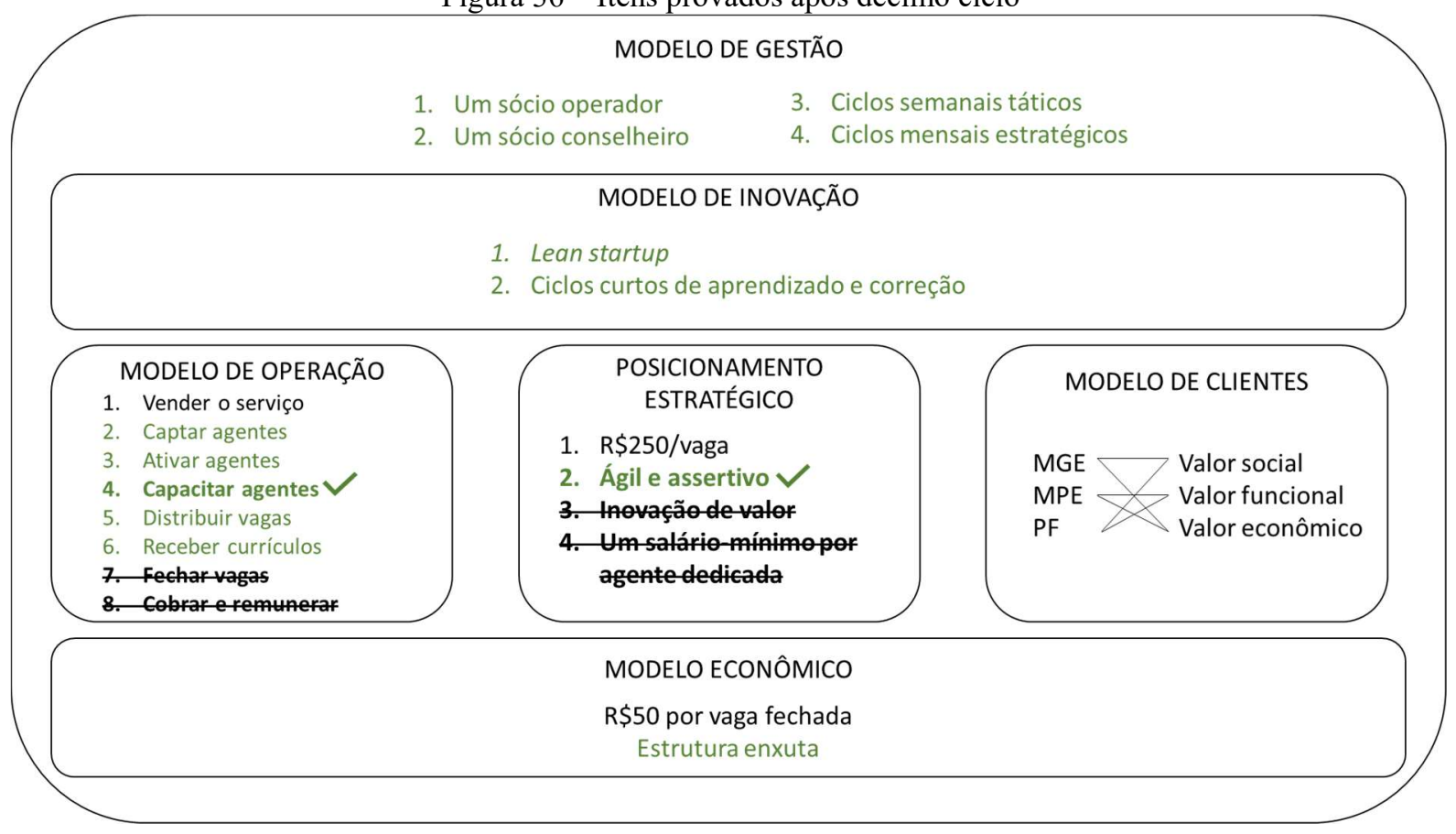

Fonte: Elaborada pelo autor (2018). 


\subsection{Décimo Primeiro Ciclo}

\subsubsection{Narrativa}

O décimo primeiro ciclo começou com um objetivo simples: captar vagas com entrevistas pré-agendadas. Os sócios acreditavam que esse simples ajuste seria suficiente para, finalmente, validarem o modelo de negócio. Apesar do claro objetivo definido para a operação, a Kunla estava imersa em questões paralelas que ofuscaram a capacidade da empresa de focar e executar o ciclo programado.

Em março de 2018 a Kunla via a aproximação do fim do capital inicial investido pelos sócios e, por ainda não ter validado seu modelo, não havia perspectiva de entrada de novos investidores. Esse cenário foi especialmente impactante para o sócio operador que há um ano estava trabalhando sem remuneração. Ao mesmo tempo que via seus esforços sendo em vão, sofria pressões de agentes externos para dissolução da sociedade como forma de saneamento das finanças. Esses agentes lhe prometiam que, uma vez que o sócio conselheiro deixasse o negócio, a empresa receberia investimento e ele passaria a ser remunerado.

A tensão gerada pelos sucessivos insucessos na operação, pela aproximação do fim dos recursos financeiros da empresa e pelas pressões de agentes que buscavam participação no negócio gerou um distanciamento entre sócios operadores e conselheiro. Ao longo do mês o distanciamento se tornou tamanho que o diálogo foi rompido, os ciclos semanais abandonados, a operação não teve qualquer evolução ou aprendizado e, ao final, a Kunla não tinha vagas e havia reduzido drasticamente seu número de agentes. Os objetivos haviam sido perdidos, a operação foi colocada de lado e isso deu espaço para o questionamento sobre a estrutura societária e as finanças da empresa.

Após dez meses de empreendimento, a Kunla havia experimentado pela primeira vez um mês sem qualquer evolução ou aprendizado, nenhuma dimensão do modelo de negócio havia evoluído e, além disso, as duas dimensões validadas no primeiro ciclo entraram em colapso: modelo de inovação e modelo de gestão. A história da Kunla apontava para o fracasso de uma ideia que falhou na execução e padeceu na discórdia entre os sócios. 


\subsubsection{Mapa Visual}

Figura 37 - Mapa visual do décimo primeiro ciclo

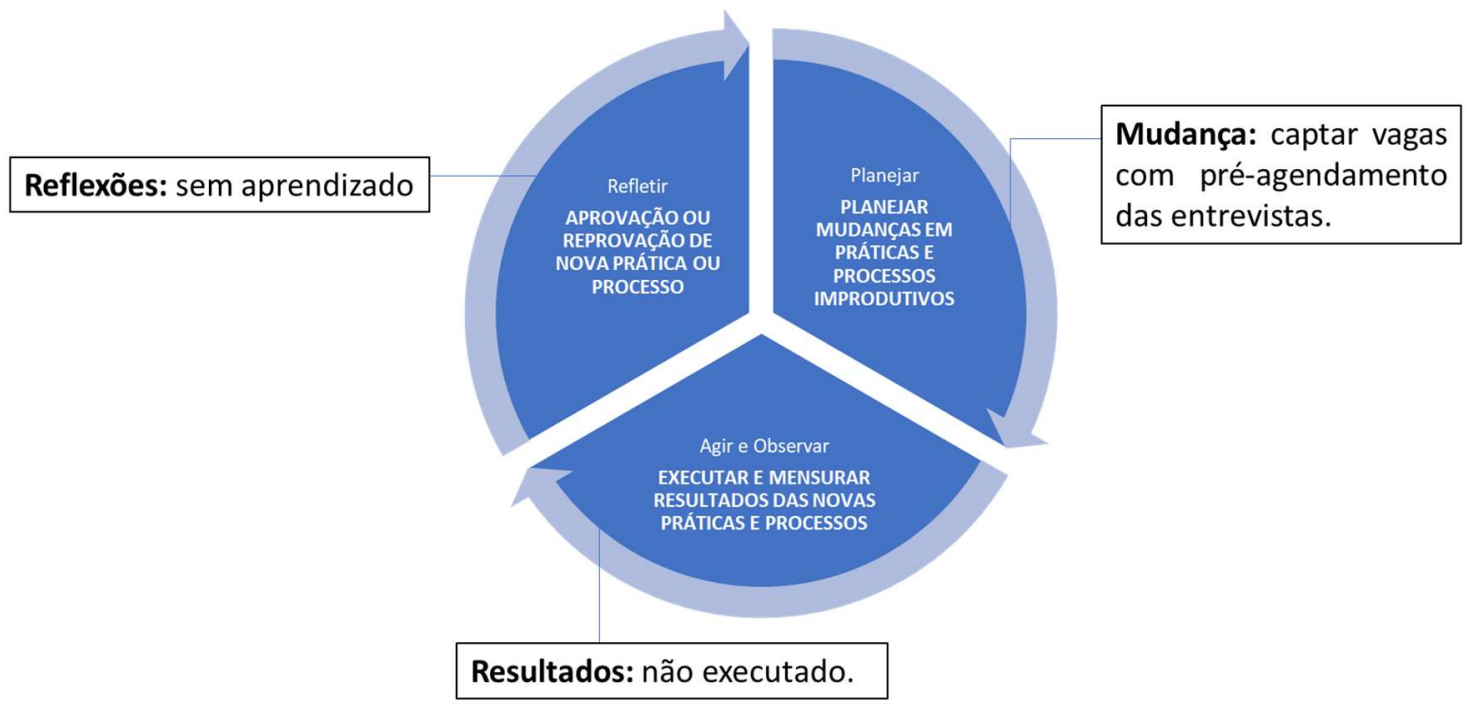

Fonte: Elaborada pelo autor (2018).

Figura 38- Itens provados após décimo primeiro ciclo

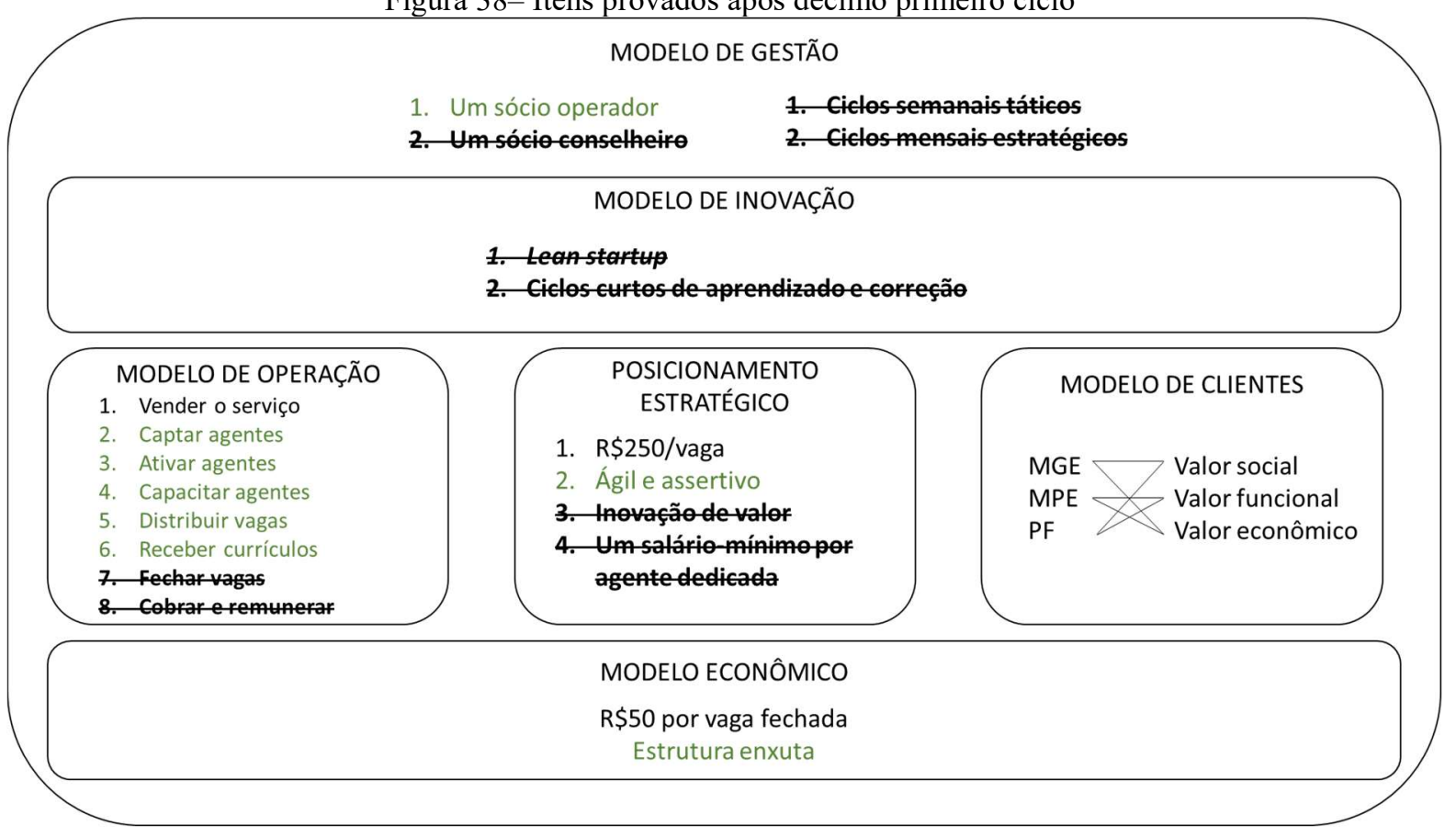

Fonte: Elaborada pelo autor (2018). 


\subsection{Décimo Segundo Ciclo}

\subsubsection{Narrativa}

O último ciclo do estudo começou não com os objetivos a serem alcançados, mas com a solução do impasse entre os sócios, que se reuniram para sanar a situação da sociedade e do próprio negócio. O sócio operador entendia que a saída do sócio conselheiro seria uma chave para o sucesso da Kunla, que o insucesso do empreendimento se devia à falta de recursos financeiros e que esta seria sanada com a mudança societária. No entanto, não havia qualquer proposta formal, ou mesmo informal, que revelasse o montante e as condições do investimento pelos agentes externos. Após reflexão sobre o que estava ocorrendo, os sócios concluíram que os agentes não tinham propostas, tinham apenas o objetivo de simplificar a estrutura societária e deixar um único sócio em situação frágil (restrição financeira pessoal e apego ao negócio), para que pudessem barganhar o investimento e ter maior influência e controle após o aporte. Esse cenário já havia sido antecipado ao sócio operador por um advogado e mentor com quem conversara meses antes. Tal era o modelo de ação dos investidores: dividir para conquistar.

Em análise sobre os efeitos do ocorrido ao longo do último mês, os sócios constataram que a Kunla possuía apenas dois ativos, a ideia conceitual do negócio e os modelos de gestão e inovação, e que perdera o último. O entendimento sobre o ocorrido precedeu a solução para a situação em que a Kunla se encontrava. Era preciso validar o modelo e levantar mais capital para prolongar a vida do empreendimento. O capital externo se mostrou extremamente caro para a unidade da sociedade. Portanto, seria necessário capital dos próprios sócios. Foi definido que o sócio operador deixaria a operação, teria um emprego remunerado e permaneceria responsável pelo desenvolvimento e sustentação da parte tecnológica do negócio. Dessa forma o sócio operador poderia solucionar suas finanças pessoais e ainda aportar recursos à Kunla, uma vez que o sócio conselheiro não possuía recursos suficientes para fazê-lo sozinho.

O sócio conselheiro passou a ser responsável pela operação, aplicando o modelo de gestão que tivera sucesso na construção da ADS (um coordenador sendo gerido de forma remota e responsável pela operação e por funcionários) e ainda implementando ajuste no modelo operacional para assegurar a oferta do serviço.

A Kunla iniciara o mês com uma pequena base de agentes ativas que deixava o antigo sócio operador inseguro para assumir compromissos na venda do serviço. Esta situação gerava um ciclo vicioso que deixava a Kunla imóvel e sem reação: faltavam agentes por falta de vagas 
e faltavam vagas por falta de agentes. O novo modelo operacional adotou dois conceitos: o de modelo operacional transitório e o de garantia de oferta de serviço no modelo de negócio orquestrador. Para assegurar a oferta do serviço de R\&S, o novo operador decidiu criar uma estrutura interna de recrutamento e seleção da Kunla e a ela foi dada o nome de estrutura garantidora do serviço. A partir de então, toda vaga anunciada na Kunla era, ao mesmo tempo, encaminhada às agentes e conduzidas internamente. Ao final do prazo de envio de candidatos, os candidatos das agentes teriam preferência, e se não houvesse número suficiente ele seria complementado com os candidatos selecionados pelo processo interno da Kunla. Esse artifício deu segurança à Kunla para investir no processo de venda do serviço, que teve grande sucesso já em sua primeira semana, com sete reuniões comerciais agendadas com grandes empresas.

Além da mudança no modelo de entrega, foi implementada também uma mudança no modelo de construção e gestão da cadeia de agentes. Foi definido que a Kunla iria operar com trinta a quarenta agentes ativadas e capacitadas até que elas estivessem em seu limite produtivo. Essa mudança de diretriz objetivava aumento de produtividade, remuneração e retenção das agentes e ainda simplificação da relação Kunla-agente. Uma pessoa ficou responsável pela gestão de toda a base: relacionamento, capacitação e entrega de candidatos através da cadeia. A figura da consultora de campo foi extinta e o turnover, já reduzido, foi compensado pela entrada de novas agentes por indicação.

A estrutura da Kunla foi reduzida a quatro colaboradores, um coordenador geral, com reporte geral ao sócio operador, e três funcionários com reporte ao coordenador, cujas atividades individuais eram: (1) venda do serviço; (2) R\&S interno; e (3) R\&S através de agentes.

Ao final do mês a Kunla possuía três clientes ativos, três grandes contratos em negociação, nenhuma vaga perdida, seis vagas fechadas (todas com agentes) e 38 candidatos em processo de seleção em cliente. O resultado das agentes foi tão positivo que a percepção era que o recurso de R\&S interno não duraria mais de seis meses na cidade de São Paulo, mas seria uma ferramenta valiosa para a entrada em novos mercados (já havia demanda do serviço em três outras cidades e Estados), pois permitiria criar a demanda antes de estruturar a oferta. Estava provado que a Kunla era capaz, em pequena escala, de percorrer todo as atividades do modelo de operação, o próximo passo seria fazê-lo com alto volume de vagas. 


\subsubsection{Mapa Visual}

Figura 39 - Mapa visual do décimo segundo ciclo

\section{Reflexões:}

1. 0 resultado das agentes

foi tão positivo que a percepção era que o recurso de R\&S interno não duraria mais de seis meses na cidade de São Paulo, mas seria uma ferramenta valiosa para a entrada em novos mercados (já havia demanda do serviço em três outras cidades e Estados), pois permitiria criar a demanda antes de estruturar a oferta.

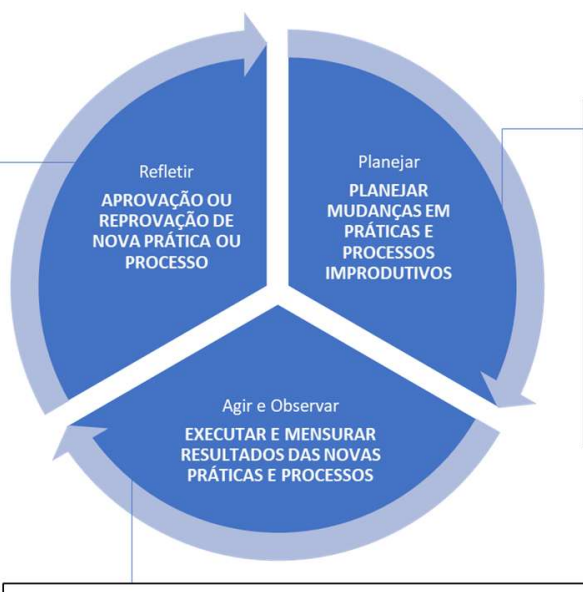

Mudança:

1. Inversão de papéis entre os sócios;

2. Adoção de recrutamento interno como garantidor do serviço para novos clientes;

3. Redução do número de agentes;

4. Estruturação da equipe em: (1) venda do serviço; (2) R\&S interno; e (3) R\&S através de agentes.

\section{Resultados:}

1. Três clientes ativos, três grandes contratos em negociação, nenhuma vaga perdida, seis vagas fechadas (todas com agentes) e 38 candidatos em processo de seleção em cliente;

Fonte: Elaborada pelo autor (2018).

Figura 40 - Modelo de negócio ao término do décimo segundo ciclo

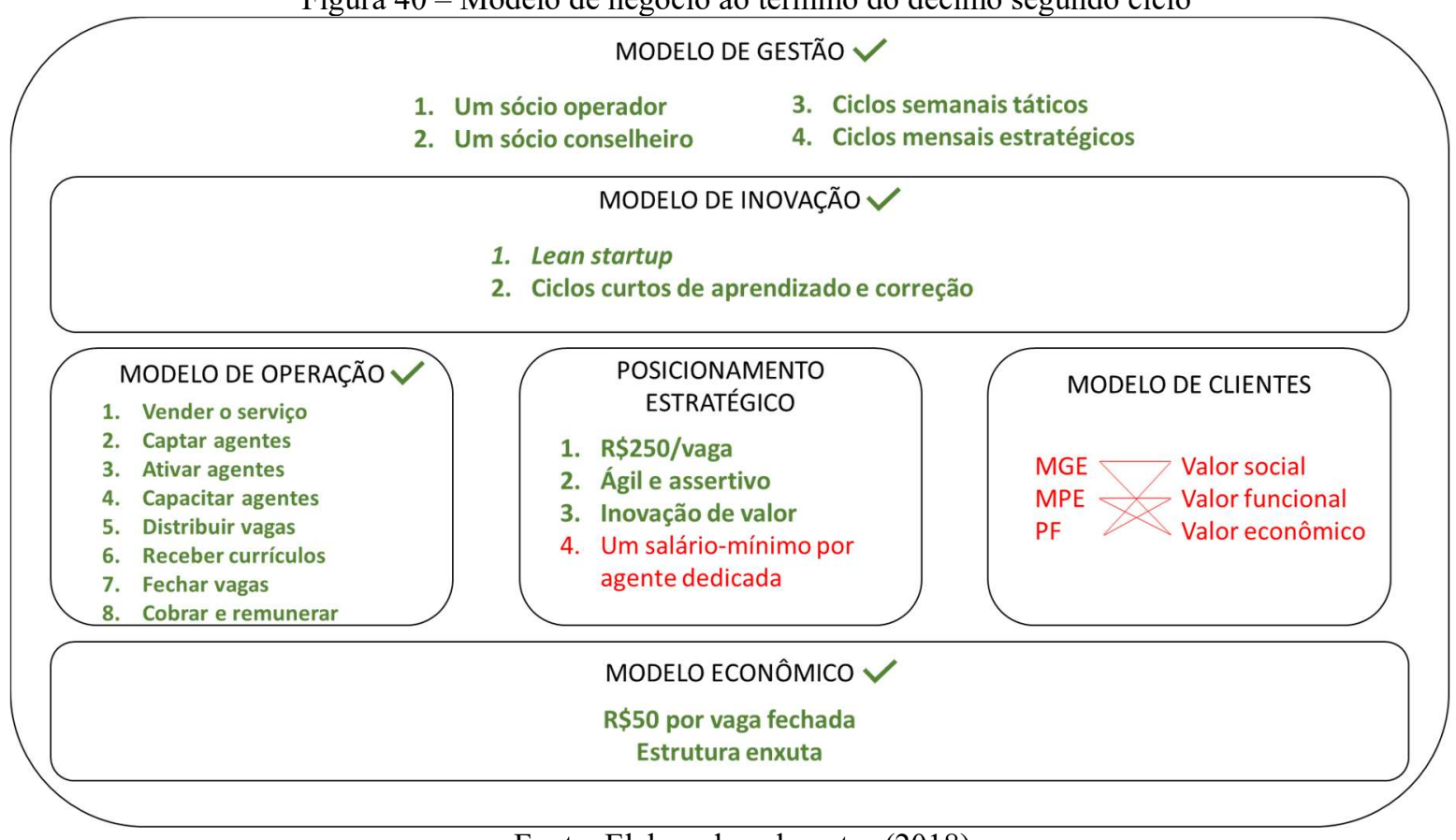

Fonte: Elaborada pelo autor (2018). 


\section{ANÁLISE DA JORNADA}

A jornada de dois anos do estudo levou a uma profunda transformação no modelo de negócio de recrutamento e seleção dos sócios. A ADS, empresa-alvo da intervenção, foi reposicionada e se tornou uma consultoria especializada em recrutamento e seleção de pessoas com deficiências, ao passo que uma nova empresa surgiu como resposta ao questionamento sobre um modelo de negócio inclusivo no mercado de recrutamento e seleção. Ao término do estudo, a ADS já era uma empresa superavitária e em franca expansão, com uma carteira de clientes saudável e já reconhecida no mercado pela sua expertise. A Kunla, apesar de não ser considerada uma empresa plenamente operacional, atendeu ao objetivo do estudo ao encontrar um modelo operacional de recrutamento por rede capaz de entregar o serviço proposto. $\mathrm{O}$ modelo operacional da empresa se mostrou significativamente mais complexo que o inicialmente imaginado: construir um negócio inclusivo no qual o grupo impactado faz parte da cadeia produtiva demandou capacitação desse grupo e a demora na aceitação dessa característica retardou a descoberta do modelo operacional viável. Todo o processo de descoberta foi conduzido com a participação ativa do grupo impactado que, através de contato direto e constante com a Kunla, apontava e sugeria práticas para melhora na comunicação e na construção do conhecimento da atividade de recrutamento e seleção. Ao final da intervenção, o modelo a ser tracionado estava definido.

O impacto social gerado pela Kunla durante o período foi irrisório perto do investimento realizado, uma vez que seu resultado operacional também fora muito limitado. A Kunla optou pela amplitude do seu impacto social, medido pela renda gerada pelas agentes, em detrimento da profundidade, estando este, portanto, atrelado à escala da operação. É compreensível que negócios com sustentação em alta escala não justifiquem os seus investimentos nos primeiros meses de operação. A grande conquista que tais negócios podem fazer nos primeiros meses é encontrar o modelo apto a ser escalado. Apesar do mínimo impacto social gerado no período, a construção e a validação do modelo criaram as bases para o empreendimento expandir sua operação e gerar o almejado impacto de grande escala.

Ao longo do estudo foi relatado aos sócios outros dois impactos não percebidos inicialmente sobre a atividade da Kunla. O primeiro foi definido como "democratização das oportunidades de trabalho" dentro das comunidades, e veio de uma associação da comunidade de Heliópolis. Segundo os moradores, ter acesso às informações das vagas já era uma grande contribuição para a comunidade, pois democratizava a concorrência pela posição de trabalho. 
O segundo partiu das próprias agentes, que relataram que, ao aprenderem a recrutar e selecionar, aprenderam também a ser boas candidatas e passaram a buscar oportunidades no mercado. Uma das mais produtivas agentes da Kunla conseguiu emprego e relatou que isso não teria acontecido se não fosse a sua experiência como agente. Curiosamente, essa agente não fechou vaga, não foi remunerada pela atividade de agente de recrutamento e seleção, mas foi recompensada com um emprego que lhe gerou renda suficiente para pagar uma cuidadora e as despesas da casa.

Em contrapartida, os sócios aprenderam durante a experiência que havia um extrato social que não conseguiria ser atendido pela Kunla. As consultoras Kunla visitaram inúmeras comunidades durante o período, que variavam de ocupações recentes a favelas já urbanizadas. $\mathrm{O}$ valor imobiliário e os perfis sociais residentes nessas comunidades são muito distintos e os mais necessitados se mostraram menos aptos para produzirem através da Kunla. A Kunla se mostrou uma ferramenta útil para um extrato que necessita dela, mas não para o extrato que mais usufruiria do valor gerado pela atividade. Para romper com a decepção gerada nos sócios e na equipe por essa constatação, foi adotada a visão de que a Kunla deveria trabalhar pelos que ela poderia ajudar e não se abalar com os que estavam além da competência da empresa.

Os fatores de sucesso encontrados no estudo do Projeto Kiteiras da Danone foram de grande relevância para se entender da razão de seu sucesso. A Danone precisou encontrar um parceiro capaz de entrar em comunidades, construir relações com lideranças e alcançar as mulheres do local. A Kunla trilhou, desde o princípio, o mesmo caminho: alguém capaz de entrar em comunidades, construir parcerias e falar diretamente com as mães. A consultora Kunla, primeiro cargo contratado na empresa, foi essencial como elo de conexão da plataforma com o grupo impactado. A análise do caso auxiliou, portanto, no entendimento do que precisava ser construído (ponte entre empresa e comunidade), apesar de não ter sido adotada a forma com que foi feita essa construção (parceria com uma grande ONG).

Apesar de Pedroso (2016) considerar que o estudo de modelos de negócios tenha menor relevância para empresas em fase de lançamento, a arquitetura de modelos de negócios do autor revelou-se valiosa no planejamento e entendimento das mudanças da empresa. As duas dimensões dinâmicas (modelo de gestão e modelo de inovação) se mostraram altamente relevantes no cenário de startup, uma vez que no momento mais crítico do empreendimento a visão estruturada sobre o negócio e o entendimento do valor de seus modelos de inovação e gestão foram cruciais para a reaproximação dos sócios e afastamento dos agentes externos causadores de desavenças. Se os modelos de análise de negócios baseados em quatro dimensões se mostram mais relevantes para empreendimentos já maduros (PEDROSO, 2016), a inserção 
das dimensões de modelo de gestão e modelo de inovação faz da arquitetura uma ferramenta poderosa para empresas nascentes que comumente não podem contar com mais do que uma ideia e uma forma de tentar implementá-la (modo de gerir e de adaptar-se). Os modelos de gestão e inovação definem o modo como é feita a gestão da mudança, uma característica intrínseca às startups que ainda não possuem as demais dimensões validades (modelo de operação, posicionamento estratégico, modelo de clientes e modelo econômico).

Ademais, a clareza nos modelos de gestão e de inovação podem não só contribuir para o sucesso do empreendimento mas também transmitir segurança a investidores na avaliação da liderança e da equipe, dois dos elementos identificados como chaves na análise de projetos por FIs.

Os ciclos de desenvolvimento ágil de Ries (2011) adaptados para o desenvolvimento de um negócio inclusivo se mostraram produtivos. Apesar de o autor sustentar seu modelo através de ferramentas cujas aplicações estão no mercado de desenvolvimento de softwares, o conceito de fazer pequenas alterações e testar aplicabilidade em ciclos curtos pôde ser adaptado para o estudo com sucesso. Essa metodologia de desenvolvimento ágil é particularmente interessante para cenários de incerteza quanto ao produto ou negócio ou, ainda, em cenários onde sabidamente haverá alto índice de erros na execução. Desde o princípio os sócios sabiam que estavam empreendendo um modelo de negócio que desconheciam. Nenhum dos sócios tinha experiência em modelos de negócios orquestradores, tampouco em negócios inclusivos, e ainda não tinham conexão direta com o grupo impactado pelo empreendimento (mães em comunidades). $\mathrm{O}$ alto nível de desconhecimento sobre o que estavam por fazer criava um cenário de grandes incertezas e garantia de erros recorrentes na execução, apesar dos estudos que precederam a implantação. A estratégia de errar pequeno e corrigir rapidamente foi benéfica para o empreendimento, que em onze meses conseguiu encontrar o seu modelo operacional viável (Figura 40).

Apesar de a pesquisa ter levado a Kunla a um modelo operacional viável, ela não logrou encontrar um modelo de negócio viável porque não houve tempo hábil para validação de seu posicionamento estratégico (um salário-mínimo por agente dedicada) e de seu modelo de clientes (Figura 40). Ao término dos onze ciclos de desenvolvimento da Kunla, as barreiras da empresa estavam limitadas ao seu modelo comercial e à escala da operação que ele traria. A remuneração idealizada por agente ainda não havia sido alcançada devido à ausência de volume relevante de vagas (dez vagas para cada agente), e apenas uma atividade comercial de alta escala poderia solucionar a questão. A Kunla possuía um modelo operacional comprovado, as agentes 
entregavam um serviço ágil e assertivo, havia inovação de valor no negócio e ela estava pronta para levar sua operação para grande escala. 


\section{CONSIDERAÇÕES FINAIS E RECOMENDAÇÕES}

Ao longo da jornada de pesquisa, os sócios da empresa depararam com a recorrente máxima de que um negócio inclusivo deve ser constituído por empreendedores que conhecem em profundidade a realidade do grupo impactado. Apesar da difusão da ideia de que a maior probabilidade de sucesso do empreendimento está correlacionada a este fator, o caso relatado traz uma prática divergente que vale um aprofundamento de pesquisa: a construção de um negócio inclusivo a partir da expertise do mercado do fundador. A difusão da prática de criação de modelos de negócios inclusivos constituídos por profissionais de mercado, que buscam, para seus setores, soluções a partir de impacto social, pode contribuir positivamente para o aumento do número de empreendimentos de impacto social e amadurecimento do ecossistema. Esses profissionais, mesmo não possuindo profundo conhecimento do grupo impactado em suas soluções, podem contribuir para o empreendimento através do amplo conhecimento do mercado em que atuam, enquanto que o conhecimento social pode ser aportado por profissionais que venham a compor a equipe de negócio.

A experiência obtida no uso da arquitetura de Pedroso (2016) aponta para a recomendação de um fluxo de validação e implantação de um negócio inclusivo. O autor propõe que o estudo de um negócio, ou desenho de um novo empreendimento, pode começar por qualquer dimensão. $\mathrm{O}$ aprendizado desse estudo indica, no entanto, que a validação do modelo deva seguir um fluxo predefinido.

Na proposta de fluxo de validação, o primeiro passo é o modelo de gestão e, na sequência, o modelo de inovação. A importância da validação desses modelos será crucial na jornada de validação das dimensões seguintes. Um empreendimento em fase inicial, particularmente um que traz inovação de processos, como os negócios inclusivos, traz consigo incertezas quanto sua capacidade de gerar, entregar e capturar valor (dimensões estáticas). A validação destas dimensões é sustentada por modelos de gestão e de inovação, sejam eles planejados e controlados ou intuitivos e espontâneos. Inevitavelmente haverá insucessos nas validações das dimensões estáticas, seguidos de ajustes e novos testes. Este ciclo de aprendizado, por si só, é parte da forma de inovar e gerir de um novo empreendimento e, portanto, está presente na atividade da empresa antes mesmo das dimensões estáticas serem validadas. A questão, portanto, é: as dimensões dinâmicas, que já estão presentes no negócio desde o início de suas atividades, não deveriam ser as primeiras a passarem pelo rigor do planejamento e aprovação? A resposta, a partir deste estudo, é que sim. Os ciclos de 
aprendizado e desenvolvimento dos ciclos seguintes foram suportados por uma forma préestabelecida de gerir e inovar, cujas ausências quase certamente gerariam falta de rigor no processo de aprendizado e, consequentemente, descontrole. Ainda, foi a compreensão e planejamento das dimensões dinâmicas que permitiu aos sócios superarem o momento mais crítico da Kunla. Pedroso (2016), ao incluir as dimensões estáticas em sua proposta de arquitetura de negócios, realça a importância do "como gerir e inovar" na prática de estudo e modelagem de negócios. O entendimento de que a validação das dimensões dinâmicas precede às estáticas em novos empreendimentos reforça essa visão e argumenta a favor da adoção da arquitetura de Pedroso (2016) por empreendedores.

A terceira etapa a ser validada é modelo de operação, a dimensão onde, por definição, está a inovação social e de processos em um negócio inclusivo. Uma vez comprovado o modelo de operação, é possível verificar se o posicionamento estratégico de fato é entregue pelo modelo desenhado, permitindo o retorno e a correção da etapa anterior. Em posicionamento estratégico de empreendimentos de impacto social recomenda-se o tratamento da dualidade de valor social (grupo impactado) e financeiro (grupo de sustentação financeira do modelo) no processo de validação. Uma vez validada a proposta de valor, o modelo de clientes pode ser validado e, em caso de rejeição do modelo, a dimensão que a antecede, pode ser alterada em cadeia. A última validação, do modelo econômico, só pode ser executada após validação das três dimensões anteriores, uma vez que é o resultado financeiro dos modelos executados. Diante da invalidação do modelo econômico, recomenda-se revisão da dimensão anterior e, se necessário, das que a precedem, de forma linear e em cadeia para gestão e controle da mudança (Figura 41). 
Figura 41 - Fluxo de validação de dimensões

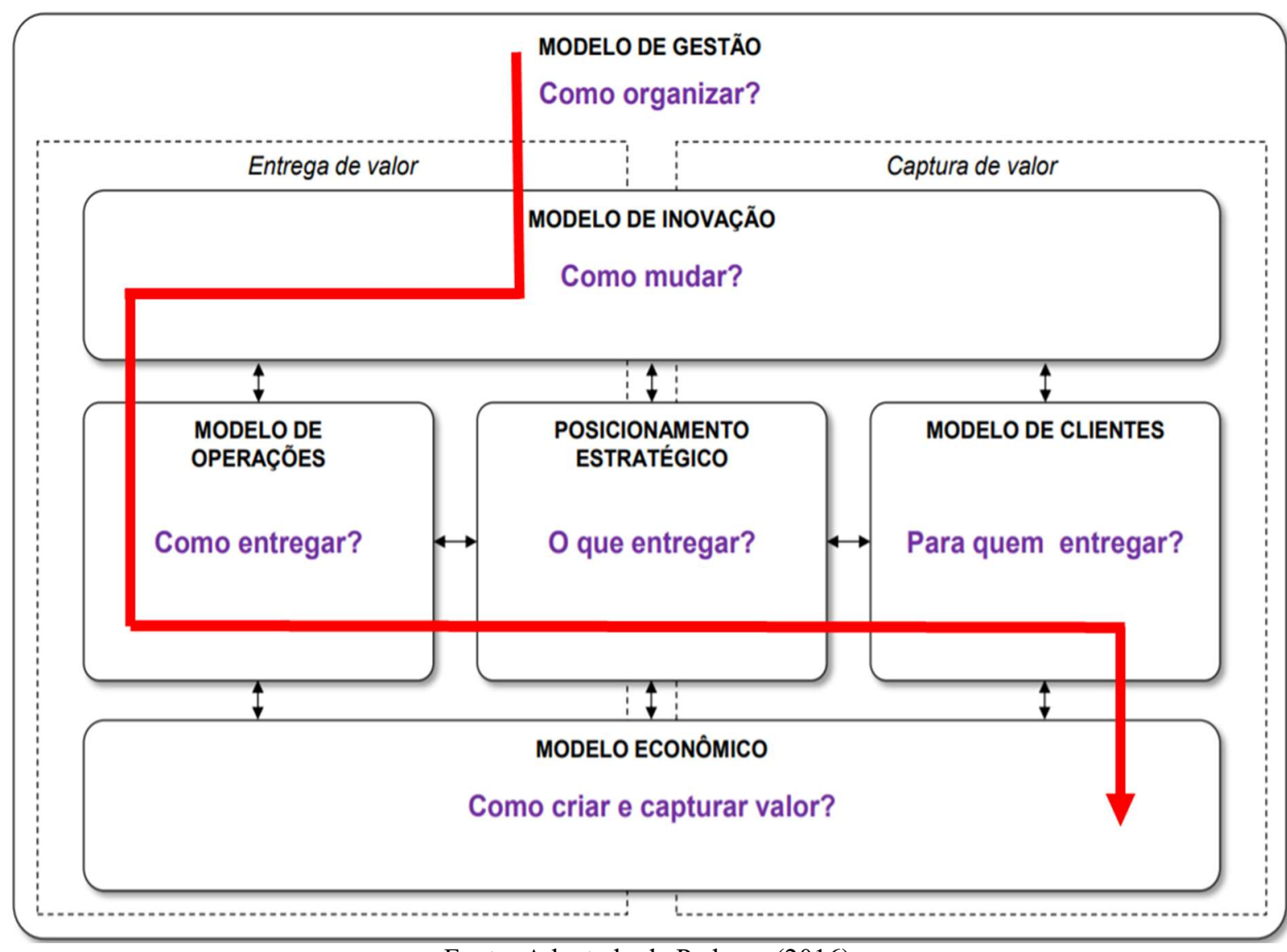

Fonte: Adaptado de Pedroso (2016).

A metodologia de lean startup e a mentalidade empreendedora que permearam a pesquisa criaram uma forma de encarar a pesquisa não como uma ação de testar a viabilidade de uma solução, mas como uma ação de encontrar a forma viável de implantar a solução. A cultura da prática empreendedora teve forte influência sobre o método de pesquisa, não aceitando a rápida conclusão de "não viável” para a intervenção. Os sócios sempre mantiveram a linha de pensamento de que empreender era uma atividade de descobrir como o negócio pode dar certo e não se o negócio dá certo.

Apesar das agruras dos sócios para a viabilização do modelo de operação, a proposta de modelo de negócios gerada pelas etapas da pesquisa de investigação e proposição se apresentou bastante atrativa para os meios de comunicação e parte do ecossistema de negócios de impacto. Foi o modelo de negócios, mais especificamente a proposta de valor e modelo de operações, somado à comunicação visual profissional da empresa, que atraiu a grande mídia e as aceleradoras de impacto. A clareza de propósito e a consistência de planejamento, cuidadosamente comunicados, aumentaram o valor percebido de um empreendimento que ainda não havia conseguido viabilizar seu modelo. 


\section{LIMITAÇÕES DE PESQUISA}

A pesquisa assumiu um grande escopo de intervenção no momento em que um novo empreendimento foi definido como a solução para o problema de pesquisa. A criação de uma nova empresa engloba inúmeros temas da administração, e o estudo limitou o relato e a análise ao modelo de negócios e, mais especificamente, ao modelo operacional. Ademais, dentro do modelo de negócios, o modelo financeiro foi simplificado no estudo, apesar de ter sido detalhadamente trabalhado na prática. O principal motivo das simplificações adotadas foi o compromisso com o foco da pesquisa e o prazo. Apesar de a pesquisa permitir focar o relato nos temas centrais do estudo, a prática demanda cuidado com todos os temas que cercam a atividade da empresa, e isso consome tempo e esforço do pesquisador. A pesquisa foi conduzida ao longo de dois anos e meio, período que se mostrou insuficiente para percorrer ciclos de aprendizados até o ponto de validação integral do modelo de negócio. De fato, apenas a validação do modelo de negócio pode levar três ou mais anos, tempo incompatível com uma pesquisa de mestrado.

A limitação de tempo também acarretou em simplificações nas etapas de investigação e proposição da solução. Uma maior profundidade de pesquisa na literatura sobre negócios inclusivos, assim como uma maior amplitude de análise de casos, que ficou restrito ao caso Kiteiras, poderia ter contribuído para uma proposição de solução inicial mais assertiva.

Além da limitação de tempo, a restrição de recursos financeiros também refreou a evolução da pesquisa. Apesar de o reconhecimento da restrição financeira para o empreendimento e da importância de torná-lo atrativo para investidores ser parte do relato da pesquisa, a mudança desse cenário, com maior disponibilidade inicial de recursos, poderia ter acelerado os ciclos de aprendizado e, consequentemente, a validação do modelo de negócio. Outra restrição sofrida na pesquisa foi a baixa demanda por serviço de recrutamento e seleção, ocasionada pela superoferta de profissionais em um mercado de taxa de desemprego recorde no país. O cenário enfrentado pela Kunla durante a pesquisa foi de empresas com contratações suspensas ou, quando contratando, fazendo o processo de R\&S internamente com o objetivo de reduzir custos. 


\section{REFERÊNCIAS}

AREND, Richard J. The business model: Present and future - beyond a skeumorph. Strategic Organization, 390-402, 2013.

AUSTIN, James. "Prólogo." em Socially Inclusive Business: Engaging the Poor through Market Initiatives, por Patricia Márquez, Ezequiel Reficco and Gabriel Berger, vii-ix. Cambridge,Massachusetts: Harvard University Press, 2010.

AUSTIN, James; STEVENSON, Howard; WEI-SKILLERN, Jane. Social and commercial entrepreneurship: same, different, or both? Entrepreneurship: Theory and Pratice Journal 30, n. 1, jan. 2006, 1-22.

BARKI, Edgard; IZZO, Daniel; TORRES, Haroldo da G.;AGUIAR, Luciana. Negócios com impacto social no Brasil. São Paulo: Peirópolis, 2013.

BESANKO, D.; DRANOVE, D.; SHANLEY, M.; SCHAEFER, S. A economia da estratégia. Porto Alegre: Bookman, 2012.

BOCK, Adam J.; OPSAHL, Tore; GEORGE, Gerard; GANN, David M. The effects of culture and structure on strategic flexibility during business model innovation. Journal of Management Studies, 2012, 279-305.

BORGES, Cândido et al. Empreendedorismo Sustentável: Proposição De Uma Tipologia E Sugestões De Pesquisa. Regepe 2, 2013, 77-100.

BORZAGA, Carlo; DEPEDRI, Sara; GALERA, Giulia. Interpreting social enterprises. R.Adm. 47, n. 3 (jul/ago/set. 2012), 398-409.

BOWMAN, Cliff; AMBROSINI, Véronique. Value Creation Versus Value Capture: Towards a Coherent Definition of Value in Strategy. British Journal of Management, 2002: 1-15.

BURKETT, Ingrid. Business Model for Social Enterprise Design. Business Model for Social Enterprise Design. n.d. Disponível em: < https://mbs.edu/getmedia/91cc0d01-3641-4844b34c-7aee15c8edaf/Business-Model-for-SE-Design-Burkett.pdf>. Acesso em: 10 mar. 2017.

CERVO, Amado Luiz; SILVA, Roberto da; BERVIAN, Pedro A. Metodologia Científica. São Paulo: Prentice Hall, 2006.

CHU, Michael. Commercial returns at the base of the pyramid. Innovations, 2007, 115-146.

CLARK JR., William H.; BABSON, Elizabeth. How Benefit Corporations are redefining the purpose of business corporations. Wm. Mitchell L. Rev. 38, 2011, 817.

COMINI, Graziell; BARKI, Edgard; AGUIAR, Trindade Luciana de. A three-pronged approach to social business: a Brazilian multi-case analysis. São Paulo: Revista da Administração, 2012. 
COMINI, Graziella M. Negócios sociais e inovação social: um retrato de experiências brasileiras. São Paulo, 2016.

COSTA FILHO, Edson Renel, PEDROSO, Marcelo Caldeira. Pesquisa-ação e process studies como métodos para pesquisas de natureza aplicada. SEMEAD, 2018.

COUGHLAN, Paul, COUGHLAN, David. Action research for operations management. International Journal of Operations \& Production Management, v. 22, n: 2, p. 220-240, 2002.

CUMMINGS, Briana. Benefit corporations: How to enforce a mandate to promote the public interest. Columbia Law Review, 2012, 578-627.

CVM. Lista de Fundos de Participações. Dezembro 01, 2016. Disponível em:

$<$ http://cvmweb.cvm.gov.br/SWB/Sistemas/SCW/CPublica/ResultListaPartic.aspx?TPConsul $\mathrm{ta}=23 \&$ TPPartic $=73>$. Acesso em: 04 jan. 2017.

DANONE. Danone - Kiteiras. 05 01, 2016. Disponível em:

$<$ https://corporate.danone.com.br/br/descubra/sustentabilidade/kiteiras/>. Acesso em: 24 mai. 2016.

DEES, J. Gregory. The Meaning of Social Entrepreneurship. Duke Innovation \& Entrepreneurship. Maio 30, 2001. Disponível em: <https://entrepreneurship.duke.edu/newsitem/the-meaning-of-social-entrepreneurship/>. Acesso em: 08 mar. 2017.

DEMIL, Benoît; LECOCQ, Xavier. Business model evolution: in search of dynamic consistency. Long Range Planning, 2010, 227-246.

DEMING, William Edwards. Out of the crisis. Cambridge, Mass: Massachusetts Institute of Technology, Center for Advanced Engineering Study, 1986.

FENN, George; LIANG, Nellie; PROWSE, Stephen. The Economics of the Private Equity Market. Federal Reserve Bulletin, 1996, 1-68.

FORLIN, Gabriela. Fundos Procuram Investimento Social. O Estado de São Paulo. julho 29, 2013. http://economia.estadao.com.br/noticias/geral,fundos-procuram-investimento-socialimp-,1058437. Acesso em: 12 jan. 2017.

FUNDO Écosystème. Danone - Fundo Écosytème. Disponível em:

$<$ http://ecosysteme.danone.com/>. Acesso em: 1 mai. 2016.

GASSMANN, Oliver; FRANKENBERGER, Karolin; CSIK, Michaela. The Business Model Navigator. Harlow: Pearson Education Limited, 2014.

GIL, Antônio C. Como elaborar projetos de pesquisa. 5. São Paulo: Atlas, 2010.

Golja, Tea; POZEGA, Samanta. Inclusive business: what it is all about? Managing inclusive companies. International Review of Management and Marketing, 2012, 22-42.

GOMPERS, Paul; KOVNER, Anna, LERNER, Josh; SCHARFSTEIN, David. Performance persistence in entrepreneurship. Journal of Financial Economics, 2010, 18-32. 
GOVERNO do Estado de São Paulo. SP Notícias. 03 31, 2017. Disponível em: < $<$ http://www.saopaulo.sp.gov.br/spnoticias/alckmin-reajusta-piso-salarial/>. Acesso em: 15 abr. 2017.

GRASSL, Wolfgang. Business Models of Social Enterprise: A Design Approach. Journal of Entrepreneurship Perspectives 1, n. 1, fev. 2012, 37-60.

HARDING, Rebecca. Social enterprise: the new economic engine? Business Strategy Review 15, n. 4, 2004, 39-43.

IIZUKA, Edson Sadao; VARELA, Carmen Augusta; LARROUDÉ, Elisa. Social business dilemmas in Brazil: Rede Asta case. RAE, agosto 2015, 385-386.

ISHIKAWA, Kaoru. What is total quality control? The Japanese way. Englewood Cliffs: Prentice Hall, 1985.

KAPLAN, Steven; SCHOAR, Antoinette. Private Equiity Performance: Returns, Persistence and Capital. Journal of Finance, 2005, 1791-1823.

KIM, W. Chan; MAUBORGNE, Renée. Blue ocean strategy: how to create uncontested market space and make the competition irrelevant. Boston: Harvard Business School Press, 2005.

KOLB, David. Experiential Learning: Experience As The Source Of Learning And Development. Englewood Cliffs, N.J.: Prentice-Hall, 1984.

LAMBERT, Susan C.; DAVIDSON, Robyn A. Applications of the business model in studies of enterprise success, innovation and classification: An analysis of empirical research from 1996 to 2010. European Management Journal, 2013, 668-681.

MAIR, Johanna; MARTI, Ignasi. Social entrepreneurship research: A source of explanation, prediction, and delight. Journal of World Business 41, 2006: 36-44.

MAKADOK, Richard; COFF, Russell. The theory of value and the value of theory: Breaking new ground versus reinventing the wheel. Academy of Management Review, 2002, 10-16.

MÁRQUEZ, Patricia; REFICCO, Ezequiel; BERGER, Gabriel. Socially Inclusive Business: Engaging the Poor through Market Initiatives in Iberoamerica. Cambridge, Massachusetts: Harvard University Press, 2010.

MELLO, Carlos Henrique Pereira.; TURRIONI, João Batista; XAVIER, Amanda Fernandes; CAMPOS, Danielle Fernandes. Pesquisa-ação na engenharia de produção: proposta de estruturação para sua condução. Produção, 2012, p. 1-13.

MOORE, James E. The death of competition: leadership and strategy in the age of business ecosystems. Nova York: Harper Business, 1996. 
MORRIS, Michael; MINET, Schindehutte; RICHARDSON, James; ALLEN, Jeffrey. Is the business model a useful strategic concept? Conceptual, theoretical, and empirical insights. Journal of Small Business Strategy, 2006, 27-50.

NVCA. Yearbook 2016: National Venture Capital Association. Washington, DC: Thompson Reuters, 2016.

ONU. Relatório do Desenvolvimento Humano. Nova York: PNUD, 2014.

OSTERWALDER, Alexander; PIGNEUR, Yves. Business Model Generation: A Handbook For Visionaries, Game Changers, And Challengers. Hoboken: John Wiley \& Sons, 2010.

PEDROSO, Marcelo Caldeira. Modelo de negócios e suas aplicações em administração. São Paulo, São Paulo: Faculdade de Economia, Administração e Contrabilidade, Universidade de São Paulo, 2016.

PEREDO, Ana Maria; MCLEAN, Murdith. Social entrepreneurship: a critical review of the concept. Journal of World Business 41, 2006, 56-65.

PETRINI, Maira; SCHERER, Patrícia; BACK, Léa. Modelo de negócios com impacto social. Revista da Administração de Empresas, 2016, 209-225.

PINTO, João Bosco Guedes. Pesquisa-ação: detalhamento de sua sequência metodológica. Recife: Mimeo, 1989.

PORTER, Michael; KRAMER, Mark. Creating Shared Value. Harvard Business Review, 2011, 17.

PRIEM, Richard L. A Consumer Perspective on Value Creation. Academy of Management, 2007, 219-235.

RAMALHO, Caio. Fostering Innovation in Brazil Through Private Equity and Venture Capital Public Policies. Procedings of the 5th European Conference on Innovation and Entrepreneurship. Atenas: National and Kapodistrian University of Athens, 2010, 461-471.

RANGAN, V. Kasturi et al. Business solutions for the global porr: creating social and economic value. San Francisco: Jossey-Bass, 2007.

RIDLING, Phil, FOWELL, Sue, LEVY, Phil. An action research approach to curriculum development. Information Research: An International Electronic Journal, 1995, 1.

RIES, Eric. The Lean Startup: How Today's Entrepreneurs Use Continuous Innovation to Create Radically Successful Businesses. Crown Publishing Group, 2011.

ROSOLEN, Talita; TISCOSKI, Gabriela Pelegrini; COMINI, Graziella Maria. Empreendedorismo social e negócios sociais: um estudo bibliométrico da publicação nacional e internacional. Revista Interdisciplinar de Gestão Social, 2014, 85-105. 
SCARLATA, Mariarosa; ZACHARAKIS, Andrew; WALSKE, Jennifer. The Effect of Founder Experience on the Performance of Philantropic Venture Capital Firms. International Small Business Journal, 2015, 618-636.

SEELOS, Christian; MAIR, Johanna. Social entrepreneurship: Creating new business models to serve the poor. Business Horizons 48, 2005, 241-246.

SENADO Federal. agosto 10, 2015. Disponível em:

$<$ http://www12.senado.leg.br/noticias/materias/2015/08/10/vanessa-grazziotin-lamentadeficit-de-3-milhoes-de-vagas-em-creches>. Acesso em: 12 mar. 2016

SHAFER, Scott M., SMITH, H. Jeff, LINDER, Jane C. The power of business models. Business Horizons, 2005, 199-207.

SOCIAL Lean Canvas. Social Lean Canvas. Social Lean Canvas. 2017. Disponível em: $<$ https://socialleancanvas.com/pdf/SocialLeanCanvas.v1.0.6.pdf $>$. Acesso em: 10 mar. 2017.

STANFORD. Sehub. Social Enterpreneurship Hub. 2017. Disponível em:

$<$ https://sehub.stanford.edu/sites/default/files/Social\%20Business\%20Model\%20Canvas_1.pd f>. Acesso em: 11 mar. 2017.

TANDEMIC. Social Business Model Canvas. Social Business Model Canvas. 2017. Disponível em: < http://www.socialbusinessmodelcanvas.com/wp-content/uploads/SBMCv2.png>. Acesso em: 11 mar. 2017.

TELLES, Renato. A efetividade da matriz de amarração de Mazzon nas pesquisas em Administração. Revista de Administração 36 (out./dez. 2001) 64-72.

TEODÓSIO, Armindo S. S.; COMINI, Graziella. Inclusive business and poverty: prospects in the Brazilian context. Revista de Administração, 2012, 410-421.

THIOLLENT, Michel. Metodologia da pesquisa-ação. São Paulo: Cortez, 2008.

TREXLER, Jeff. Social Entrepreneurship as an Algorithm: is Social Enterprise Sustainable? E:CO 10, n. 3, 2008, 65-85.

UNITED Nations Development Programme. Creating Value for All: Strategies for Doing Business with the Poor. Nova York: United Nations Development Programme, 2008.

VOELPEL, Sven C.; LEILBOLD, Marius; TEKIE, Eden B. The wheel of business model reinvention: How to reshape your business model to leapfrog competitors. Journal of Change Management, 2004, 259-276.

WEERAWARDENA, Jay; MORT, Gillian Sullivan. Investigating social entrepreneurship: a multidimensional model. Journal of World Business 41, 2006, 21-35.

WIRTZ, Bernd W.; GÖTTEL, Vincent. Business Models: Origin, Development and Future Research Perspectives. Long Range Planning, 2016, 36-54.

YIN, Robert K. Estudo de Caso. 5. Porto Alegre: Bookman, 2015. 
YUNUS, Muhammad. Creating a World Without Poverty. Nova York: PublicAffairs, 2007.

ZOTT, Christoph; AMIT, Raphael; MASSA, Lorenzo. The Business Model: Recent Developments and Future Research. Journal of Management, 2011, 1019-1042. 


\section{APÊNDICES}

APÊNDICE A - Roteiro para entrevista semiestruturada com Danone

Entrevistado:

Empresa:

Data:

\section{Questões a serem cobertas na entrevista:}

1. Como nasceu o projeto Kiteiras?

2. Quem o financia?

3. Qual é o perfil da kiteira?

4. Qual a lógica econômica do projeto?

5. Como é feita a gestão do projeto?

6. Como foi o processo de construção de rede de mulheres nas comunidades?

7. Como funciona a comunicação com essas mulheres?

8. Como mensuram impacto social?

9. Quais são os resultados alcançados?

10. Quais foram as principais dificuldades encontradas?

11. Quais foram as soluções encontradas para tais dificuldades?

12. Quem são os parceiros-chave?

13. Como é a relação financeira com tais parceiros? 
APÊNDICE B - Roteiro para entrevista semiestruturada com Visão Mundial

Entrevistado:

Empresa:

Data:

\section{Questões a serem cobertas na entrevista:}

1. Como nasceu a pareceria com a Danone?

2. Qual é o papel da Visão Mundial no Kiteiras?

3. Como a Visão Mundial se conecta com as mulheres nas comunidades?

4. Como a Visão Mundial se relaciona com as lideranças locais?

5. Qual o benefício social entregue pelo projeto?

6. Qual é a contribuição do Kiteiras à Visão Munidal? 


\section{ANEXOS}

ANEXO A - Elementos visuais utilizados na elucidação sobre o modelo de negócios

Confira na integra como tudo funciona

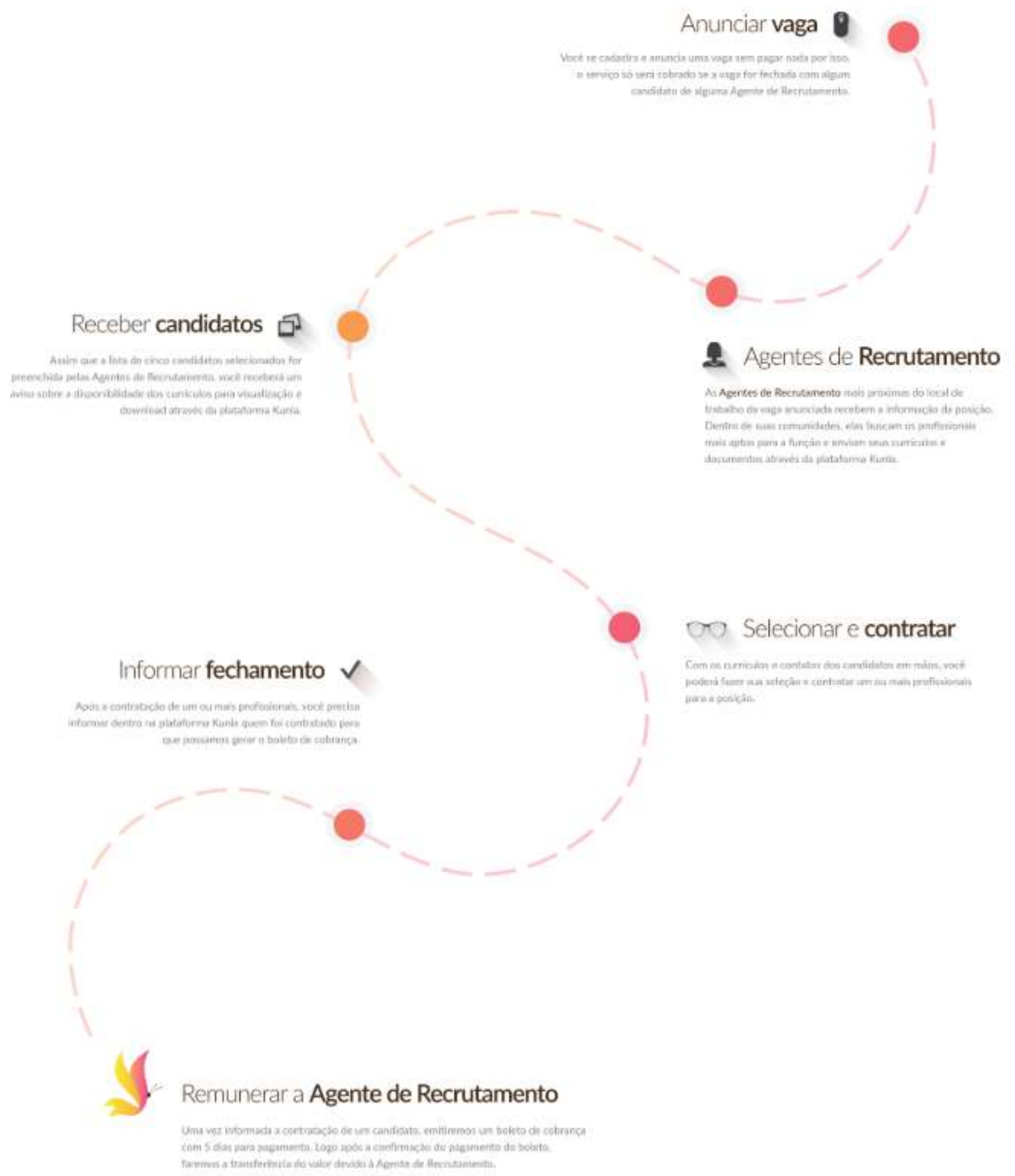




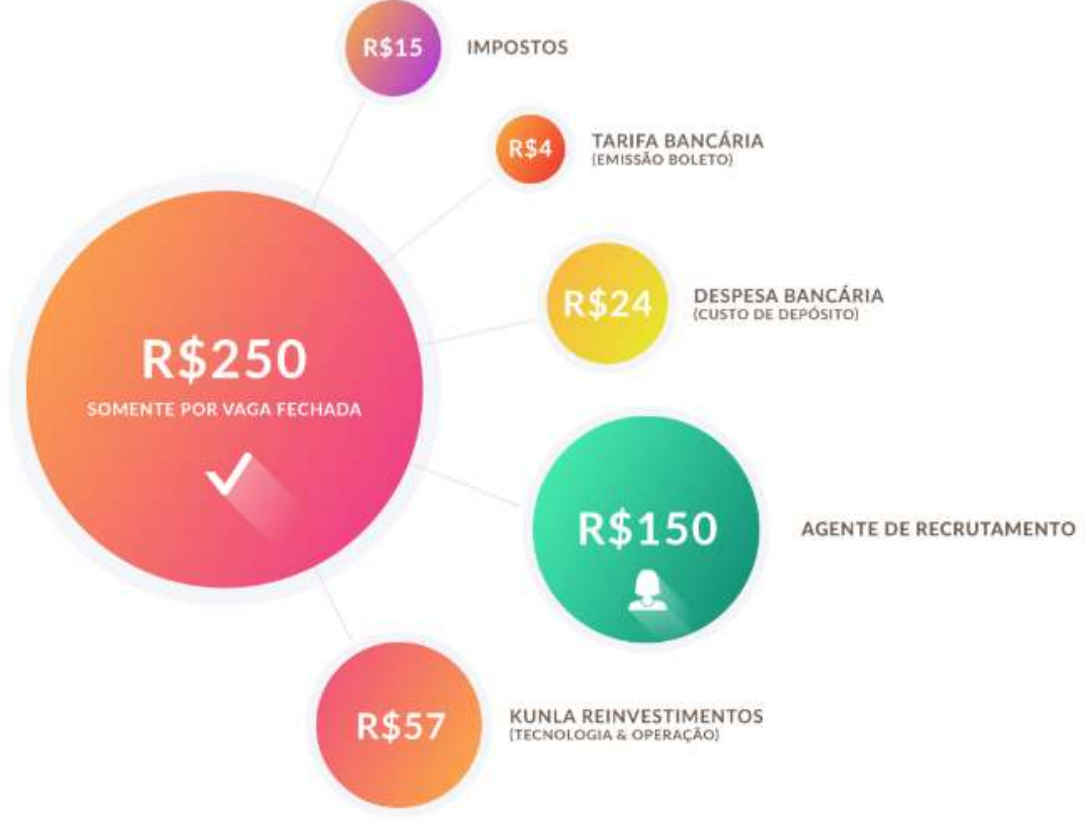


ANEXO B - Reportagem foi veiculada no Projeto Draft

DAAFT

SEĈ̣̄ES Nós MISSÃO NEWSLETIER CONTATO MEDIA KIT MANIFESTO

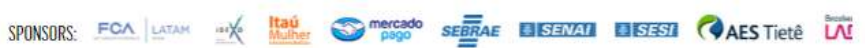

USANDO O WHATSAPP, A KUNLA É UM NEGÓCIO SOCIAL QUE GERA RENDA PARA MÄES COMM FILHOS PEQUENOS E SEM CRECHE

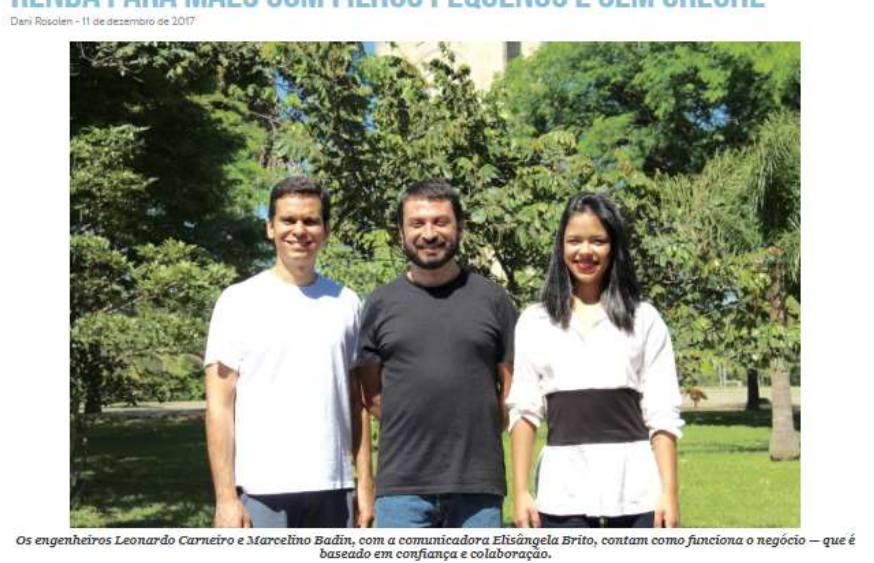

Compartihar:

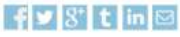

A Kunla Social pode até parecer apenas uma agência de recrutamento, mas é muito mais que isso: é um negócio social que atua em rede para provocar impacto positivo em (pelo menos) dois elos enquanto faz o recrutamento em si. Na Kunla, mulheres com filhos pequenos, moradoras de comunidades carentes, são treinadas para trabalharem como agentes recrutadoras e são elas as responsáveis por encontrar o candidato buscado, sempre no bairro em que moram. A cada contratação realizada, ganham 150 reais (dos 250 que a empresa contratante paga a Kunla). 0 trabaho de rede reflete a origem do nome do negocio, uma abreviação da palavra kumlabori, que significa colaborar em esperanto.

A startup acaba de ser selecionada para aceleração na Estaçăo Hack, a recém-lançada actelera projeto 0 mestrado de Empreendedorismo, na USP, identificou o problema social da falta de creches e vulnerabilidade dessas mulheres), somado ao conhecimento tecnológico do seu amigo e engenheiro elétrico Marcelino Badin, 39.0 primeiro, de Goiânia, e o segundo, de Campinas (SP), moraram juntos em uma república em São Carlos, no interior paulista, durante a faculdade. A amizade seguiu enquanto ambos começaram suas carreiras, relativamente convencionais, no mundo corporativo, até que perceberam que ambos viviam um momento de questionamento semelhantes - quando a ideia da startup surgiu.

QUANDO EMPREENDER POR EMPREENDER NÃO BASTA

Leonardo era fundador de uma empresa de recrutamento executivo. Em 2014, após uma baixa no número de clientes por causa da crise, resolveu apostar em outra demanda: encontrar candidatos para posicões operacionais (a saber, cargos em que não é preciso ter curso superior e os salários são geralmente mais baixos, tais como faxineiro, pintor, balconista, porteiro etc). Fechou o antigo negócio e abriu outro com foco em vagas operacionais, mas para PCD - sigla de Pessoa com Deficiência, usada para se referir a quem tem limitaçoes permanentes como deficiência visual, auditiva, fisica ou intelectual. Mesmo assim, ele ainda não estava contente:

"Era algo só para ganhar dinheiro.

Logo que me dei conta, passei a pensar em alternativas e surgiu a ideia de ajudar mães com filhos sem creches a terem renda"

Foi, então, que começou a rascunhar o projeto da Kunla. Para Marcelino, o sentimento era o mesmo. Ele empreendeu antes da faculdade desenvolvendo sites de e-commerces. Depois de formado e de ter trabalhado em consultorias, como a Accenture, sentiu novamente a vontad de seguir uma carreira mais independente. Chegou a largar o emprego para criar um produto tecnológico, que mapeava as preferêncías dos clientes de acordo com seu deslocamento geográfico, mas ainda sentia falta de "algo mais".

Os dois somaram esforços, coragem e um aporte de 200 mil reais (vindo de economias pessoais) para, em junho deste ano, abrirem o negócio. Mesmo com pouco tempo de operação, a Kunla já conseguiu chamar a atenção de algumas centenas mães em mais de 50 comunidades da Grande São Paulo. Nem todas estão ativas na plataforma, mas os primeiros passos foram dados e, pouco a pouco, o impacto e o faturamento da startup aumentam. A operação começo em outubro e a previsão é fechar o ano com 30 mil reais de faturamento, além de ter a equipe estabelecida em um escritório próprio na Sé, no centro da capital paulista. 
COMO FUNCIONA

Uma consultora da Kunla visita as comunidades em busca de mães interessadas em serem agentes recrutadoras. Elas passam a receber os anúncios de vagas diariamente por meio do Whatsapp. Os postos são sempre específicos para a região onde moram (para evitar que abandonem 0 emprego por conta da dificuldade de deslocamento). Assim que recebem os
anúncios, as mães tentam encontrar dentro de suas comunidades pessoas com o perfil buscado.

O modelo é bem simples, não precisa de acesso a computador, apenas um celular com internet (a maioria usa wifi mesmo). A Kunla está desenvolvendo um sistema que simplifique esse processo, mas por enquanto, elas tiram fotos dos $\mathrm{CVs}$ dos candidatos que selecionaram $\mathrm{e}$ mandam por mensagem para uma consultora da startup, que faz a triagem de até dez pesso por vaga. A empresa contratante paga 250 reais para a Kunla apenas se ficar com um dos
candidatos sugeridos. Deste valor, 150 reais são repassados para a mãe que fez a seleção.

Hoje a Kunla tem ao todo 700 mães cadastradas de diversas comunidades da capital paulista $e$ Grande São Paulo (Heliópolis, Taipas, Utinga e Jardim Nazaré, por exemplo), mais de 200 vagas oferecidas por três empresas clientes. Em abril do ano que vem, eles pretendem buscar investimento para tração e escalar em 2019.

UM NEGÓCIO SOCLAL VOLTADO PARA MÃES

Os sócios sempre são questionados do por que escolheram mães como alvo do negócio social. Não é dificil deduzir que uma mulher sem acesso a uma creche tem que ficar em casa para cuidar das crianças e acaba se tornando financeiramente dependente de alguém. "Quando isso acontece, vimos que a qualquer custo. Năo importa ao que ela ou a criança serão submetidas", diz Leonardo.

Uma pesquisa do IBGE, de 2015, usada pelos empreendedores como referência, indicava que, na época, existiam 10,5 milhões de crianças entre o e 4 anos de idade no Brasil. Destas, $75 \%$ eram cuidadas pelo responsável que, em quase $90 \%$ dos casos, era do gênero feminino. Somese a isso o déficit do número de vagas em creches: 75 mil, apenas na cidade de São Paulo.

Apesar de ter como foco essas mães, os fundadores contam que o impacto positivo recai sobre toda a família envolvida. E claro, como toda regra, sempre existem exceçôes. "Tivemos uma avó como agente recrutadora, pois era ela quem ficava em casa cuidando do neto enquanto a filha trabalhava. E outro de uma mãe com um filho de mais idade, mas com deficiência", conta Marcelino.

COMO ENCONTRAR AS PESSOAS QUE SEU NEGÓCIO VAI BENEFICIAR

Com o público definido, o desafio dos empreendedores era correr atrás dessas mães. A tarefa foi facilitada pela contratação de Antônia Ribeiro como consultora da Kunla. Assistente social, ela já havia trabalhado cadastrando familias carentes para receber benefícios sociais de politicas públicas. “Antônia é nossa mensageira. Ela conversa com uma líder comunitária para ter acesso às mulheres, explica o funcionamento da plataforma, faz reuniões, distribui panfletos", conta Marcelino.

Mesmo com experiência em campo, a consultora enfrentou empecilhos no começo da operação. "Tivemos casos de líderes falarem que iam ficar com metade do que pagávamos às mães, apenas para liberar nossa entrada na comunidade", diz o empreendedor. 0 problema fez com que eles repensassem a maneira de vender a proposta. Agora, Antônia vai às comunidades uniformizada, com um discurso "bastante claro" e, contam, isso ajudou a romper essa barreir muitas vezes, Antônia é guiada pelas próprias moradoras que querem participar do projeto.

Depois da fase de captação, entra em cena a assistente de comunicação Elisângela Brito, assistente de comunicaçao Ellsangela Bito,

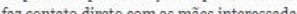
faz contato direto com as mäes interessadas para evplicar mass uma ver com finciona quais os beneficios. Essa troca de mensagens, a distribuiç̃o dos anúncios de ragas e envio dos currílos dos candidos pelas agentes são feitos via Whatsapp

Elisângela envia para cada uma as propostas de vagas para 0 bairro em que as mãesrecrutadoras residem. $\mathrm{A}$ partir dai, as mulheres devem achar a pessoa certa para a posição. Este processo dura, em média, cinco semanas, dizem os sócios.

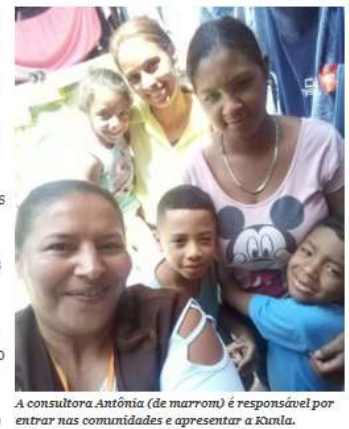

Marcelino conta que, assim como o modo

apresentar a Kunla, os anúncios também

tiveram que ser repensados para funcionar melhor. "Elas nos pediram dados mais práticos, como grau de experiencia, horário de trabalho e salario que o profissional vai receber", conta. Outra questào, diz, foi faze--las entender que as vagas com requisitos PCD eram como todas as outras: as mães só deveriam identificar onde estava esse potencial candidato (que hoje em dia procurado em instituiçôes de apoio próximas às comunidades).

PROJETO NA RUA É PROJETO SENDO REAJUSTADO. SEMPRE

Ter um projeto social no papel é bonito, tudo parece perfeito. Basta colocá-lo na rua para que a realidade se encarregue de desconstruir o sonho. Para Leonardo e Marcelino não foi diferente. "No começo, tinham maes que se apegavam ao candidato, pois tinham um amigo precisando emprego e o colocavam em todas as vagas", conta Marcelino, e prossegue: "Ou, então, elas simplesmente po nenhuma seleção"

Era preciso melhorar isso e, novamente, coube à assistente de comunicação Elisângela reforça: a mensagem $e$ o diferencial da Kunla, para fazer as mães compreenderem que era responsabilidade delas encontrar a pessoa adequada se quisessem fechar uma vaga e receber o pagamento. Por conta disso, a Kunla estabelecen o limite de envio de três currículos por vaga

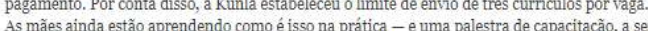
proferida por uma agente considerada exemplo na plataforma da Kunla, está marcada para próximos meses. 
O PODER DO WHATSAPP NAS COMUNIDADES

As empresas interessadas em contratar candidatos para vagas operacionais têm como enviar seus anuncios pela plataforma digital da Kunla. Mas o contato com as agentes foi montado todo com dase no hatsapp. Isso logo deve evoluir, pois Marcelno trabaha no desenvolvimento de receber vagas "personalizadas” (de acordo com seu ranking de desempenho, por evenplo).

0 acesso à internet para manter a comunicação com as agentes recrutadoras não foi um grande problema pois, segundo os sócios, a maioria consegue conexão wi-fi em centros comunitários. O que ainda serve de impeditivo, porém, é a falta de um smartphone. Assim como algumas mães estão negativadas e preferem ser remuneradas sem transação bancária (o que é um desafio para a Kunla), o aparelho deve estar no nome da mãe. "Senão, fica aquele negócio de emprestimo e, no final, os 150 reais que serviriam para comida ou remédio podem virar uma taxa de aluguel do celular de um terceiro", diz Leonardo. Para resolver a questão, a dupla planeja realizar uma campanha de doação de aparelhos.

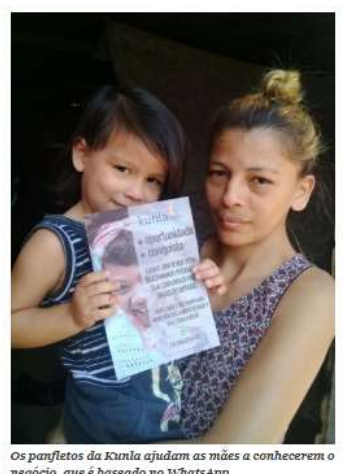

imediato, os empreendedores querem mais demanda. Com a operaçăo estrutura e a parte tecnologica encaminhada, 0 objetivo é correr atrás de novos cliente.

Hoje em dia a Kunla tem três: a agência de recrutamento PcD do próprio Leonardo, um restaurante de Pinheiros, na zona oeste da cidade, a Danone (parcena recem chama as pessoas rendemes marca de porta em porta, na região do $A B C$ paulista). Juntos, os trê, na regláo do ABC oferecem para a plataforma pouco mis (200 vages

Onumero ainda é baixo. Para tentar amplì esse porttólio, os sócios apostaram na contratação de mais três funcionários (doit de vendas e uma nova consultora), aumentaram o investimento em negocio, que é basseado no whatsapp. marketing. Eles son vezes maior, o que permitiria a cada mãe fechar, pelo menos, dez candidatos por mês, recebendo o equivalente a uma renda de 1500 reais.

Além disso, querem extrapolar a atuação da Kunla. Segundo Leonardo, uma agência de recrutamento e seleção cobra cerca de 600 reais para conseguir um candidato. "Como a noss operação é mais enxuta, ágil e de custo menor, uma empresa que não teria condiçôes de paga por esse serviço poderia usar a Kunla". A expansão territorial também e cogitada. Os socios ja receberam mensagens de interessados do Norte e Nordeste do país, mas dependem da escal

Marcelino, que se dedica em tempo integral à startup, admite que hoje tem mais sobrecarga de trabalho do que quando era consultor, mas diz que se sente mais leve: "A Kunla é um negócio ar sobre esse projeto, não é a mesma coisa que explicar códigos e programação para alguém." O enfoque social amoleceu a racionalidade do engenheiro, que lembra da emoção que sentiu ao fazer o primeiro pagamento a uma agente:

"Ela disse que com o dinheiro completaria o aluguel da casa. Comecei a chorar e senti que, pela primeira vez tinha impactado a vida de uma pessoa de imediato"

Para Leonardo, a transformação foi mais gradativa. Ele não está na Kunla em tempo integral e acredita que a startup e uma somatoria ce suas experlencias na busca por propósito, além de ser tambem um desafio de persistencia. Ele diz que ouviu varias vezes que era doido. Primeiro, quando decidiu largar o emprego fixo para começar a empresa de recrutamento executivo. Depois, ao fechá-la e, na sequência, abrir outra com foco operacional. Por fim, quando apostou em um negócio social prometendo gerar retorno financeiro. "A partir do momento que a Kunla comecou a rodar, ficou provado que não sou louco. 0 projeto não é uma viagem, romantisn

DRAFT CARD
- Projeto: Kunla Social
- o que faz: Agência de recrutamento
- Sócio(s): Leonardo Cameiro e Marcelino Badin
- Funcionários: 7 (incluindo os sócios)
- Sede: Săo Paulo
- Ińcio das atividades: Junho de 2017
- Investimento inicial: $\mathbb{R} \$ 200$ mil
- Faturamento: $\mathrm{R} \$ 30$ mil (em três meses de operação)
- Contato: kunla@kunla. Social

